Nevada

Environmental

Restoration

Project

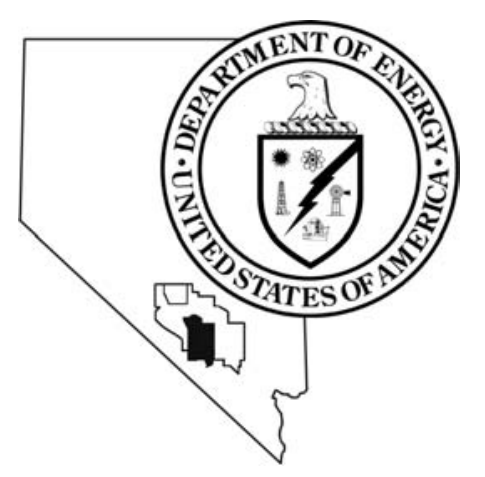

Corrective Action Investigation Plan

for Corrective Action Unit 34:

Area 3 Contaminated W aste Sites

Nevada Test Site, Nevada

Controlled Copy No.:

Revision No.: 0

March 2001

Approved for public release; further dissemination unlimited.

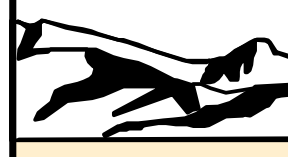

Environmental Restoration

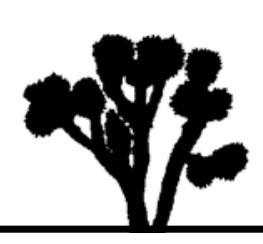

Division 
Available for public sale, in paper, from:

U.S. Department of Commerce

National Technology Information Service

5285 Port Royal Road

Springfield, VA 22161

Phone: 800.553 .6847

Fax: 703.605.6900

Email: orders@ntis.fedworld.gov

Online ordering: http://www.ntis.gov/ordering.htm

Available electronically at http://www.doe.gov/bridge.

Available for a processing fee to U.S. Department of Energy and its contractors, in paper, from:

U.S. Department of Energy

Office of Scientific and Technical Information

P.O. Box 62

Oak Ridge, TN 37831-0062

Phone: 865.576 .8401

Fax: 865.576.5728

Email: reports@adonis.osti.gov

Reference herein to any specific commercial product, process, or service by trade name, trademark, manufacturer, or otherwise, does not necessarily constitute or imply its endorsement, recommendation, or favoring by the United States Government or any agency thereof or its contractors or subcontractors. 


\title{
CORRECTIVE ACTION INVESTIGATION PLAN FOR CORRECTIVE ACTION UNIT 34: AREA 3 CONTAMINATED WASTE SITES NEVADA TEST SITE, NEVADA
}

\author{
DOE Nevada Operations Office
}

Las Vegas, Nevada

Controlled Copy No.:

Revision No.: 0

March 2001

Approved for public release; further dissemination unlimited. 


\section{CORRECTIVE ACTION INVESTIGATION PLAN \\ FOR CORRECTIVE ACTION UNIT 34: \\ AREA 3 CONTAMINATED WASTE SITES NEVADA TEST SITE, NEVADA}

Approved by:

Date: $\quad 3 / 27 / 01$

Janet Appenzeller-Wing, Project Manager

Industrial Sites Project

Approved by:

Date:

$3 / 27 / 01$

Runore C. Wycoff, Division Director

Environmental Restoration Division 


\section{Table of Contents}

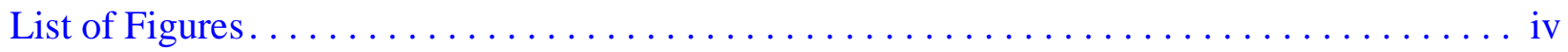

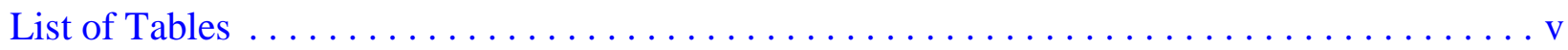

List of Acronyms and Abbreviations $\ldots \ldots \ldots \ldots \ldots \ldots \ldots \ldots \ldots \ldots \ldots \ldots \ldots \ldots$

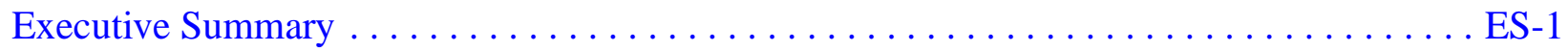

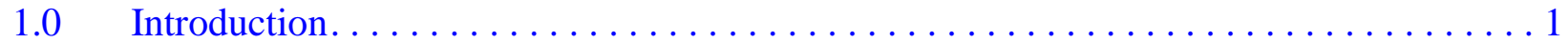

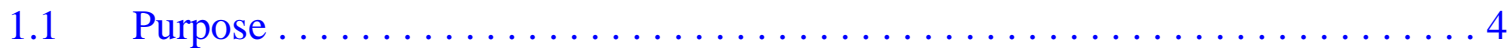

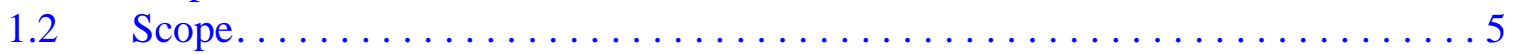

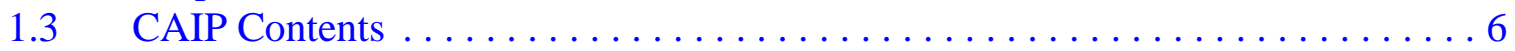

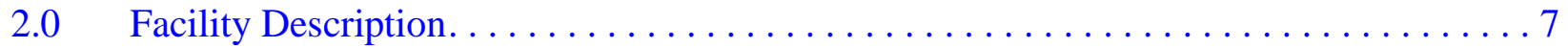

2.1 Physical Setting. . . . . . . . . . . . . . . .

2.2 Operational History. . . . . . . . . . . . . . . . . . 7

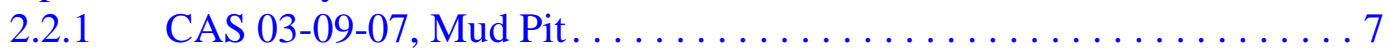

2.2.2 CAS 03-44-01, Chromium Contamination Spill . . . . . . . . . . . . 9

2.2.3 CAS 03-47-02, Area 3 Mud Plant Pond ................... 9

2.2.4 CAS 03-09-06, Mud Disposal Crater . . . . . . . . . . . . . 10

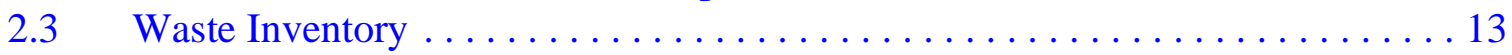

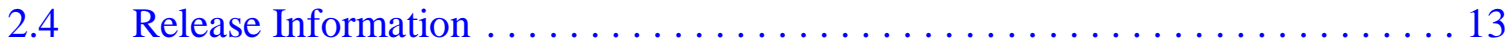

2.4.1 CAS 03-09-07, Mud Pit..................... 13

2.4.2 CAS 03-44-01, Chromium Contamination Spill . . . . . . . . . . . . 15

2.4.3 CAS 03-47-02, Area 3 Mud Plant Pond ................. 16

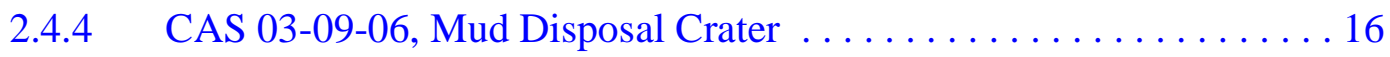

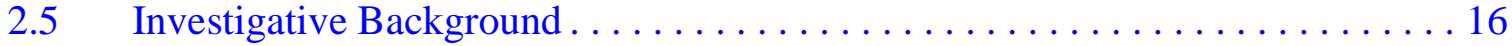

2.5.1 CAS 03-09-07, Mud Pit.................... 16

2.5.2 CAS 03-44-01, Chromium Contamination Spill . . . . . . . . . . . 17

2.5.3 CAS 03-47-02, Area 3 Mud Plant Pond ................ 17

2.5.4 CAS 03-09-06, Mud Disposal Crater .................. 18

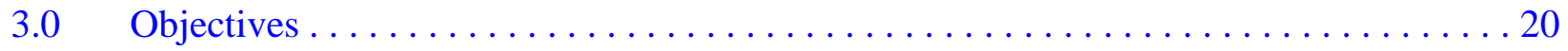

3.1 Conceptual Site Model . . . . . . . . . . . . . . . . . . . . 20

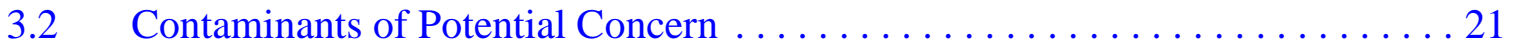

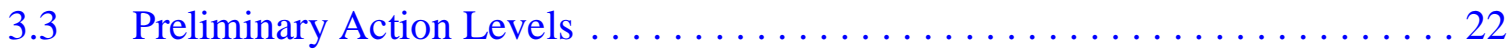

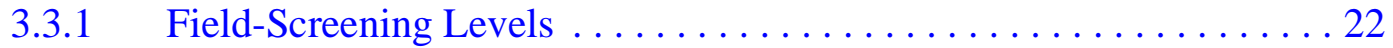

3.3.2 Chemical Preliminary Action Levels. . . . . . . . . . . . . . . 23

3.3.3 Radiological Preliminary Action Levels ................. 23

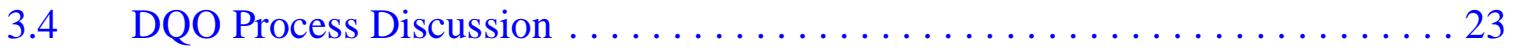




\section{Table of Contents (Continued)}

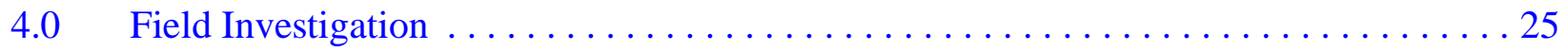

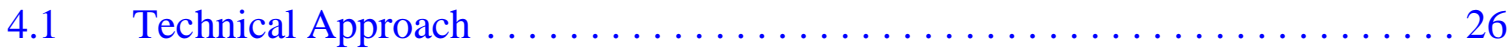

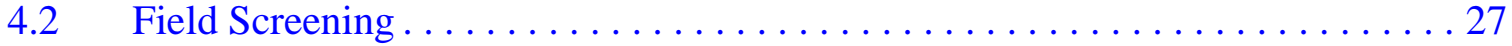

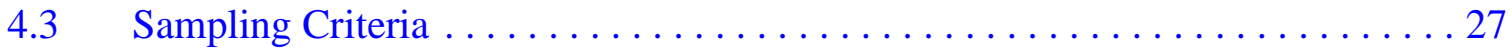

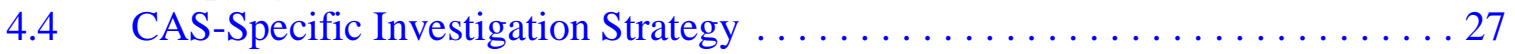

4.4.1 CAS 03-09-07, Mud Pit...................... 28

4.4.2 CAS 03-44-01, Chromium Contamination Spill . . . . . . . . . . . 28

4.4.3 CAS 03-47-02, Area 3 Mud Plant Pond . . . . . . . . . . . . . . . . . . 29

4.4.4 CAS 03-09-06, Mud Disposal Crater . . . . . . . . . . . . . . . . 29

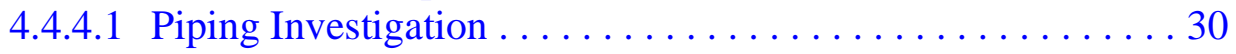

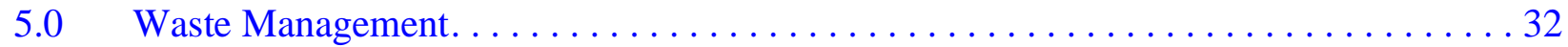

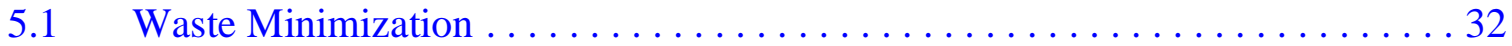

5.2 Potential Waste Streams . . . . . . . . . . . . . . . . . . . 33

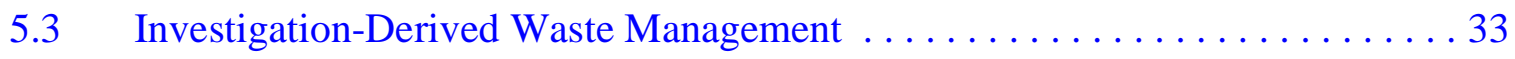

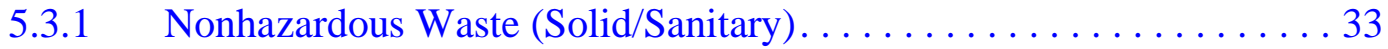

5.3.2 Hydrocarbon Waste . . . . . . . . . . . . . . . . . . 33

5.3 .3 Hazardous Waste . . . . . . . . . . . . . . . . . . . . . . . 34

5.3 .4 Low-Level Radioactive Waste. . . . . . . . . . . . . . . . 35

$5.3 .5 \quad$ Mixed Waste . . . . . . . . . . . . . . . . . . 36

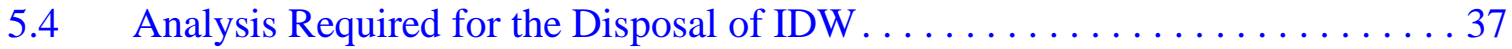

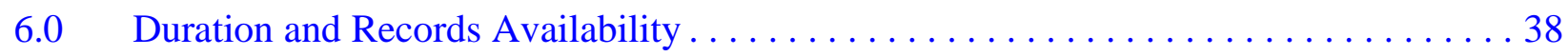

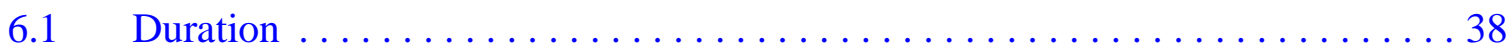

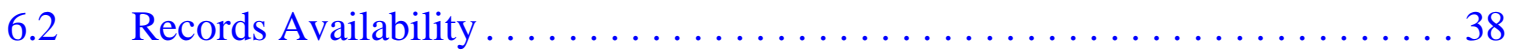

$7.0 \quad$ References........................................... 39

\section{Appendix A - Data Quality Objectives Worksheets}

A.1.0 Introduction $\ldots \ldots \ldots \ldots \ldots \ldots \ldots \ldots \ldots \ldots \ldots \ldots \ldots \ldots \ldots \ldots \ldots \ldots \ldots \ldots$

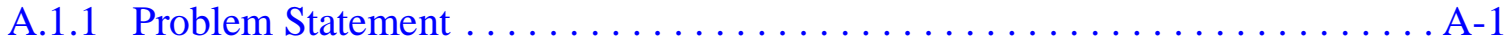

A.1.2 DQO Meeting .............................. A-3

A.2.0 Conceptual Model. . . . . . . . . . . . . . . . . . . . . . . A-4

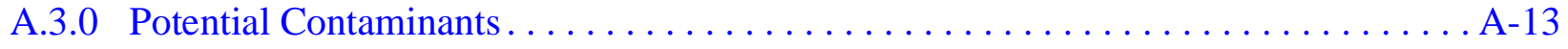

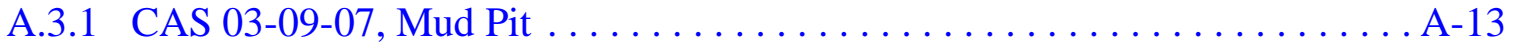

A.3.2 CAS 03-44-01, Chromium Contamination Spill . . . . . . . . . . . . . A-13

A.3.3 CAS 03-47-02, Area 3 Mud Plant Pond . . . . . . . . . . . . . . . . . . . A-14

A.3.4 CAS 03-09-06, Mud Disposal Crater . . . . . . . . . . . . . . . A-14 


\section{Table of Contents (Continued)}

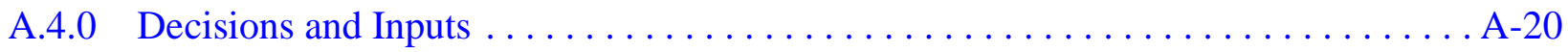

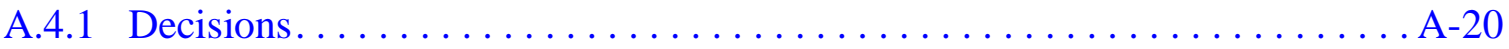

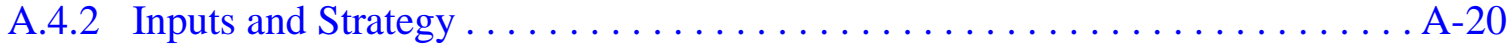

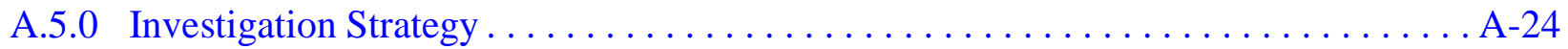

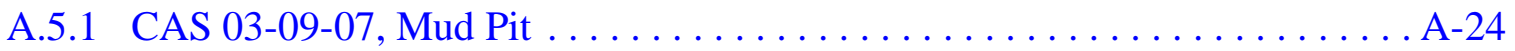

A.5.2 CAS 03-44-01, Chromium Contamination Spill . . . . . . . . . . . . . . A-25

A.5.3 CAS 03-47-02, Area 3 Mud Plant Pond ................... A-25

A.5.4 CAS 03-09-06, Mud Disposal Crater . . . . . . . . . . . . . . . . A-25

A.6.0 Decision Rules . . . . . . . . . . . . . . . . . . . . . . A-27

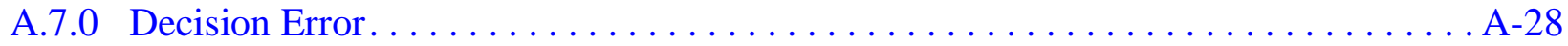

A.8.0 References.................................... A-31

Appendix B - Project Organization

B.1.0 Project Organization $\ldots \ldots \ldots \ldots \ldots \ldots \ldots \ldots \ldots \ldots \ldots \ldots \ldots \ldots \ldots \ldots \ldots \ldots \ldots \ldots \ldots \ldots$

Appendix C - Laboratory Chemical, Toxicity Characteristic Leaching Procedure, and Radiochemistry Analytical Requirements for Industrial Sites

C.1.0 References................................ 


\section{List of Figures}

Number

1-1 Nevada Test Site, Nye County, Nevada . . . . . . . . . . . . . . . 2

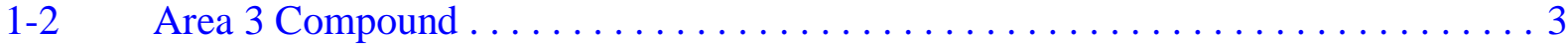

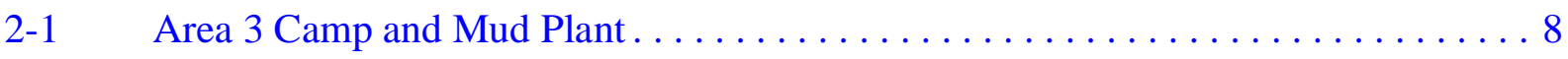

2-2 Aerial Photograph of Area 3 Mud Plant Compound taken September 23, 1989 . . . 11

A.2-1 CAS 03-09-07, Mud Pit Diagrammatic Sketch................. A-5

A.2-2 CAS 03-44-01, Chromium Contamination Spill Diagrammatic Sketch . . . . . . A-6

A.2-3 CAS 03-47-02, Mud Plant Pond Diagrammatic Sketch . . . . . . . . . . A-7

A.2-4 CAS 03-09-06, Mud Disposal Crater Diagrammatic Sketch . . . . . . . . . . A A-8 


\section{List of Tables}

Number

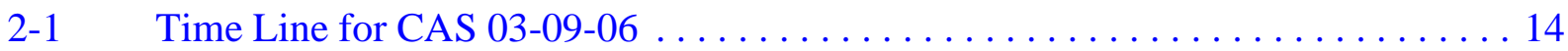

5-1 Waste Management Regulations and Requirements . . . . . . . . . . . . . 34

5-2 Analysis Required for the Disposal of IDW . . . . . . . . . . . 37

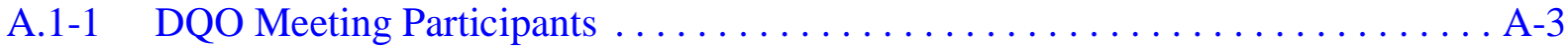

A.2-1 Conceptual Model for CAU 34, Areas 3 and 12 Contaminated Waste Sites ..... A-9

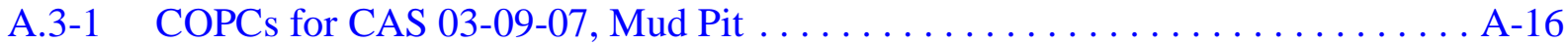

A.3-2 COPCs for CAS 03-44-01, Chromium Contamination Spill . . . . . . . . . A-17

A.3-3 COPCs for CAS 03-47-02, Mud Plant Pond . . . . . . . . . . . . A-18

A.3-4 COPCs for CAS 03-09-06, Mud Disposal Crater . . . . . . . . . . . . . . A-19

A.4-1 Decisions, Inputs, and General Strategies . . . . . . . . . . . . . . A-21

A.7-1 Average Coefficient of Variation (CV) for SW-846 Methods . . . . . . . . . . A-29

A.7-2 Expected Percent Error with Gridded Sampling Pattern . . . . . . . . . . . . . A-29

C.1-1 Laboratory Chemical, Toxicity Characteristic Leaching Procedure, and Radiochemistry Analytical Requirements for Industrial Sites 


\section{List of Acronyms and Abbreviations}

bgs Below ground surface

CADD Corrective Action Decision Document

CAIP Corrective Action Investigation Plan

CAS Corrective Action Site

CAU Corrective Action Unit

CERCLA Comprehensive Environmental Response Compensation and Liability Act

CFR Code of Federal Regulations

Co-60 Cobalt-60

COPC Contaminant(s) of potential concern

CV Coefficient of Variation

DOE U.S. Department of Energy

DOE/NV U.S. Department of Energy, Nevada Operations Office

DOT U.S. Department of Transportation

dpm Disintegration(s) per minute

DQO Data Quality Objective

EPA U.S. Environmental Protection Agency

Eu-152 Europium-152

Eu-154 Europium-154

Eu-155 Europium-155

FFACO Federal Facility Agreement and Consent Order

FSL Field-screening level

FSR Field-screening results

$\mathrm{ft} \quad$ Foot (feet)

GPR Ground-Penetrating Radar

HASP Health and Safety Plan

HWAA Hazardous waste accumulation area 


\section{List of Acronyms and Abbreviations (Continued)}

$\begin{array}{ll}\text { IDW } & \text { Investigation-derived waste } \\ \text { in. } & \text { Inch(es) } \\ \text { ISMS } & \text { Integrated Safety Management System } \\ \text { ITLV } & \text { IT Corporation, Las Vegas Office } \\ \text { LLW } & \text { Low-level radioactive waste } \\ \text { mg/kg } & \text { Milligram(s) per kilogram } \\ \text { mi } & \text { Mile(s) } \\ \text { NAC } & \text { Nevada Administrative Code } \\ \text { NDEP } & \text { Nevada Division of Environmental Protection } \\ \text { NTS } & \text { Nevada Test Site } \\ \text { NTSWAC } & \text { Nevada Test Site Waste Acceptance Criteria } \\ \text { PAL } & \text { Preliminary action level } \\ \text { PCBs } & \text { Polychlorinated Biphenyls } \\ \text { pCi/g } & \text { Picocurie(s) per gram } \\ \text { PPE } & \text { Personal protective equipment } \\ \text { ppm } & \text { Part(s) per million } \\ \text { PRG } & \text { Preliminary remediation goal } \\ \text { QA } & \text { Quality assurance } \\ \text { QAPP } & \text { Quality Assurance Project Plan } \\ \text { QC } & \text { Quality control } \\ \text { RCA } & \text { Radioactive Controlled Area } \\ \text { RCRA } & \text { Resource Conservation and Recovery Act } \\ \text { RAE } & \text { Radioactive Materials Area } \\ \text { RAccumulation Area }\end{array}$




\section{List of Acronyms and Abbreviations (Continued)}

SSL Soil-screening level

SVOC Semivolatile organic compound(s)

TCLP Toxicity Characteristic Leaching Procedure

TPH Total petroleum hydrocarbon(s)

UVF Ultraviolet fluorescence

VOC Volatile organic compound

$\mu \mathrm{Ci} / \mathrm{mL} \quad$ Microcurie(s) per mililiter 


\section{Executive Summary}

The Corrective Action Investigation Plan for Corrective Action Unit 34, Area 3 Contaminated Waste Site, has been developed in accordance with the Federal Facility Agreement and Consent Order that was agreed to by the U.S. Department of Energy, Nevada Operations Office, the State of Nevada Division of Environmental Protection, and the U.S. Department of Defense. Corrective Action Unit 34 consists of the following Corrective Action Sites (CASs):

- Corrective Action Site 03-09-07, Mud Pit

- Corrective Action Site 03-44-01, Chromium Contamination Spill

- Corrective Action Site 03-47-02, Area 3 Mud Plant Pond

- Corrective Action Site 03-09-06, Mud Disposal Crater

Unknown concentrations and volumes of hydrocarbons, chemical constituents, and radionuclides may have been released in surface and subsurface soils at the four CASs within this Corrective Action Unit. These releases were a result of mixing and storing drilling mud and fluids, disposal of used drilling mud, disposal (and spill at CAS 03-44-01, Chromium Contamination Spill) of mud additives, and disposal and run-off of potentially contaminated wastewater. Piping associated with CASs 03-47-02 and 03-09-06 may also be contaminated.

Corrective Action Site 03-09-07, Mud Pit, consists of a 245- by 315-foot (ft) fenced, bermed mud pit. It is located $250 \mathrm{ft}$ north of the U3gd crater and south of the Area $3 \mathrm{camp}$. In the northeast corner of the mud pit is an internal bermed pit approximately 100 by $40 \mathrm{ft}$ in size. Historical documentation reveals that the mud pit possibly received both pre- and post-shot drilling waste, and drill yard washings.

Corrective Action Site 03-44-01, Chromium Contamination Spill, consists of a 2-ft by 3-ft area located on the east side of the Mud Plant Building. The area is stained dark brown and consists of small, approximately 0.05 -inch (in.), chips which may be the chromium-containing materials. The source of the chromium spill was Raykrome 400, a drilling mud additive used in the Mud Plant Building.

Corrective Action Site 03-47-02, Area 3 Mud Plant Pond, consists of a freshwater pond approximately $205 \mathrm{ft}$ in diameter and is located approximately $47 \mathrm{ft}$ east of the Mud Plant Building. 
This CAS was a freshwater reservoir used for the formulation of mud at the Mud Plant Building. It is unknown whether this CAS also received effluent containing COPCs associated with the nearby Mud Plant Building. Historical evidence reveals that the pond began to dry up in the 1992 to 1993 time frame.

Corrective Action Site 03-09-06, Mud Disposal Crater, consists of the approximately 314-ft diameter, U-3ag subsidence crater. U-3ag was the site of the February 16, 1962, underground Chinchilla nuclear test. Following the test, the crater was used as a mixing and storage containment for drilling mud used throughout the NTS. After the completion of the Mud Plant, the crater was used for disposal receiving waste from Baker tanks, vacuum trucks, and the mud plant.

Based on the site history collected to support the Data Quality Objectives process, contaminants of potential concern include volatile organic compounds, semivolatile organic compounds, Resource Conservation and Recovery Act metals, petroleum hydrocarbons, gamma-emitting radionuclides, isotopic plutonium, and strontium-90. A conceptual site model for the Corrective Action Unit was developed and is summarized as follows:

- The contaminants of potential concern, if present, are associated with:

- Formulation (Corrective Action Site 03-47-02) and storage of drilling mud (Corrective Action Sites 03-09-07 and 03-09-06)

- Disposal of waste and used drilling mud and fluids (Corrective Action Sites 03-09-07 and 03-09-06)

- Unintentional release of mud additives (Corrective Action Site 03-44-01)

- Effluent discharge from drilling tanks and truck-washing activities (Corrective Action Site 03-09-06)

- Lateral contamination is not expected to exceed the historical boundaries of each corrective action site.

- Historical boundaries have been defined as the berms that extend along the perimeters of CAS 03-09-07, CAS 03-47-02, and CAS 03-09-06. The historical boundary of CAS 03-44-01 is defined as the perimeter of the stained area.

- Vertical migration of contamination, if present, will be limited based on the characteristics of the contamination, the low potential of migration through the media, and the absence of 
driving forces to facilitate migration at the mud pit, the chromium contamination spill, mud plant pond, and mud disposal crater.

- The geometry, depth, and contours of the Mud Disposal Crater are not fully known.

- The construction, geometry, and source(s) of the piping associated with CAS 03-47-02, Mud Plant Pond, and CAS 03-09-06, Mud Disposal Crater, are not fully known.

- Exposure pathways are ingestion, inhalation, and dermal contact.

- Groundwater impacts are not expected. Depth to groundwater is estimated at a depth of 1,610 ft below ground surface at the Area 3 Compound. Additionally, the environmental conditions at the site (e.g., arid climate, high evaporation) and the characteristics of the contamination are not conducive to downward migration of contaminants of potential concern.

A more detailed conceptual site model is presented in Section 3.0 and Section A.2.0 of this Corrective Action Investigation Plan. The conceptual model serves as the basis for the sampling strategy.

The technical approach for investigating this Corrective Action Unit consists of the following activities:

- Select sample locations using both a systematic and biased approach identifying likely worst-case areas to increase the level of certainty of finding contaminants of potential concern, if any.

- Collect environmental samples of mud and native soil using sampling methods such as direct-push techniques, if possible; residual sediment will be collected from piping.

- Collect quality control samples.

- Field screen soil samples for volatile organic compounds and alpha/beta-emitting radionuclides.

- Conduct laboratory analyses of selected environmental samples (e.g., mud, residual sediment, and soil) and quality control samples for contaminants of potential concern identified in Section A.3.0, using laboratory methods identified in Appendix C.

- Investigate piping associated with CAS 03-47-02, Mud Plant Pond, and CAS 03-09-06, Mud Disposal Crater, using a combination of visual, video, and/or electromagnetic surveys. Collect sediment samples in the piping (if possible), and submit for laboratory analysis. 
Additional sampling and analytical details are presented in Section 4.0, and details of the waste management strategy are included in Section 5.0 of this Corrective Action Investigation Plan.

Under the Federal Facility Agreement and Consent Order (1996), the Corrective Action Investigation Plan will be submitted to the Nevada Division of Environmental Protection for approval. Field work will be conducted following approval of the plan. The results of the field investigation will support a defensible evaluation of corrective action alternatives in the Corrective Action Decision Document. 


\subsection{Introduction}

This Corrective Action Investigation Plan (CAIP) has been developed in accordance with the Federal Facility Agreement and Consent Order (FFACO) that was agreed to by the U.S. Department of Energy, Nevada Operations Office (DOE/NV), the State of Nevada Division of Environmental Protection (NDEP), and the U.S. Department of Defense (FFACO, 1996). The CAIP is a document that provides or references all of the specific information for investigation activities associated with Corrective Action Units (CAUs) or Corrective Action Sites (CASs). According to the FFACO, CASs are sites potentially requiring corrective action(s) and may include solid waste management units or individual disposal or release sites. A CAU consists of one or more CASs grouped together based on geography, technical similarity, or agency responsibility for the purpose of determining corrective actions.

This CAIP contains the environmental sample collection objectives and criteria for conducting site investigation activities at CAU 34, Area 3 Contaminated Waste Sites. This CAU is located within the Area 3 Compound of the Nevada Test Site (NTS) and in the vicinity of the Mud Plant Facility. The NTS is approximately 65 miles (mi) northwest of Las Vegas, Nevada (Figure 1-1). The Mud Plant Facility is located approximately 24 mi north of Mercury, Nevada, on the Mercury Highway, and several hundred feet east along Road 3-03 which bisects the Area 3 Compound yard (Figure 1-2).

CAU 34 is comprised of the following CASs:

- CAS 03-09-07, Mud Pit

- CAS 03-44-01, Chromium Contamination Spill

- CAS 03-47-02, Area 3 Mud Plant Pond

- CAS 03-09-06, Mud Disposal Crater

CAS 03-09-07, Mud Pit, consists of a 245- by 315-foot (ft) fenced, bermed mud pit. It is located $250 \mathrm{ft}$ north of the U3gd crater and south of the Area 3 camp. In the northeast corner of the mud pit is an internal bermed pit approximately 100 by $40 \mathrm{ft}$ in size. Historical documentation indicates the mud pit possibly received both pre- and postshot drilling waste and drill yard washings.

CAS 03-44-01, Chromium Contamination Spill, consists of a 2- by 3-ft area located on the east side of the Mud Plant Building. The area is stained dark brown and consists of small, 0.5-inch (in.), chips 


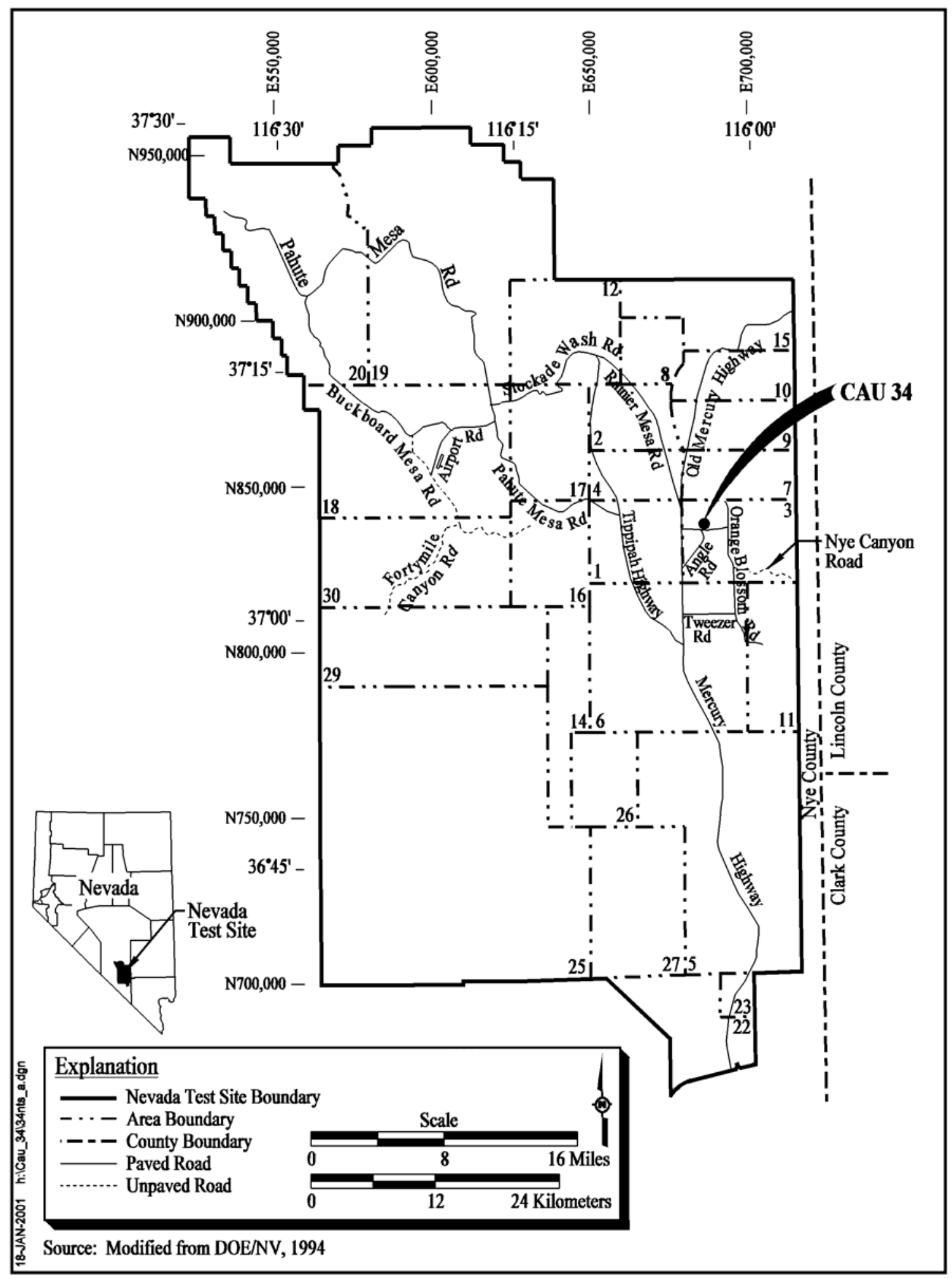

Figure 1-1

Nevada Test Site, Nye County, Nevada 


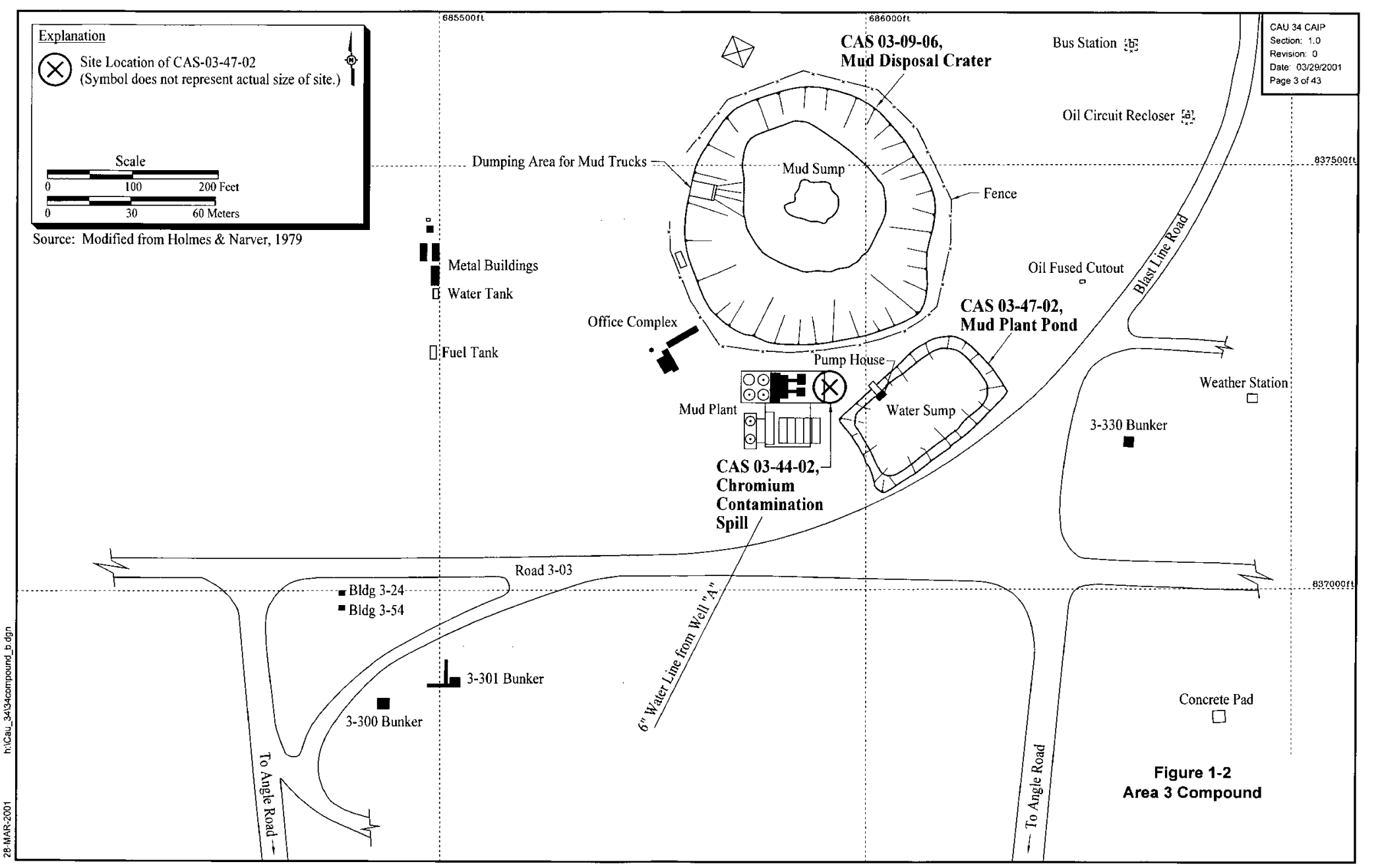


which may be the chromium-containing materials. The source of the chromium spill was Raykrome 400, a powder added in the preparation of the drilling mud used in the Mud Plant Building.

CAS 03-47-02, Mud Plant Pond, consists of a freshwater pond approximately $205 \mathrm{ft}$ in diameter and is located approximately $47 \mathrm{ft}$ east of the Mud Plant Building. This CAS was a freshwater reservoir used for the formulation of mud at the Mud Plant Building (van Drielen, 1994). It is unknown whether this CAS also received effluent containing contaminants of potential concerns (COPCs) associated with the nearby Mud Plant Building. Historical evidence reveals that the pond began to dry up in the 1992 to 1993 time frame (Witt, 2000).

CAS 03-09-06, Mud Disposal Crater, consists of the approximately 314-ft diameter, U-3ag subsidence crater (RSN, 1991). U-3ag was the site of the February 19, 1962, underground Chinchilla nuclear test (DOE/NV, 2000b). Historical data indicate the crater was then used as a mixing and storage containment for drilling mud used throughout the NTS. After the completion of the Mud Plant (prior to 1974), the crater became a disposal area and received waste from Baker tanks, vacuum trucks, and the mud plant (REECo, 1994a; DOE, 1988).

\subsection{Purpose}

Historical documentation indicates that the four CASs at CAU 34 are a result of drilling activities associated with the mud plant operations in Area 3. Historical evidence reveals that CAS 03-09-07 and CAS 03-09-06 received drilling waste and drill yard washings. CAS 03-47-02 may have also received effluent from the drilling operation; however, its main function was the freshwater reservoir for mud formulation. CAS 03-44-01 consists of chromium containing mud additives that were improperly stored outside of the Mud Plant Building and may have leaked (leached) into the surrounding soils. It is unknown whether other mud additives were also stored at this location. This CAIP presents a plan to investigate the nature and extent of COPCs at CAU 34. The purpose of the investigation described in this CAIP is as follows:

- Identify the presence and nature of COPCs.

- If COPCs are present, determine their vertical and lateral extent in surface and subsurface soils. 
- Provide sufficient information and data to determine and evaluate appropriate corrective actions for each CAS.

This CAIP was developed using the U.S. Environmental Protection Agency's (EPA) Data Quality Objectives (DQOs) process (EPA, 2000a) to clearly define the goals and set the DQOs for collecting environmental data and to design a data collection program that will satisfy these goals. A DQO scoping meeting was held prior to preparation of this plan. A brief summary of the DQO process is presented in Section 3.4, while a more detailed summary of the process and the results of the DQO meeting are included in Appendix A of this CAIP.

\subsection{Scope}

The scope of this CAIP is to resolve the problem statement identified during the DQO process, which states that potentially hazardous and/or radiological constituents may have been discharged into the four CASs that comprise CAU 34. Existing data are insufficient to evaluate and select preferred corrective actions. Therefore, the scope of the corrective action investigation for CAU 34 includes the following tasks:

- Perform a preliminary radiological survey using alpha/beta radiation detection instrumentation to determine the presence or absence of surface radiological contamination at each CAS.

- Select sample locations in likely worst-case areas to increase the level of certainty of finding COPCs, if any.

- Select random sample locations through a systematic approach (gridded system).

- Collect mud samples, where possible, and samples of soil from beneath the mud pits using drilling methods such as hollow-stem, hand auger, and direct-push techniques.

- Field screen soil samples for volatile organic compounds (VOCs) and alpha/beta-emitting radionuclides.

- Conduct laboratory analyses of environmental soil samples for COPCs identified in Section A.3.0 in accordance with methods listed in Appendix C.

- Investigate piping associated with CAS 03-47-02, Mud Plant Pond, and CAS 03-09-06, Mud Disposal Crater, using a combination of visual, video, and/or electromagnetic surveys. Collect sediment samples in the piping (if possible) and submit for laboratory analyses. 


\subsection{CAIP Contents}

Section 1.0 of this CAIP provides an introduction to this project, including the purpose and scope for this corrective action investigation. Section 2.0 provides a site description and operational history. The remainder of the document details the investigation strategy and complies with the following FFACO-required elements:

- Management

- Technical aspects

- Quality assurance

- Health and safety

- Public involvement

- Field sampling

- Waste management

The managerial aspects of this project are discussed in the DOE/NV Project Management Plan (DOE/NV, 1994) and a site-specific Field Management Plan that will be developed prior to field activities. The technical aspects of this CAIP are contained in Section 3.0 and Section 4.0 of this document and in the DQO summary presented in Appendix A. General field and laboratory quality assurance (QA) and quality control (QC) issues, including collection of QC samples, are presented in the Industrial Sites Quality Assurance Project Plan (QAPP) (DOE/NV, 1996). The general health and safety aspects of this project are discussed in the IT Corporation, Las Vegas Office (ITLV), Health and Safety Plan (HASP) (IT, 2001) and will be supplemented with a site-specific HASP (SSHASP) written and approved prior to the start of field work. As required by the U.S. Department of Energy (DOE) Integrated Safety Management System (ISMS), these documents outline the requirements for protecting the health and safety of workers and the public, and procedures for the protection of the environment. No CAU-specific public involvement activities are planned at this time; however, an overview of public involvement is documented in the "Public Involvement Plan" in Appendix V of the FFACO. Field-sampling activities are discussed in Section 4.0 of this CAIP; waste management issues are discussed in Section 5.0. The project schedule and records availability information for this CAIP are discussed in Section 6.0, and Section 7.0 provides a list of project references. 


\subsection{Facility Description}

The following sections provide background information and process knowledge as it relates to the physical setting and operational history of CAU 34. This information was gathered from historical documents, photographs, engineering drawings, site maps, interviews with former site employees, and field visits.

\subsection{Physical Setting}

Corrective Action Unit 34 is located within Area 3 of the NTS (see Figure 1-1). Area 3 is located within Yucca Flat, a topographically closed valley at the east side of the NTS. Surficial sediments consist of Quaternary and Tertiary valley-fill alluvium derived from the surrounding mountains. The alluvium consists of gravel and sand with intermittent silt beds. (IT, 1993)

Groundwater beneath Yucca Flat occurs within valley-fill, welded-tuff, bedded-tuff, and lower carbonate aquifers, and within the upper clastic and lowers clastic aquitards (DRI, 1988). The depth and quality of the groundwater in the vicinity of the operation was most likely unaffected by the operations at the Area 3 Compound. There is no water well in the immediate vicinity of the compound. The closest well was Well A, Area 3, which is no longer in operation. Well A is downgradient from the compound in the aquifer underneath the Area 3 mud plant. Groundwater is estimated to be at a depth of 1,610 ft below ground surface (bgs) at the Area 3 Compound. (REECo, 1994a)

\subsection{Operational History}

The following sections provide the operational history of the CASs that comprise CAU 34.

\subsubsection{CAS 03-09-07, Mud Pit}

The Mud Pit is located south of the Area 3 camp (Figure 2-1). The site consists of an approximately 315 x $245 \mathrm{ft}$ mud pit with an approximately 100 x $40 \mathrm{ft}$ internal bermed area at the northeast corner of the larger pit. The interior bermed area was used for disposal of excess mud from washing drilling equipment, specifically Baker and Shaker tanks. The mud pit was used for disposal from 1968 to 


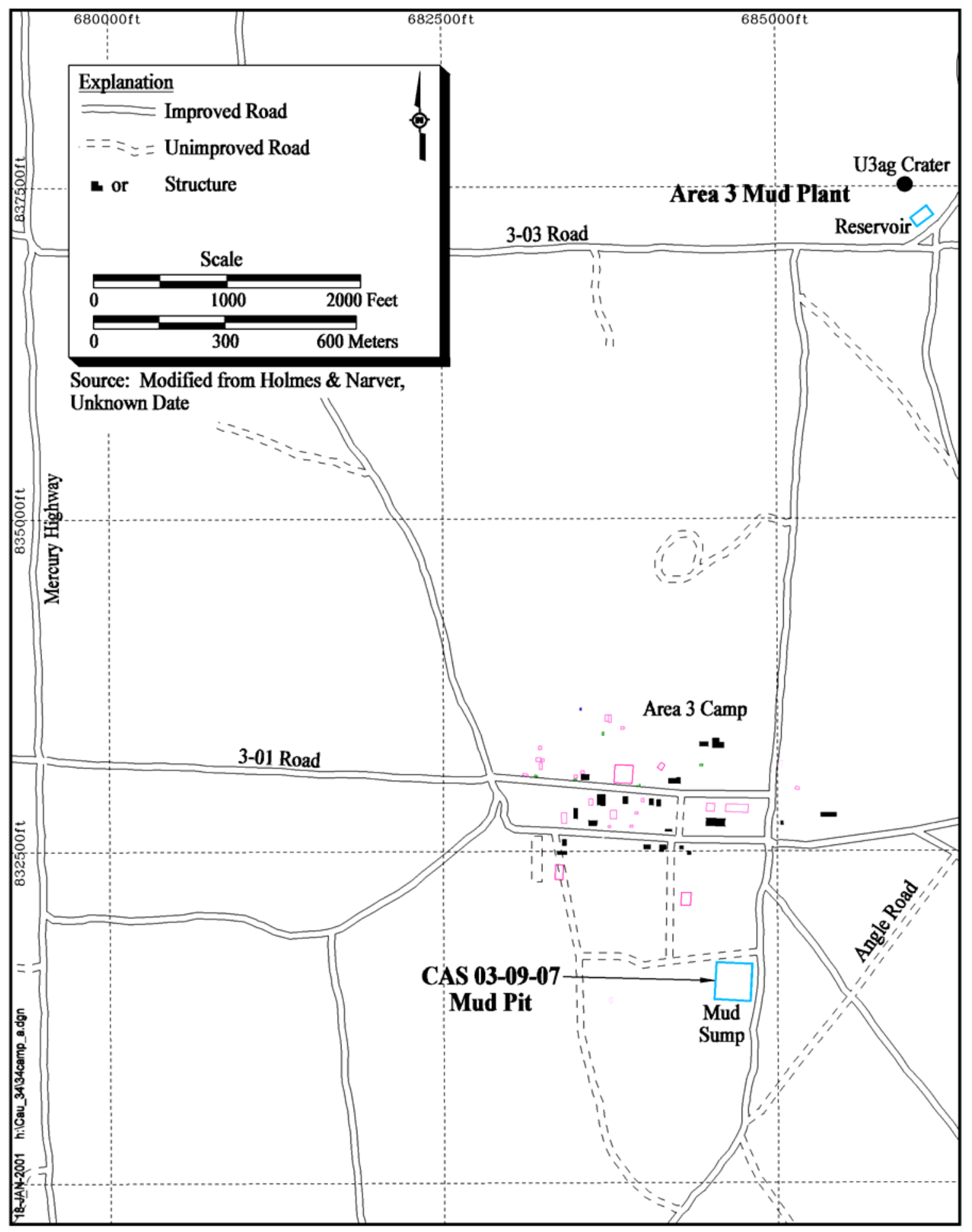

Figure 2-1

Area 3 Camp and Mud Plant 
sometime prior to 1974, at which time the U3ag crater (CAS 03-09-06) began to be used for excess mud disposal. The mud pit is currently inactive.

\subsubsection{CAS 03-44-01, Chromium Contamination Spill}

The chromium spill is located against the east side of the Mud Plant Building and is approximately 2 x $3 \mathrm{ft}$ in size. From the early 1960s to the mid-1990s, the mud plant was utilized to formulate drilling mud which provided lubrication and stabilization for the walls of drill holes, primarily in Areas 1, 2, and 3 (Carey and Co., 1993). Historical documentation indicates that chromiumcontaining additives were used in the formulation of drilling mud. An inventory of the mud additives from 1991 lists Raykrome 400, which contains Chrome Lignosulfate (4 percent Chromium) (LANL, 1991). A drilling mud specification sheet shows that Chrome Lignosulfate and Chrome Lignite were required as chemical thinner for mud (AEC, date unknown).

The chromium spill was first identified in July 1992 as a potential solid waste management unit (REECo, 1992). In 1988, DOE discovered approximately fifty, 50-pound bags of chromium-containing mud additives which were stored outside of the mud plant. Some of the chromium-containing mud additives were stated to have been released because of the deteriorated condition of at least five of the bags (DOE/NV, 1988).

Site visits revealed that the spill area is a dark brown stain and consists of small (approximately 0.05-in.) chips.

\subsubsection{CAS 03-47-02, Area 3 Mud Plant Pond}

The Area 3 Mud Plant Pond is located approximately $47 \mathrm{ft}$ east of the Mud Plant Building at the Area 3 Mud Plant. The site consists of the Mud Plant Pond (now dry), pump house with piping, and a white discharge pipe. The pond was used as a freshwater storage reservoir for the mud plant and supplied water for a number of activities including mixing mud, rinsing and cleaning the tanks, and various washdowns (van Drielen, 1994). The pond received water by both truck and via a pipe line from Area 3, Well A. In 1994, during a site visit, that pond was described as having fish, ducks, reeds, and trees. By 1999, the pond was dry and was described as having a dried white mud in the 
bottom with dry vegetation along the pond sides. The Area 3 Mud Plant is currently in operational standby.

The white discharge pipe is located in the southwest portion of the pond, approximately halfway vertically between the top of the berm that surrounds the pond and the base of the pond. Three water intake pipelines are connected to the wooden pumphouse.

Historical documentation indicates that the mud plant pond was lined with a bentonite blanket. However, the pond has been mucked and is surrounded by heavy vegetation, indicating probable deterioration of the liner by root penetrations (van Drielen, 1994). Therefore, it can be assumed that the water in the mud plant pond did infiltrate the subsurface.

\subsubsection{CAS 03-09-06, Mud Disposal Crater}

The Mud Disposal Crater is located approximately $25 \mathrm{ft}$ north of the Mud Plant Building (Figure 2-2). The crater, U-3ag, was created by an underground nuclear detonation in 1962 called the Chinchilla test. The postshot subsidence crater, U-3ag, is approximately $314 \mathrm{ft}$ in diameter and $42 \mathrm{ft}$ deep. Following the test and until the Mud Plant facility was in operation later in 1962, the crater was used to mix and store mud. After 1962, the crater was used for disposal receiving waste from Baker tanks, vacuum trucks, and the mud plant. The Mud Disposal Crater also received wastewater from the mud plant floor drains as well as from cleaning and flushing of mix tanks (van Drielen, 1994). The crater received exotic mud mixtures including asbestos and chromate muds that were experimented with at the mud plant between 1970 and 1972 (Rowe, 2000). Sometime between 1992 and 1994, the disposal of used mud and wastewater ceased because disposal in an event crater was found to be in violation of Comprehensive Environmental Response Compensation and Liability Act (CERCLA) regulations. As a result, the waste from these sources was redirected to the Baker tanks.

Miscellaneous piping and other structures and debris exist in and around the Mud Disposal Crater. Those identified include:

- A corrugated steel culvert extending from the crater into the south berm; it is $2 \mathrm{ft}$ in diameter and approximately $15 \mathrm{ft}$ of the culvert extends from the crater

- The pipe also accommodated effluent from a 6-in. pipe which joins the 24-in. pipe at the south end; historical documentation indicates that the 6-in. pipe is a capped mud line from 


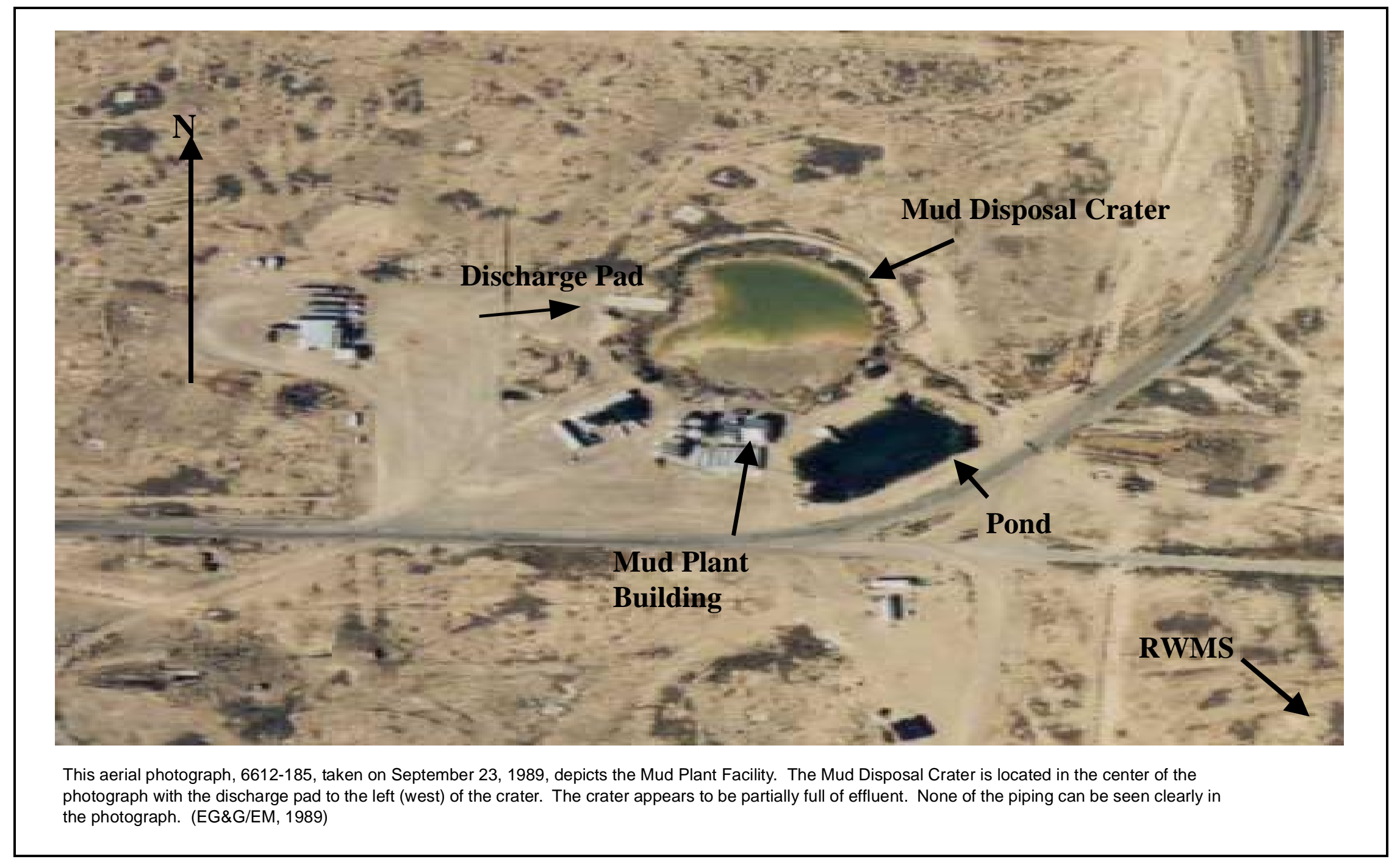
photograph with the discharge pad to the left (west) of the crater. The crater appears to be partially full of effluent. None of the piping can be seen clearly in

Figure 2-2

Aerial Photograph of Area 3 Mud Plant Compound taken September 23, 1989 
the new pump house which was used when the crater served as a storage containment for mud

- Waterline piping that runs horizontal to the ground in the bottom of the crater; approximately $40 \mathrm{ft}$ of this piping is exposed above ground

- Approximately $15 \mathrm{ft}$ of a 6-in. diameter rusted steel pipe that is exposed in the crater; this pipe is bent and broken and extends into the south berm of the crater

- Another large steel pipe approximately $3 \mathrm{ft}$ long and $2 \mathrm{ft}$ in diameter extending into the southwest berm of the crater

- In the north northwest portion of the crater, a 5 x 5 x $5 \mathrm{ft}$ cement distribution box; no associated piping is visible above the ground surface and it is unknown if the distribution box was used in place or if debris discarded into the crater from a remote site

- Two (2) concrete pads about halfway up the south side of the crater; historical documentation indicates that the pads served as mounts for the pumping equipment used when mud was mixed and stored inside the crater

- A sloped (between 15 and 20 degrees) concrete discharge pad on the west side of the crater; its function was to allow vacuum tanker trucks to back to the crater and dump waste mud and the water/mud mix resulting from the rinsing of the truck tank; this concrete pad is $10 \mathrm{in}$. thick, $20 \mathrm{ft}$ wide, and $50 \mathrm{ft}$ long; it includes pipe debris at the base, and an overflow trough at the south side of the pad

- There is a trough at the end of the concrete pad that carried the liquid away from the pad to prevent erosion; the trough is approximately $80 \mathrm{ft}$ in length; the associated piping extends in a north-south direction and is partially buried beneath the southern end of the trench

- A buried 12-in. drain pipe which discharges to the crater; this discharge pipe runs from and drains the concrete pad holding six mud storage tanks; the pipe runs about $335 \mathrm{ft}$ to the southeast corner of the crater

- Another drain pipe that discharges to the crater; it was used to drain rainwater from the crater to the overflow trough at the base of the sloped concrete pad on the west side of the crater; the crater also contained a pressure vessel used to move dry ingredients

- Drain valve piping extending from the southeast edge of the crater and traversing in an east southeast direction in the crater; it is also noted that there were repairs made to existing water lines and pumps during operation of the mud plant and new water lines were added; however, it is believed that these should have had little, if any, effect on the materials entering the crater (REECo, 1994a) 
Historical documentation states that modifications to the Mud Disposal Crater included capping the casing with Gypseal grout and the distribution of bentonite drilling as sealant (REECo, 1994a). Recent site visits have confirmed that the surface of the Mud Disposal Crater is presently dry, but no formal documentation has been identified that declares the crater 'abandoned' or 'inactive.' There are radiological posted sites noted to the north of the Mud Disposal Crater. Table 2-1 is a time line that summarizes significant events in the operational history of CAS 03-09-06.

\section{$2.3 \quad$ Waste Inventory}

Interviews with former site employees, review of procedures, and interpretations of engineering drawings and facility processes indicate that industrial effluents were discharged to the soils at the four CASs in CAU 34. Unknown volumes and concentrations of hydrocarbons, chemical compounds, and/or radionuclides may have been released to surface and subsurface soils. During the DQO process, available information including historical sampling results were evaluated and a list of potential contaminants was developed. Release information and previous sampling efforts as summarized in Section 2.4 and Section 2.5, respectively, have identified hazardous materials present in media associated with the CASs of CAU 34.

\subsection{Release Information}

Exact quantities of contaminants released at each CAS are unknown. Exposure pathways associated with this CAU, as identified during the DQO process (see Section A.2.0), include oral ingestion, inhalation, and dermal contact (absorption) of COPCs due to inadvertent exposure during sampling and/or remediation activities. The affected medium at this CAU is soil. Groundwater impacts are not expected due to a depth to groundwater of 1,610 ft bgs at this site (REECo, 1994a). Site-specific release information is discussed in the following sections.

\subsubsection{CAS 03-09-07, Mud Pit}

Excess mud from washing drilling equipment, specifically Baker and Shaker tanks was disposed of into CAS 03-09-07, Mud Pit, for several years prior to the utilization of CAS 03-09-06, Mud Disposal Crater, in 1974. Historical documentation suggests that radiological waste may have been disposed of in the mud pit. A radiological survey performed in July 1998 revealed readings that exceeded background levels. Other COPCs may have also been released into the mud pit during its utilization. 
Table 2-1

Time Line for CAS 03-09-06

(Page 1 of 2)

\begin{tabular}{|c|c|c|}
\hline Date & Event & Source \\
\hline $\begin{array}{l}\text { June } 1959 \text { - January } \\
1962\end{array}$ & $\begin{array}{l}\text { Five preshot holes were drilled; these holes were U-3ag } \\
\text { and U-3ag, \#1 through \#4 }\end{array}$ & RSN, 1991 \\
\hline February 1962 & $\begin{array}{l}\text { The Chinchilla nuclear test, Operation Nougat, occurred; } \\
\text { an accidental release of radioactivity was only detected } \\
\text { onsite }\end{array}$ & $\mathrm{DOE} / \mathrm{NV}, 2000 \mathrm{~b}$ \\
\hline February 1962 & $\begin{array}{l}\text { Two postshot holes were drilled; these holes were U-3ag } \\
\text { PS\#1 and PS\#2; radiation was detected surrounding the } \\
\text { drill holes }\end{array}$ & RSN, 1991 \\
\hline Post-1962 & $\begin{array}{l}\text { The U-3ag subsidence crater was used for mixing and } \\
\text { storing various drilling mud }\end{array}$ & REECo, 1994a \\
\hline Pre-1974 & $\begin{array}{l}\text { After the completion of the mud plant, the crater was } \\
\text { converted into a disposal crater; it received spoiled drilling } \\
\text { muds, wash water, and area runoff }\end{array}$ & REECo, 1994a \\
\hline October 1992 & $\begin{array}{l}\text { Approval for continued use of the crater for disposing } \\
\text { wash water was pending }\end{array}$ & REECo, 1992 \\
\hline July 1994 & $\begin{array}{l}\text { Waste wash water was no longer being disposed in the } \\
\text { crater; the mud plant was expected to be in use for less } \\
\text { than one percent of the normal operational time from July } \\
1994 \text { to March } 1995\end{array}$ & Bielawski, 1994 \\
\hline August 25, 1994 & $\begin{array}{l}\text { Two water samples collected from the disposal crater, one } \\
\text { collected from the north side of the crater and the other } \\
\text { from the southeast side; review of the results indicate that } \\
\text { arsenic was found at concentrations above the detection } \\
\text { limit for the north sample; barium was found in } \\
\text { concentrations above the detection limit in both samples; } \\
\text { neither barium nor arsenic were found at concentrations } \\
\text { above action levels; a gamma scan was conducted on } \\
\text { these samples and no radionuclides were detected }\end{array}$ & REECo, 1994b \\
\hline 1995 & $\begin{array}{l}\text { The disposal crater and mud plant facility shut down; this } \\
\text { occurred around the time the REECo contract ended }\end{array}$ & $\begin{array}{l}\text { Wilkes and } \\
\text { Prothro, } 2000\end{array}$ \\
\hline
\end{tabular}


Table 2-1

Time Line for CAS 03-09-06

(Page 2 of 2)

\begin{tabular}{|c|c|c|}
\hline Date & Event & Source \\
\hline March 27,1998 & $\begin{array}{l}\text { The ITLV sampling effort included the collection of a } \\
\text { sample composed of the residual drilling mud and gravel } \\
\text { from the south side of the crater; VOCs, arsenic, barium, } \\
\text { chromium, and lead were found above the detection limit } \\
\text { but not above action levels; arsenic was the only analyte } \\
\text { found at a concentration that exceeded the EPA Generic } \\
\text { Soil-screening Levels; an alpha, beta, and gamma } \\
\text { analysis was conducted on the samples and gross beta } \\
\text { and potassium-40 were found at concentrations above the } \\
\text { detection limit, but were not above the NTS background } \\
\text { levels }\end{array}$ & Forsgren, 1998 \\
\hline March 31, 1998 & $\begin{array}{l}\text { Three samples were collected from the Mud Disposal } \\
\text { Crater; the samples consisted of dried residual mud and } \\
\text { were collected from the northwest and south sides of the } \\
\text { crater; arsenic, barium, chromium, and lead were found } \\
\text { above detection levels; arsenic was found at } \\
\text { concentrations that exceeded the EPA Generic Soil- } \\
\text { Screening Levels; waste oil was detected at } \\
\text { concentrations above the State of Nevada action levels; } \\
\text { an alpha, beta, and gamma analysis was conducted on } \\
\text { the samples; gross alpha and beta, lead-210, lead-212, } \\
\text { lead-214, thallium-208, potassium-40, radium-226, and } \\
\text { americium- } 241 \text { were detected; however, none of the } \\
\text { constituents were over NTS background levels }\end{array}$ & Bordelois, 1998 \\
\hline
\end{tabular}

In the event that hazardous/radiological contaminants were present in the effluent received by the mud pit, any remaining surface or subsurface soil contamination will be characterized as part of the investigation of this.

\subsubsection{CAS 03-44-01, Chromium Contamination Spill}

A chromium-containing mud additive (brand name "Raykrome 400") was released to the ground surface next to the east side of the Mud Plant Building resulting in a stained area approximately $2 \times 3 \mathrm{ft}$ in size. It is unknown whether other contaminants were released in close proximity to CAS 03-44-01, Chromium Contamination Spill, that may also be evident in the soil. Any remaining surface or subsurface soil contamination due to the chromium spill or other releases of hazardous contaminants will be characterized as part of the investigation of CAS 03-44-01, Chromium Contamination Spill. 


\subsubsection{CAS 03-47-02, Area 3 Mud Plant Pond}

Historical documentation suggests that the Mud Plant Pond received only clean water effluent. However, it is unknown whether any unintentional releases occurred which may have resulted in the release of hazardous contaminants into the surface and subsurface soil in the bottom of the pond. Any soil contamination will be characterized as part of the investigation of CAS 03-47-02, Mud Plant Pond.

\subsubsection{CAS 03-09-06, Mud Disposal Crater}

Historical documentation indicates that effluent material including waste from Baker tanks, vacuum trucks, and the mud plant facility was released into the Mud Disposal Crater for containment storage. In the event that hazardous contaminants were present in this effluent, any remaining surface and subsurface soil contamination will be characterized as part of the investigation of this CAS.

\subsection{Investigative Background}

Past investigations at these CASs included sampling of the pit contents and an above ground radiological screening at CAS 03-09-07, Mud Pit; liquid sampling at CAS 03-47-02, Mud Plant Pond; and liquid and mud sampling and a gamma spectrometry scan at CAS 03-09-06, Mud Disposal Crater. The CAS-specific analysis of these sampling efforts are reviewed in the following sections.

\subsubsection{CAS 03-09-07, Mud Pit}

A sampling effort was conducted at CAS 03-09-07 in August 1997. Three soil samples were collected: the first was collected near the possible influent end of the mud pit and consisted of sand material; the second sample was collected in the south-central side of the mud pit and consisted of a dried clay material; and the third sample was collected from the northern side of the mud pit and consisted of a hard, brittle, dried bentonite material. All three samples were analyzed for total VOCs, total semivolatile organic compounds (SVOCs), total petroleum hydrocarbons (TPH), total Resource Conservation and Recovery Act (RCRA) metals, and radionuclides. Arsenic was found at levels which exceed the EPA soil-screening level (SSL) for ingestion in all three of these samples. Arsenic 
was the only analyte to exceed either a detection limit or an action level for these samples (Bordelois, 1998).

An above ground informal radiological screening was performed at CAS 03-09-07 in July 1998. Two readings were taken from this site, one from the center of the large mud pit and the other from the center of the small internal bermed pit. The readings from the large pit exceeded background with readings of 16.3 disinegrations per minute ( $\mathrm{dpm}$ ) alpha and 3,240 dpm beta. Background levels were also exceeded for the reading taken from the small internal bermed pit. The readings were $38.1 \mathrm{dpm}$ alpha and 77,600 dpm beta. Background levels at this site were determined to be $10.6 \mathrm{dpm}$ alpha and 2,036 dpm beta. No geophysical survey results for this CAS have been identified.

\subsubsection{CAS 03-44-01, Chromium Contamination Spill}

No analytical results, geophysical surveys or radiological surveys for this CAS have been identified.

\subsubsection{CAS 03-47-02, Area 3 Mud Plant Pond}

Sampling activities for CAS 03-47-02, Mud Plant Pond, were conducted on June 26, 1994, by Reynolds Electrical \& Engineering Co., Inc. (REECo) and March 27, 1998, by ITLV. In the 1994 REECo sampling effort, water from the pond was sampled for Toxicity Characteristic Leaching Procedure (TCLP) metals (i.e., arsenic, barium, cadmium, chromium, lead, mercury, selenium, and silver), total dissolved solids, total suspended solids, turbidity, conductivity, $\mathrm{pH}$, and gamma emitters. The analytical results were nondetectable with the exception of detection for barium at the instrument detection limit (REECo, 1994b). Barium was detected at a concentration of $0.055 \mathrm{mg} / \mathrm{L}$ (Kendall, 1994). Water samples were collected by an ITLV sampling team in 1998. The samples were analyzed for TCLP RCRA metals, total organic compounds, TPH, gross alpha/beta, and gamma. Analytical results of these samples indicated concentrations above detection limits for VOCs, SVOCs, TPH, RCRA metals, and radionuclides. Arsenic concentrations in the samples analyzed exceeded EPA generic SSL for ingestion. Waste oil was found to be at concentrations that exceed the State of Nevada action level (Bordelois, 1998). 
Water samples were collected annually from water sources in and around the NTS. The results reported (DOE/NV, 1994) from the Area 3, Mud Plant Pond, in 1993 for:

- Tritium in water ranged from $-5.9 \times 10^{-8}$ to $3.5 \times 10^{-7}$ microcuries per milliliter $(\mu \mathrm{Ci} / \mathrm{mL})$.

- Gross beta in water results ranged from $2.8 \times 10^{-9}$ to $1.3 \times 10^{-8} \mu \mathrm{Ci} / \mathrm{mL}$.

- Isotopic plutonium in water results ranged from $5.9 \times 10^{-12}$ to $1.3 \times 10^{-10} \mu \mathrm{Ci} / \mathrm{mL}$.

- Strontium-90 in water result was $4.2 \times 10^{-11} \mu \mathrm{Ci} / \mathrm{mL}$.

No historical soil sampling or geophysical sampling have been identified for this CAS.

\subsubsection{CAS 03-09-06, Mud Disposal Crater}

In August 1994, a sampling effort was conducted by REECo, and two water samples were collected from the Mud Disposal Crater. One sample was collected from the north side of the crater, and the other sample was collected from the southeast side. Both samples were analyzed for RCRA metals. Review of the results from this analysis indicates that arsenic was detected in the sample from the north side of the crater. Barium was detected in both samples. Neither detection exceeded regulatory limits or action levels (REECo, 1994b).

An ITLV sampling effort took place in August 1997 at CAS 03-09-06, Mud Disposal Crater. A sample was collected from the sloping margin on the south side of the crater. Review of the laboratory analyses from this effort reveals that the sample had the following analytes at concentrations above detection limits: total VOCs, total RCRA metals, and radionuclides. Concentrations of arsenic exceeded the EPA generic SSL for ingestion (Forsgren, 1998).

Another ITLV sampling effort took place in August 1997 at CAS 03-09-06. Samples were collected from two locations in the crater. The first sample was collected from the northwestern margin of the crater. The second location was the southern margin of the crater. The samples consisted of dried bentonite drilling mud. Review of the laboratory analyses from this effort revealed that the samples had the following analytes at concentrations above detection limits: total VOCs, total SVOCs, TPH, total RCRA metals, and radionuclides. Concentrations of arsenic exceeded the EPA SSL for ingestion, and concentrations of waste oil exceeded the State of Nevada action level for TPH in soil samples (Bordelois, 1998). 
A gamma spectrometry scan was conducted on two water samples collected from the north and southeast sides of the crater in 1994, no radionuclides were detected (REECo, 1994b). Alpha, beta, and gamma analyses were conducted on the sample collected from the south side of the crater in 1998. A review of the results indicated that gross beta and potassium- 40 were cited as being over the detection limit, but were not above NTS background levels (Forsgren, 1998). A review of the results from an alpha, beta, and gamma analysis performed on the sample collected in 1998 from the northwest and south sides of the crater indicate that gross alpha, gross beta, lead-210, lead-212, lead-214, thallium-208, potassium-40, radium-226, and americium-241 were found to be above detection limits, but did not exceed NTS background levels (Bordelois, 1998). 


\subsection{Objectives}

The DQOs are qualitative and quantitative statements that specify the quality of the data required to support potential closure alternatives for CAU 34. The DQOs were developed to clearly define the purposes for which environmental data will be used and to design a data collection program that will satisfy these purposes. The formulation of a conceptual site model is an aid to the development of DQOs for the site.

\subsection{Conceptual Site Model}

The conceptual site model defines the expected nature and extent of contamination within CAU 34 . The conceptual site model for this CAU is based on assumptions formulated from information presented in Section 2.0 and discussed during the DQO process. The conceptual site model for CAU 34 is presented in Appendix A and is summarized as follows:

- $\quad$ The COPCs, if present, are associated with the (1) disposal of used drilling mud and wastewater in the Mud Pit, the Mud Plant Pond, and the Mud Disposal Crater and (2) effluent discharge from truck dumping activities into the Mud Disposal Crater.

- Contamination, if present, will be confined laterally within the historical boundaries of the Mud Pit, the Mud Plant Pond, and the Mud Disposal Crater.

- Vertical migration of contamination, if present, will be limited based on the characteristics of the contamination, the low potential of migration through the media, and under the current conditions the absence of driving forces to facilitate migration at the Mud Pit, the Chromium Contamination Spill, Mud Plant Pond, and Mud Disposal Crater.

- Radionuclides are not anticipated at the Chromium Contamination Spill or Mud Plant Pond. Radionuclides may be present (1) in the Mud Pit and Mud Disposal Crater from disposal of contaminated used drilling mud and (2) at the Mud Disposal Crater, from backing contaminated trucks into the crater for dumping, rinsing the trucks' tanks, and subsequent effluent discharge.

- The construction, geometry, and source(s) of the pipes associated with the Mud Disposal Crater are not fully known.

- Exposure pathways are ingestion, inhalation, and dermal contact. 
- Groundwater impact is unlikely because the depth to groundwater is extensive (approximately 1,610 ft bgs at Area 3, Water Well A, which is located about 1,250 ft northwest of the site [REECo, 1994a]) and the environmental conditions at the site (i.e., arid climate, high evaporation), combined with the physical characteristics of mud, are not conducive to downward migration of COPCs.

- Floodplain studies have not been identified for this CAU.

\subsection{Contaminants of Potential Concern}

During the DQO process, COPCs for each CAS were identified through process knowledge and site history. The COPCs vary slightly for each CAS included in CAU 34. The following is a listing of the site-specific analytes to be measured to determine the nature and extent of potential contamination at each CAS:

\section{CAS 03-09-07, Mud Pit}

- VOCs

- SVOCs

- TPH (diesel-range organics)

- RCRA metals

- Radionuclides

- PCBs

\section{CAS 03-44-01, Chromium Contamination Spill}

- Total Chromium

- TCLP Chromium

- VOCs

- SVOCs

- RCRA metals

- TPH (diesel-range organics)

\section{CAS 03-47-02, Mud Plant Pond}

- VOCs

- SVOCs

- TPH (diesel-range organics)

- RCRA metals

- Radionuclides 


\section{CAS 03-09-06, Mud Disposal Crater}

- Total VOCs

- Total SVOCs

- TPH (diesel-range organics)

- RCRA metals

- Asbestos

- Radionuclides

- $\quad$ PCBs

Tables A.3-1 through A.3-4 in Appendix A list the COPCs to be analyzed for each of these CASs, including field-screening levels (FSLs) and preliminary action levels (PALs). Appendix C provides the analytical requirements which include the minimum reporting limits, analytical methods, precision, and accuracy for all analytes. Specific analyses required for disposal of investigation-derived waste (IDW) are identified in Section 5.0 of this CAIP.

\subsection{Preliminary Action Levels}

The following sections describe the FSLs and PALs for CAU 34. FSLs will be used to determine the presence of contamination and to guide the investigation. Laboratory analytical results will be compared to PALs and will guide remediation efforts. The FSLs and PALs are provided in Tables A.3-1 through A.3-4 in Appendix A. Comparison of laboratory results and the PALs will be discussed in the Corrective Action Decision Document (CADD). Laboratory results above PALs indicate the presence of COPCs at levels that may require corrective action. Laboratory results below PALs indicate that corrective action is not necessary. Based on the results of this field investigation, the evaluation of potential corrective alternatives and the justification for a preferred corrective action will be presented in the CADD.

\subsubsection{Field-Screening Levels}

The following FSLs will be used for on-site field-screening methods:

- The VOC headspace screening levels are established at 20 parts per million (ppm) or 2.5 times background, whichever is greater, using a photoionization detector.

- The radiation (alpha/beta) screening level is defined as the mean surficial-background activity level plus two times the standard deviation of the mean surficial-background activity level. 
Concentrations exceeding FSLs will indicate potential contamination at that particular sample location. This information will be documented and the investigation will continue to delineate the extent of the contamination, as necessary. Additionally, these field-screening data will be used to select discretionary samples for laboratory analyses.

\subsubsection{Chemical Preliminary Action Levels}

Off-site laboratory analytical results will be compared to the following PALs to evaluate the need for possible corrective actions:

- NDEP Corrective Action Regulations 445A.2272 (NAC, 1999a); for purposes of this CAIP, Region 9 PRGs for industrial soils are the PALs (EPA, 2000b)

- TPH concentrations above the TPH limit of 100 ppm per the Nevada Administrative Code (NAC) 445A.2272 (NAC, 1999a)

\subsubsection{Radiological Preliminary Action Levels}

The PALs for radionuclides are isotope-specific and defined as the maximum concentration for that isotope found in environmental samples taken from undisturbed background locations in the vicinity of the NTS, as presented in McArthur and Miller (1989) and Atlan-Tech (1992). The PAL for each isotope will be the maximum concentration of that isotope found in any of the samples taken from the undisturbed background locations described above.

\subsection{DQO Process Discussion}

Details of the DQO process are presented in Appendix A. During the DQO discussions for this CAU, the need for a biased sampling approach was identified which generated a number of sampling locations in potential "worst-case" areas. Due to the potential for contamination of native soil below the Mud Pit, the Mud Plant Pond, and Mud Disposal Crater, an investigation consisting of both mud samples and native soil below the mud was identified. In addition, the need for visual, video, and/or electromagnetic surveys of the piping associated with the Mud Plant Pond and Mud Disposal Crater was identified. The COPCs, analytical methods, and reporting limits prescribed through the DQO process are included in Appendix C, along with the precision and accuracy requirements stated in the 
latest revision of the individual EPA SW-846 Methods (EPA, 1996). Resulting data will be evaluated to confirm or refute the conceptual model. 


\subsection{Field Investigation}

This section of the CAIP contains the sampling approach for investigating CAU 34. All sampling activities will be conducted in compliance with the Industrial Sites QAPP (DOE/NV, 1996) and other applicable, approved procedures and instructions. Quality assurance and quality control requirements for field and laboratory environmental sampling are also contained in the Industrial Sites QAPP and within Appendix C. Data will be collected during field investigations to confirm or refute the conceptual model by determining if COPCs are present in concentrations exceeding the PALs. Field screening will assist the investigation in determining if COPCs are present. Laboratory analyses will be conducted for confirmation and verification of the field-screening results (FSRs).

Field activities will be performed in accordance with the current version of the ITLV HASP (IT, 2001) and an approved SSHASP prepared prior to the field effort. As required by the DOE/NV ISMS (DOE/NV, 1997), these documents outline the requirements for protecting the health and safety of the workers and the public, and the procedures for protecting the environment. The ISMS program requires that site personnel will take every reasonable step to reduce or eliminate the possibility of injury, illness, or accidents, and to protect the environment during all project activities. The following safety issues will be taken into consideration when evaluating the hazards and associated control procedures for field activities discussed in the SSHASP:

- Potential hazards to site personnel and the public including, but not limited to: radionuclides, chemicals (e.g., heavy metals, VOCs, SVOCs, TPH and PCBs), adverse and rapidly changing weather, remote location, and motor vehicle and heavy equipment operations.

- Proper training of all site personnel to recognize and mitigate the anticipated hazards.

- Work controls to reduce or eliminate the hazards including engineering controls, substitution of less hazardous materials, and personal protective equipment (PPE).

- Occupational exposure monitoring to prevent overexposures to hazards such as radionuclides, chemicals, and physical agents (e.g., heat, cold, and high wind).

- Radiological surveying for alpha/beta and gamma emitters to minimize and/or control personnel exposures. Use of the "as-low-as-reasonably-achievable" principle when dealing with radiological hazards. 
- Emergency and contingency planning and communications to include medical care and evacuation, decontamination and spill control measures, and appropriate notification of project management.

\subsection{Technical Approach}

Systematic (i.e., gridded) and biased subsurface soil and mud sampling will be conducted during the field investigation to determine the presence and the extent of COPCs and whether concentrations exceed PALs for the site. Additional samples may be collected for waste management purposes. Auguring and direct push will be the primary investigation technique for this CAU. Visual inspection, video surveys and/or electromagnetic surveys will be conducted to investigate the piping associated with CAS 03-47-02, Mud Plant Pond, and CAS 03-09-06, Mud Disposal Crater. Also at CAS 03-09-06, Mud Disposal Crater, a preliminary geophysical survey may be performed using ground-penetrating radar (GPR) to determine the presence or absence of buried debris, the depth of the mud, and contours of the bottom to help guide the investigation. The following activities will be conducted during the site investigation:

- Collect subsurface environmental mud and soil samples from biased locations within the Mud Disposal Crater, Mud Pit, and Mud Plant Pond.

- Collect surface and subsurface environmental soil samples from biased locations within the Chromium Contamination Spill.

- Collect systematically chosen environmental mud and soil samples from gridded locations within the Mud Pit, Mud Plant Pond, and Mud Disposal Crater.

- Conduct visual, video, and/or electromagnetic surveys of the pipes associated with the Mud Plant Pond and the Mud Disposal Crater. Collect sediment/sludge samples, if possible, from within the pipes.

- Field screen soil samples for VOCs.

- If VOC screening results exceed the field-screening levels, then laboratory analysis will be conducted for SVOCs and VOCs. If FSLs are not exceeded, laboratory analysis will not be conducted for those analytes.

- Field screen soil samples for radionuclides. 
- If radionuclide screening results exceed the field-screening levels, then laboratory analysis will be conducted for radionuclides. If FSLs are not exceeded, laboratory analysis will not be conducted for those analytes.

- Collect quality control samples.

- Conduct laboratory analysis for COPCs listed in Section A.3.0, discussed in Appendix A, and included in Appendix $\mathrm{C}$ as determined by field-screening results.

\subsection{Field Screening}

Field screening provides semiquantitative measurements of soil conditions. Results will be used to guide the investigation and aid in the selection of samples to be submitted for laboratory analysis. Field screening for VOCs and alpha/beta-emitting radionuclides will be conducted at all sampling locations. Field screening for VOCs will utilize the headspace method (i.e., photoionization detector). An Electra alpha/beta scintillator will be used to field screen for alpha/beta-emitting radionuclides. The FSLs for each method are detailed in Section 3.3.1.

\subsection{Sampling Criteria}

Samples will be selected from each location for laboratory analysis. At the Mud Pit, the Mud Plant Pond, and the Mud Disposal Crater, the sample collected from the first (mud) interval (or from the surface, if there is not enough mud), and the sample with the highest FSR will be sent for laboratory analysis. In addition, the soil sample collected from the first of two consecutive "clean" intervals (i.e., FSRs lower than FSLs) will be submitted for analysis. If FSLs are not exceeded at any of the intervals at a sample location, at least two samples from each location will be sent for laboratory analysis at the discretion of the Site Supervisor. Field-screening methods and FSLs are presented in Tables A.3-1 through A.3-4 of Appendix A. The COPCs identified in Section 3.2 of this CAIP will be analyzed in accordance with the requirements in Appendix C.

\subsection{CAS-Specific Investigation Strategy}

The following sections describe investigation strategies specific to the CASs included in CAU 34 . 


\subsubsection{CAS 03-09-07, Mud Pit}

A minimum of 14 locations will be sampled inside the Mud Pit. One location will be sampled at the "low spot" in the Mud Pit, based on visual inspection. If no low spot is observed, this sample will be collected along the northwest wall of the berm surrounding the pit. If it is determined through visual inspection that more than one low spot exists, additional samples will be collected. Four sample locations will be within the small internal bermed pit which is located in the northeast corner of the Mud Pit. These four sample locations include one in each of the following four quadrants of the small internal bermed pit shown in Figure A.2-1. The nine remaining sample locations include those systematically arranged in a grid across the Mud Pit. Additional samples may be collected at the discretion of the Site Supervisor to adequately characterize the nature and extent of contamination.

At each sample location in the mud pit, a sample of the residual mud will be collected if the volume of the residual mud at the location is sufficient. The second sample collected at each location will be at the mud/native soil interface (if there is an insufficient volume of mud to collect a discreet sample, the first sample collected at any location will be at the mud/native soil interface). Below the $\mathrm{mud} /$ native soil interface, a direct-push method will be used to collect samples from 0 to $1 \mathrm{ft}$ below the mud/native soil interface and 3 to $5 \mathrm{ft}$ below the interface. Samples will be field screened for VOCs and radioactivity. The direct push will be advanced until FSRs at two consecutive intervals are below FSLs. Alternative investigation methods, including drilling and excavation, may be used based on results and the discretion of the Site Supervisor.

\subsubsection{CAS 03-44-01, Chromium Contamination Spill}

Direct-push or hand-auguring techniques will be used to sample CAS 03-44-01, Chromium Contamination Spill. The first sample location will be in the center of the $2 \times 3 \mathrm{ft}$ stained area. Three additional sample locations will be at each point in a triangular-pattern around the first boring on approximate 2-ft centers, or at the discretion of the Site Supervisor based on visual observation. Samples will be collected at the surface and at 1-ft intervals at these locations. These borings will be advanced to a minimum depth of $2 \mathrm{ft}$ bgs and continue until staining is no longer apparent at two consecutive intervals. Additional samples may be collected, at the discretion of the Site Supervisor, to adequately characterize the nature and extent of contamination. 


\subsubsection{CAS 03-47-02, Area 3 Mud Plant Pond}

A minimum of 11 locations will be sampled to investigate the vertical and lateral extent of contamination in the Mud Plant Pond. Additional locations may be sampled based on FSRs or at the discretion of the Site Supervisor.

The first sample location will be at the low spot of the pond, based on visual observations. If no low spot is observed, this location will be along the northwest wall of the pond. If more than one low spot is observed, these locations will be sampled as well. The second sample location will be beneath the discharge pipe located along the southwest wall of the pond. The nine remaining sample locations include those systematically arranged in a grid across the pond. Additional samples will be collected at the discretion of the Site Supervisor to adequately characterize the nature and extent of contamination.

At each sample location in the mud pit, a sample of the residual mud will be collected if the volume of the residual mud at the location is sufficient. The second sample collected at each location will be at the mud/native soil interface (if there is an insufficient volume of mud to collect a discreet sample, the first sample collected at any location will be at the mud/native soil interface). Below the $\mathrm{mud} /$ native soil interface, a direct-push method will be used to collect samples from 0 to $1 \mathrm{ft}$ below the mud/native soil interface and 3 to $5 \mathrm{ft}$ below the interface. Subsequent depth intervals will be at 5-ft intervals. Samples will be field screened for VOCs and radioactivity. The direct push will be advanced until FSRs at two consecutive intervals are below FSLs.

\subsubsection{CAS 03-09-06, Mud Disposal Crater}

In order to investigate the Mud Disposal Crater, prior to sampling, GPR will be used to determine the depth of the mud and the contours of the bottom of the crater previous to sampling. Once this information has been determined, a minimum of 12 locations will be sampled to investigate the vertical and lateral extent of contamination in the Mud Disposal Crater, as shown by Figure A.2-4. Additional locations may be sampled at the discretion of the Site Supervisor, based on FSRs.

The first sample location will be at the low spot of the crater, based on visual observations. If no low spot is observed, this location will be along the southeast wall of the crater. If more than one low spot is observed, these locations will be sampled as well. The second sample location will be beneath the 
discharge culvert located along the south wall of the crater. The third sample location will be at the bottom of the sloping end of the drainage trough that exists at the eastern end of the sloping concrete discharge pad. The nine remaining sample locations include those systematically arranged in a grid system across the crater. Additional samples will be collected, at the discretion of the Site Supervisor, to adequately characterize the nature and extent of contamination.

At each sample location in the Mud Disposal Crater, a sample of the residual mud will be collected if the volume of the residual mud at the location is sufficient. The second sample collected at each location will be at the mud/native soil interface (if there is an insufficient volume of mud to collect a discreet sample, the first sample collected at any location will be at the mud/native soil interface). Below the mud/native soil interface, a direct-push method will be used to collect samples from 0 to $1 \mathrm{ft}$ below the mud/native soil interface and 3 to $5 \mathrm{ft}$ below the interface. Subsequent depth intervals will be at 5-ft intervals. Samples will be field screened for VOCs and radioactivity. The direct push will be advanced until FSRs at two consecutive intervals below the mud are below FSLs.

\subsubsection{Piping Investigation}

The drainpipes associated with CAS 03-47-02, Mud Plant Pond, and CAS 03-09-06, Mud Disposal Crater, will be investigated using a combination of visual inspection, video surveys, EM-31 (or equivalent) surveys, and sediment sampling (if present). The known locations of the drainpipes are shown in Figure A.2-3 and Figure A.2-4. Investigation of other drainpipes, the locations of which have yet to be identified, will follow this investigation strategy as well.

\section{- 24-Inch Corrugated Metal Pipe at CAS 03-09-06, Mud Disposal Crater}

- The geometry, extent, and contents of the 24-in. corrugated metal pipe will be inspected using visual inspection and/or a video survey.

- The open end of the pipe protruding from the wall of the crater will be visually inspected for the presence of sediment.

- If possible, a video survey will be conducted to locate the upstream end (source) of the pipe and to determine the presence or absence of sediment.

- If visual inspection and/or the video survey locate sufficient quantities of sediment, samples will be collected. If results are inconclusive and, if possible, the pipe will be breached at a nominal midpoint, an attempt will be made to collect a sediment sample at 
that location. Any samples collected will be analyzed for the chemical and radiological parameters provided in Section A.3.0.

\section{- 12-Inch Drain Pipes}

- The geometry, extent, and contents of the steel drainpipes will be inspected using visual inspection, and/or video survey, and/or an EM-31 (or equivalent) survey.

- The ends will be visually inspected for the presence of sediment.

- If possible, a video survey will be conducted to determine the presence or absence of sediment.

- If visual inspection or the video survey locate sufficient quantities of sediment, samples will be collected. If the results are inconclusive, the pipe will be breached at a nominal midpoint, and an attempt will be made to collect a sediment sample at that location. Any samples collected will be analyzed for the chemical and radiological parameters provided in Section A.3.0. 


\subsection{Waste Management}

Management of IDW will be based on regulatory requirements, field observations, process knowledge, and the results of laboratory analysis of the CAU 34 investigation samples.

Decontamination activities will be performed according to approved contractor procedures specified in the contractor field sampling instructions and as appropriate for the COPCs identified for CAU 34.

Waste other than soil, such as disposable sampling equipment, PPE, and rinsate is considered potentially contaminated waste only by virtue of contact with potentially contaminated media. Therefore, sampling and analysis of the IDW, separate from analyses of site investigation samples, may not be necessary. However, rinsate samples will be taken to support waste management activities. The data generated as a result of the site investigation, along with process knowledge, will be used whenever possible to assign the appropriate waste type (i.e., nonhazardous, hazardous, low-level radioactive waste [LLW], or mixed) to the IDW. If generated, IDW will be managed and disposed of in accordance with DOE Orders, U.S. Department of Transportation (DOT) regulations, RCRA regulations, State of Nevada requirements, and agreements and permits between DOE and NDEP.

No process knowledge has been identified to indicate that any release or disposal of any listed hazardous waste occurred. Therefore, if contaminants are identified, they will be considered to be characteristic rather than listed wastes.

\subsection{Waste Minimization}

Corrective action investigation activities have been planned to minimize IDW generation. To minimize the amount of rinsate generated, decontamination activities will only use the volume of water necessary to decontaminate equipment and personnel. Waste, such as disposable sampling equipment, decontamination rinsate, and PPE will be segregated to the greatest extent possible to minimize the generation of hazardous, radioactive, and/or mixed waste. 


\subsection{Potential Waste Streams}

Potentially contaminated waste generated during the investigation activities will be managed as three waste streams that include:

- Debris and associated trace amounts of soil

- PPE; disposable sampling equipment such as plastic and aluminum foil; and plastic linings from site operations such as decontamination areas, hazardous waste accumulation areas (HWAAs), soil staging areas, sample preparation areas, and from beneath sampling equipment

- Decontamination rinsate

Waste will be traceable to its source and to individual samples; this information will be recorded in the waste management logbook.

\subsection{Investigation-Derived Waste Management}

Management requirements for nonhazardous (i.e., solid/sanitary), hydrocarbon, hazardous, LLW, and mixed waste are discussed in the following sections. The IDW generated will be managed as potentially hazardous waste and potentially radioactive waste until laboratory results indicate either the presence or absence of RCRA-regulated constituents and/or radioactive constituents, respectively. Applicable waste management regulations and requirements are listed in Table 5-1.

\subsubsection{Nonhazardous Waste (Solid/Sanitary)}

Sanitary waste not directly associated with sampling activities typically consists of plastic, food, and paper products. This waste will be contained in plastic bags and will be transported to an approved solid waste management unit.

\subsubsection{Hydrocarbon Waste}

The action level for soil contaminated with hydrocarbons is $100 \mathrm{mg} / \mathrm{kg}$ in the State of Nevada (NAC, 1999d). Soils and associated IDW with TPH levels above $100 \mathrm{mg} / \mathrm{kg}$ and containing RCRA-regulated constituents below regulatory limits shall be managed as hydrocarbon waste and disposed of in accordance with all applicable regulations. 
Table 5-1

Waste Management Regulations and Requirements

\begin{tabular}{|c|c|c|}
\hline Waste Type & $\begin{array}{c}\text { Federal } \\
\text { Regulation }\end{array}$ & Additional Requirements \\
\hline Nonhazardous (solid/sanitary) & NA & $\begin{array}{l}\text { NRS } 444.440-444.620^{\mathrm{a}} \\
\text { NAC } 444.570-444.7499^{\mathrm{b}}\end{array}$ \\
\hline Hydrocarbon & NA & NAC 445A.2272 \\
\hline Hazardous & RCRA & $\begin{array}{c}\text { NRS } 459.400-459.600^{d} \\
\text { NAC } 444.850-444.8746^{\mathrm{e}} \\
\text { POC }^{f}\end{array}$ \\
\hline Low-Level Radioactive & NA & DOE Orders and NTSWAC \\
\hline Mixed & RCRA & $\begin{array}{l}\text { NTSWAC } \\
\text { POC }^{f}\end{array}$ \\
\hline
\end{tabular}

${ }^{a}$ Nevada Revised Statutes (NRS, 1998a)

${ }^{\mathrm{b}}$ Nevada Administrative Code (NAC, 1999b)

${ }^{\mathrm{C}}$ Nevada Administrative Code (NAC, 1999d)

${ }^{\mathrm{N} N e v a d a}$ Revised Statutes (NRS, 1998b)

${ }^{\mathrm{e}}$ Nevada Administrative Code (NAC, 1999c)

${ }^{\dagger}$ Performance Objective for the Certification of Nonradioactive Hazardous Waste (BN, 1995)

${ }^{9}$ Nevada Test Site Waste Acceptance Criteria, Rev. 3 (DOE/NV, 2000a)

NA $=$ Not Applicable

\subsubsection{Hazardous Waste}

Suspected hazardous waste will be managed in accordance with RCRA and State of Nevada hazardous waste management regulations and interpreted as follows. Suspected hazardous waste will be placed in 55-gallon drums that meet DOT specifications in accordance with 49 Code of Federal Regulations (CFR) 172 (CFR, 1998). Container markings and field records will allow wastes to be traceable back to the source. Additionally, waste may be directly sampled for characterization purposes. The type of container used will be appropriate for the particular waste in storage as specified in 40 CFR 265.172 (CFR 1999a). No incompatible waste is expected to be generated; however, if incompatible waste is encountered in the field, it will be managed in accordance with 40 CFR 265.177 (CFR, 1999b).

Hazardous waste will be characterized in accordance with the requirements of 40 CFR 261 (CFR, 1999c). Characterization will be based on analytical data, FSRs, process knowledge, or a combination thereof. Containerized wastes pending characterization will be identified with 
"Hazardous Waste Pending Analysis" markings until their regulatory status can be determined. Depending on the nature and amount of waste generated, waste management control areas may be established, such as a Satellite Accumulation Area (SAA) or a HWAA.

Suspected hazardous waste will be accumulated as applicable in a HWAA at or near the site of generation for up to 90 days in accordance with 40 CFR 262.34 (CFR, 1999d). Hazardous waste will be shipped to a permitted hazardous waste treatment, storage, or disposal facility before the expiration of the 90-day storage limit. The waste will be transported by a licensed hazardous waste hauler and accompanied by a Uniform Hazardous Waste Manifest in accordance with DOT shipping requirements. A copy of the manifest will be provided to the NDEP in accordance with State regulatory requirements.

At a minimum, the characterization of hazardous waste (which may contain rinsate) generated during this investigation will comply with the Nevada Test Site Performance Objective for Certification of Nonradioactive Hazardous Waste (BN, 1995).

\subsubsection{Low-Level Radioactive Waste}

Low-level radioactive waste, if generated, will be managed and characterized in accordance with DOE Orders and the requirements of the Nevada Test Site Waste Acceptance Criteria (NTSWAC) (DOE/NV, 2000a). Characterization will be based on analytical data, FSRs, process knowledge, or a combination thereof. Potentially contaminated IDW, such as PPE and disposable sampling equipment, will be placed in clear plastic bags marked with the date and an associated sample location and/or sample number. The plastic bags and any other LLW, such as containerized soil, will be placed in marked packages meeting DOT specifications and locked or fitted with tamper-indicating devices, as specified in 49 CFR 172 (CFR, 1998). The waste will be staged at a designated HWAA/Radioactive Controlled Area (RCA) or a HWAA/Radioactive Materials Area (RMA) pending disposal in accordance with NTSWAC requirements (DOE/NV, 2000a). Drums will be marked "Radioactive Material Pending Analysis" until a final waste characterization can be made.

Rinsate from decontamination activities may be analyzed to determine final disposition. Gross alpha and gross beta analysis may be performed on rinsate samples and the results will be used to determine final disposition. Additionally, the soil characterization results may be applied to the rinsate as part 
of the determination of final disposition. If rinsate is categorized as LLW on the basis of container-specific sampling or other methods, it will be solidified prior to NTSWAC certification activities.

Any waste to be disposed of in LLW landfills at the NTS will be characterized in accordance with the requirements of the NTSWAC and the contractor-specific waste certification program plan and implementing procedures.

\subsubsection{Mixed Waste}

Mixed waste is a combination of hazardous and radioactive waste. If generated, this waste will be managed in accordance with RCRA (CFR, 1999c) and NAC regulations (NAC, 1999a), as well as DOE requirements for radioactive waste. Where there is a conflict in regulations or requirements, the most stringent shall apply. For example, the 90-day accumulation time limit and weekly inspections per RCRA regulations will be applied to mixed waste even though it is not required for radioactive waste. Conversely, while RCRA does not require documented traceability, the NTSWAC for LLW does; therefore, traceability shall be documented.

In general, mixed waste will be managed in the same manner as hazardous waste, with added mandatory radioactive waste management program requirements. Suspected mixed waste will be managed in accordance with applicable regulations and requirements and marked with the words "Hazardous Waste Pending Analysis," pending characterization and confirmation of its regulatory status. However, once the waste determination is made, or the RCRA 90-day time requirement draws to an end, mixed waste shall be transported via a permitted hazardous waste hauler to the NTS transuranic waste storage pad for storage pending treatment or disposal. Mixed waste with hazardous waste constituents below land disposal restrictions may be disposed of at the Area 5 Radioactive Waste Management Site. Mixed waste not meeting land disposal restrictions will require development of a treatment plan under the requirements of the Mutual Consent Order between DOE and the State of Nevada (NRS, 1998b). 


\subsection{Analysis Required for the Disposal of IDW}

Additional analytical data may be required to characterize the IDW. These analyses will support waste classification to meet the waste acceptance criteria prior to the disposal at on-site NTS and off-site locations. Each of the CASs has been reviewed to ensure that sufficient analyses to support IDW disposal have been planned. The analyses required for IDW are summarized in Table 5-2. Samples submitted for laboratory analysis will be analyzed according to Appendix C. Rinsate generated during the investigation may be analyzed for any or all COPCs, based on site characterization analytical data.

Table 5-2 Analysis Required for the Disposal of IDW

\begin{tabular}{||c|c|c|c||}
\hline Corrective Action Site & $\begin{array}{c}\text { Isotopic } \\
\text { Uranium }\end{array}$ & $\begin{array}{c}\text { Isotopic } \\
\text { Plutonium }\end{array}$ & $\begin{array}{c}\text { Percent of } \\
\text { Samples }\end{array}$ \\
\hline \hline $\begin{array}{c}\text { CAS 03-09-07 } \\
\text { Mud Pit }\end{array}$ & required & required & $10 \%$ \\
\hline $\begin{array}{c}\text { CAS 03-44-01 } \\
\text { Chromium Contamination Spill }\end{array}$ & required & required & $10 \%$ \\
\hline $\begin{array}{c}\text { CAS 03-47-02 } \\
\text { Mud Plant Pond }\end{array}$ & required & required & $10 \%$ \\
\hline $\begin{array}{c}\text { CAS 03-09-06 } \\
\text { Mud Disposal Crater }\end{array}$ & required & required & $10 \%$ \\
\hline
\end{tabular}




\subsection{Duration and Records Availability}

\subsection{Duration}

After submittal of the Final CAIP for CAU 34 to NDEP (FFACO milestone deadline of July 31, 2001), the following is a tentative schedule of activities (in calendar days):

- Day 0: Preparation for field investigation will begin.

- Day 60: The field investigation, including field screening and sampling, will commence. Samples will be shipped to meet laboratory holding times.

- Day 150: The field investigation will be completed. Laboratory analytical data will be submitted.

- Day 215: The quality-assured laboratory analytical sample data will be available for NDEP review.

\subsection{Records Availability}

This document is available in the DOE public reading rooms located in Las Vegas and Carson City, Nevada, or by contacting the DOE/NV Project Manager. The NDEP maintains the official Administrative Record for all activities conducted under the auspices of the FFACO. 


\subsection{References}

AEC, see Atomic Energy Commission.

Atlan-Tech. 1992. Environmental Monitoring Report for the Proposed Ward Valley, California, LLRW Facility. Rosewall, GA.

BN, see Bechtel Nevada.

Bechtel Nevada. 1995. Nevada Test Site Performance Objective for Certification of Nonradioactive Hazardous Waste, G-E11/96.01, Rev. 0. Las Vegas, NV.

Bielawski, J.P., Reynolds Electrical \& Engineering Co., Inc. 1994. Memorandum to E.W. Kendall (REECo) entitled, "Area 3 Mud Plant Compliance Meeting," 12 July. Las Vegas, NV.

Bordelois, B., Science Applications International Corporation. 1998. Memo entitle, "CAU 236, CAS 03-47-01 Sampling Report," 31 March. Las Vegas, NV.

Carey and Co., see Carey and Co., Inc. and Desert Research Institute.

Carey and Co., Inc. and Desert Research Institute. 1993. Nevada Test Site Historic Building Survey. Prepared for the U.S. Department of Energy, Nevada Operations Office. Las Vegas, Nevada.

CFR, see Code of Federal Regulations.

Code of Federal Regulations. 1998. 49 CFR 172, "Hazardous Materials Table, Special Provisions, Hazardous Materials Communications, Emergency Response Information, and Training Requirements." Washington, DC: U.S. Government Printing Office.

Code of Federal Regulations. 1999a. 40 CFR 265.172, "Compatibility of Waste with Containers." Washington, DC: U.S. Government Printing Office.

Code of Federal Regulations. 1999b. 40 CFR 265.177, "Special Requirements for Incompatible Waste." Washington, DC: U.S. Government Printing Office.

Code of Federal Regulations. 1999c. 40 CFR Part 261, "Identification and Listing of Hazardous Waste." Washington, DC: U.S. Government Printing Office.

Code of Federal Regulations. 1999d. 40 CFR 262.34, “Accumulation Time." Washington, DC:

U.S. Government Printing Office.

DOE, see U.S. Department of Energy. 
DOE/NV, see U.S. Department of Energy, Nevada Operations Office.

DRI, see Desert Research Institute.

Desert Research Institute. 1988. CERCLA Preliminary Assessment of DOE's Nevada Operations Office Nuclear Weapons Testing Areas, Volume I. Prepared for U.S. Department of Energy, Nevada Operations Office. Las Vegas, NV: Water Resources Center.

EGG/EM, see EG\&G Energy Measurements.

EG\&G Energy Measurements. 1989. Aerial photograph 6612-185 (Figure 2-2). Nellis Air Force Base, NV: Remote Sensing Laboratory Photo Library.

EPA, see U.S. Environmental Protection Agency.

FFACO, see Federal Facility Agreement and Consent Order.

Federal Facility Agreement and Consent Order. 1996 (as amended). Agreed to by the State of Nevada, the U.S. Department of Energy, and the U.S. Department of Defense. Las Vegas, NV.

Forsgren, F., HSI Geotrans. 1998. Memorandum to R. Jackson (ITLV) entitled: "CAU 34, CAS 03-47-02, Sampling Report," 27 March. Las Vegas, NV.

H\&N, Inc., see Holmes and Narver, Inc.

Holmes and Narver, Inc. 1979. Engineering drawing entitled: “Area 3 Mud Plant,” April 1. Las Vegas, NV.

Holmes and Narver, Inc. 1987. As-Built Engineering drawing, A3-9 entitled: "Existing Water Distribution Area 3 Camp/Mud Plant Vicinity," 15 June. Las Vegas, NV.

Holmes and Narver, Inc. Unknown date. Engineering drawing entitled: "Area 3 Camp Vicinity." Las Vegas, NV.

IT, see IT Corporation.

IT Corporation. 1993. Recompletion Report for Groundwater Characterization Project (GCP) Water Well 3. Prepared for the U.S. Department of Energy, Nevada Operations Office. Las Vegas, NV.

IT Corporation. 2001. Health and Safety Plan, ITLV 13052--105. Las Vegas, NV.

Kendall, E.W., Reynolds Electrical \& Engineering Co., Inc. 1994. Letter to C.G. Postle (1994) entitled: "Area 3 Mud Plant," 13 October. Las Vegas, NV. 
LANL, see Los Alamos National Laboratory.

Los Alamos National Laboratory. 1991. Survey of Hazardous Materials Used in Nuclear Testing. Prepared by E.A. Bryant and J. Fabryka-Martin. Los Alamos, NM.

McArthur, R.D., and F.L. Miller. 1989. Off-Site Radiation Exposure Review Project (ORERP), Phase II Soil Program, DOE/NV/10384-23. Las Vegas, NV: Desert Research Institute.

NAC, see Nevada Administrative Code.

Nevada Administrative Code. 1999a. NAC 444, "Sanitation.” Carson City, NV.

Nevada Administrative Code. 1999b. NAC 444.570 - 444.7499, "Solid Waste Disposal." Carson City, NV.

Nevada Administrative Code. 1999c. NAC 444.850 - 444.8746, "Disposal of Hazardous Waste." Carson City, NV.

Nevada Administrative Code. 1999d. NAC 445A.2272, "Contamination of Soil: Establishment of Action Levels." Carson City, NV.

NRS, see Nevada Revised Statutes.

Nevada Revised Statutes. 1998a. NRS 444.440 - 444.620, "Collection and Disposal of Solid Waste." Carson City, NV.

Nevada Revised Statutes. 1998b. NRS 459.400 - 459.600, "Disposal of Hazardous Waste." Carson City, NV.

RSN, see Raytheon Services Nevada.

Raytheon Services Nevada. 1991. Nevada Test Site Drilling \& Mining Summary. Prepared by M. Bennett. Las Vegas, NV.

REECo, see Reynolds Electrical \& Engineering Co., Inc.

Reynolds Electrical \& Engineering Co., Inc. 1992. RCRA Part B Permit Application for Waste Management Activities at the Nevada Test Site, Section L, July. Las Vegas, NV.

Reynolds Electrical \& Engineering Co., Inc. 1994a. Area 3 Waste Mud Impoundment, Historical Information. Prepared by C.G. Postle. Las Vegas, NV.

Reynolds Electrical \& Engineering Co., Inc. 1994b. Laboratory Analytical Results, 25 August. Las Vegas, NV. 
Rowe, P., Stone and Webster Engineering. 2000. Record of telecon with J. Markowsky (SAIC) concerning Area 3, Mud Disposal Crater, 18 December. Las Vegas, NV.

U.S. Atomic Energy Commission. Date unknown. Specifications for Bentonite and Chemicals UC-3 and UC-4. Prepared by Fenix \& Scisson, Inc., and Petroleum Consultants. Las Vegas, NV.

U.S. Department of Energy. 1988. Environmental Survey Preliminary Report, Nevada Test Site, Mercury, Nevada, April. Washington, DC: Environment, Safety and Health, Office of Environmental Audit.

U.S. Department of Energy. 2000. Safety Management Policy, DOE Order NV P 450.4B. Las Vegas, NV.

U.S. Department of Energy, Nevada Operations Office. 1994. Project Management Plan, Rev. 0. Las Vegas, NV.

U.S. Department of Energy, Nevada Operations Office. 1996. Industrial Sites Quality Assurance Project Plan, DOE/NV--372. Las Vegas, NV.

U.S. Department of Energy, Nevada Operations Office. 1997. Integrated Safety Management Policy, DOE Order NV P 450.4. Las Vegas, NV.

U.S. Department of Energy, Nevada Operations Office. 2000a. Nevada Test Site Waste Acceptance Criteria, DOE/NV-325, Rev. 3. Las Vegas, NV.

U.S. Department of Energy, Nevada Operations Office. 2000b. United States Nuclear Tests, July 1945 through September 1992, Rev. 15, 8 December. Las Vegas, NV.

U.S. Environmental Protection Agency. 1996. Test Methods for Evaluating Solid Waste, Physical/Chemical Methods, SW-846, Third Edition, CD ROM, PB97-501928GEI (CD-ROM includes revisions to 1986, 1992, and 1994). Washington, DC.

U.S. Environmental Protection Agency. 2000a. Guidance for the Data Quality Objectives Process, EPA QA/G-4. Washington, DC.

U.S. Environmental Protection Agency. 2000b. Memorandum from S.J. Smucker to PRG table mailing list regarding Region 9 Preliminary Remediation Goals (PRGs), 1 October. San Francisco, CA.

van Drielen, H., Nevada Division of Environmental Protection, Department of Conservation and Natural Resources. 1994. Letter to Donald R. Elle (DOE) entitled: "Area 3, Mud Plant," 27 March. Las Vegas, NV. 
Wilkes and Prothro, U.S. Department of Energy, Nevada Operations Office. 2000. Record of Telecon with T. Renninger (SAIC) concerning the Area 3 Mud Plant and Mud Disposal Crater, 2 November. Las Vegas, NV.

Witt, J., U.S. Department of Energy, Nevada Operations Office. 2000. Record of telecon with K. Willse (IT) concerning Mud Plant Pond, 19 October. Las Vegas, NV. 


\section{Appendix A}

\section{Data Quality Objectives Worksheets}




\section{A.1.0 Introduction}

\section{A.1.1 Problem Statement}

Potentially hazardous and/or radiological constituents may have been discharged into the four CASs that comprise CAU 34, Area 3 Contaminated Waste Sites. The four CASs are:

- CAS 03-09-07, Mud Pit

- CAS 03-44-01, Chromium Contamination Spill

- CAS 03-47-02, Mud Plant Pond

- CAS 03-09-06, Mud Disposal Crater

CAS 03-09-07, Mud Pit, received effluent consisting of excess mud from washing drilling equipment, specifically from Baker and Shaker tanks entered into the mud pit from approximately 1968 until 1974. The effluent is believed to have possibly contained fuels, drilling additives, and radionuclides. A radiological survey performed in three areas of the mud pit revealed that two of the areas surveyed, the center of the mud pit, and the center of an internally bermed smaller pit were above background levels. A review of analytical results for samples taken from the mud pit in August 1997 suggests that americium-241 and cesium-137 concentrations exceed background levels at this site. Americium-241 concentrations were in the range of 14 to 17 picocuries per gram (pCi/g). The cesium-137 concentrations were approximately $50 \mathrm{pCi} / \mathrm{g}$. It is suggested that plutonium may also be present at this site because plutonium and americium-241 are typically in the ratio of approximately between 10 and 30 to 1 . However, no plutonium analysis was included in the data packages for the CAS. (Bordelois, 1998)

Corrective Action Site 03-44-01, Chromium Contamination Spill, consists of an area approximately $2 \times 3 \mathrm{ft}$ in size and is located against the east side of the mud plant building. Historical documents show that approximately fifty, 50-pound bags of chromium-containing mud additives were stored outside of the mud plant. Some of the mud additives are believed to have been released because of the deteriorated condition of at least five of the bags (DOE/NV, 1988). It is likely that the spill at CAS 03-44-01 consists of the same chromium-containing additive, Chrome Lignosulfate or Chrome Lignite, as referenced in historical documents (LANL, 1991). 
Corrective Action Site 03-47-02, Area 3 Mud Plant Pond, consists of a mud plant pond, a pump house, and a discharge pipe. The pond was used to store freshwater for the mud plant. Historical documentation suggests that only nonradioactive activities were conducted at the mud plant. The mud mixture was not expected to be hazardous; however, past sampling analysis results indicate COPCs including barium, arsenic, and waste oil. According to available documentation, the pond received water from Water Well A, which was used to both compound the mud and in cleaning activities. Historical documents also indicate that the pond was lined with a bentonite blanket; however, it is believed to have been mucked at least once, which may have damaged the liner (DRI, 1996; van Drielen, 1994). Visual inspection of the pond revealed that the liner is heavily fractured.

Used drilling mud; potentially contaminated wastewater from tankers, Baker tanks, and the mud plant facility; and solid debris were disposed into CAS 03-09-06, Mud Disposal Crater. Past investigations of this CAS have revealed that while VOCs, SVOCs, RCRA metals, and radionuclides were detected in samples of mud collected from within the crater, the concentrations of these analytes did not exceed regulatory limits or action levels with the exception of arsenic. Concentrations of arsenic exceeded the EPA Generic SSL for ingestion in one sample. Waste oil was detected in concentrations that exceeded the State of Nevada action level for TPH in the soil samples. Results from a gamma spectrometry scan in 1994 revealed that no radionuclides were detected (REECo, 1994b). A review of the results from an alpha, beta, and gamma analysis performed in 1998 revealed that gross alpha, gross beta, lead-210, lead-212, thallium-208, potassium-40, radium-226, and americium-241 were above detection limits, but did not exceed NTS background levels (Bordelois, 1998).

Existing information on the nature and extent of contamination at the Mud Pit, Chromium Contamination Spill, Mud Plant Pond, and Mud Disposal Crater is insufficient to evaluate and select preferred corrective actions. The CAU 34 investigation will be based on the DQOs developed by representatives of NDEP and DOE/NV. This investigation will determine if COPCs are present in concentrations exceeding regulatory levels in the soils around the Mud Pit, the Chromium Contamination Spill, the Mud Plant Pond, and the Mud Disposal Crater. If COPCs are detected, the lateral and vertical extent of contamination will be determined. Data adequate to prepare corrective action or close the site under State of Nevada regulations, RCRA, and DOE requirements will be collected. 


\section{A.1.2 DQO Meeting}

Table A.1-1 lists the individuals invited to participate in the FFACO-required DQO Kick-Off

Meeting. The goal of the DQO process is to establish the quantity and quality of environmental data required to support corrective action alternative decisions for CAU 34. The process ensures that the data collected will provide sufficient and reliable information to identify, evaluate, and technically defend the chosen corrective action. Unless otherwise required by the results of this DQO and stated in the CAIP, this investigation will adhere to the Industrial Sites QAPP (DOE/NV, 1996).

Table A.1-1 DQO Meeting Participants

\begin{tabular}{|c|c|c|}
\hline \multirow[b]{2}{*}{ Participant } & \multirow[b]{2}{*}{ Affiliation } & Meeting Date \\
\hline & & $\begin{array}{c}\text { Meeting } \\
12 / 20 / 2000\end{array}$ \\
\hline Steve Adams & IITLV & $\bar{x}$ \\
\hline Stacey Alderson & ITLV & $x$ \\
\hline Lydia Coleman & ITLV & \\
\hline Sabine Curtis & DOE/NV & \\
\hline Wolf Exner & ITLV & \\
\hline Tom Fitzmaurice & $\mathrm{BN}$ & $x$ \\
\hline Syl Hersh & ITLV & $\mathrm{x}$ \\
\hline Charlotte Franky & ITLV & \\
\hline Joe Hutchinson & ITLV & $x$ \\
\hline Jeff Johnson & ITLV & $x$ \\
\hline Alex MacKinlay & ITLV & $\bar{x}$ \\
\hline Michael McKinnon & NDEP & \\
\hline Brian Perkins & ITLV & $x$ \\
\hline Milinka Watson-Garett & ITLV & \\
\hline Jeanne Wightman & ITLV & $x$ \\
\hline Lowell Wille & ITLV & $\bar{x}$ \\
\hline Ted Zaferatos & NDEP & $\bar{x}$ \\
\hline
\end{tabular}

BN - Bechtel Nevada DOE/NV - U.S. Department of Energy, Nevada Operations Office ITLV - IT Corporation, Las Vegas Office NDEP - Nevada Division of Environmental Protection 


\section{A.2.0 Conceptual Model}

Unknown concentrations and volumes of hydrocarbons, chemical constituents, and radionuclides may have been released in surface and subsurface soils at the four CASs within CAU 34. These releases resulted from the disposal of used drilling mud and its additives, potentially contaminated wastewater, and solid debris in CAS 03-09-07, Mud Pit; CAS 03-44-01, Chromium Contamination Spill; CAS 03-47-02, Mud Plant Pond; and CAS 03-09-06, Mud Disposal Crater. At CASs 03-09-07, 03-47-02, and 03-09-06 waste oil, wastewater, radionuclides, and chemical constituents may have contaminated surface and subsurface soils during releases, disposal practices, or as a result of the migration of contamination. In addition, effluent from truck-washing operations was discharged into the Mud Disposal Crater, CAS 03-09-06. This effluent may have contained hazardous and/or radiological constituents that may have contaminated surface and subsurface soils in the vicinity of the Mud Disposal Crater. Piping associated with the Mud Disposal Crater may also be contaminated. Unknown concentrations and volumes of a chromium-containing additive remain at CAS 03-44-01. Section 2.0 of the CAIP provides additional information regarding the site, such as the operational history, waste inventories, release information, and investigative backgrounds.

Diagrammatic sketches of CAS 03-09-07, Mud Pit; CAS 03-44-01, Chromium Contamination Spill; CAS 03-47-02, Mud Plant Pond; and CAS 03-09-06, Mud Disposal Crater, are provided in Figures A.2-1 through A.2-4, respectively. The conceptual model for CAU 34 is provided in Table A.2-1. 


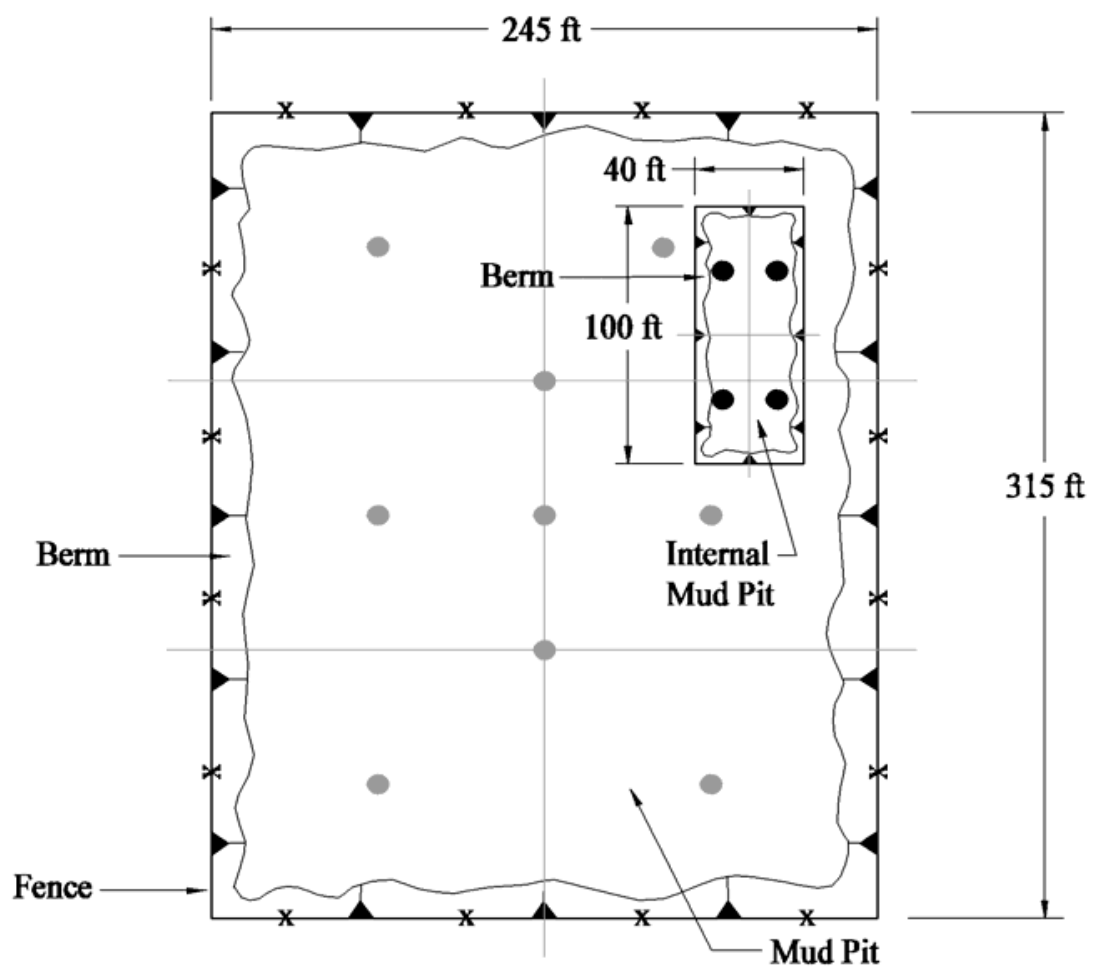

\section{Explanation}

- Biased Sample Location

- Random Sample Location

\section{$\underline{\text { Notes }}$}

1. All dimensions are approximate.

2. Sample locations are approximate. Exact locations will be determined in the field based on current site conditions.

Scale

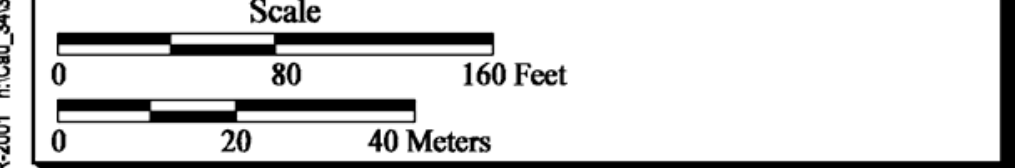

Source: IT, 2000

Figure A.2-1

CAS 03-09-07, Mud Pit Diagrammatic Sketch 


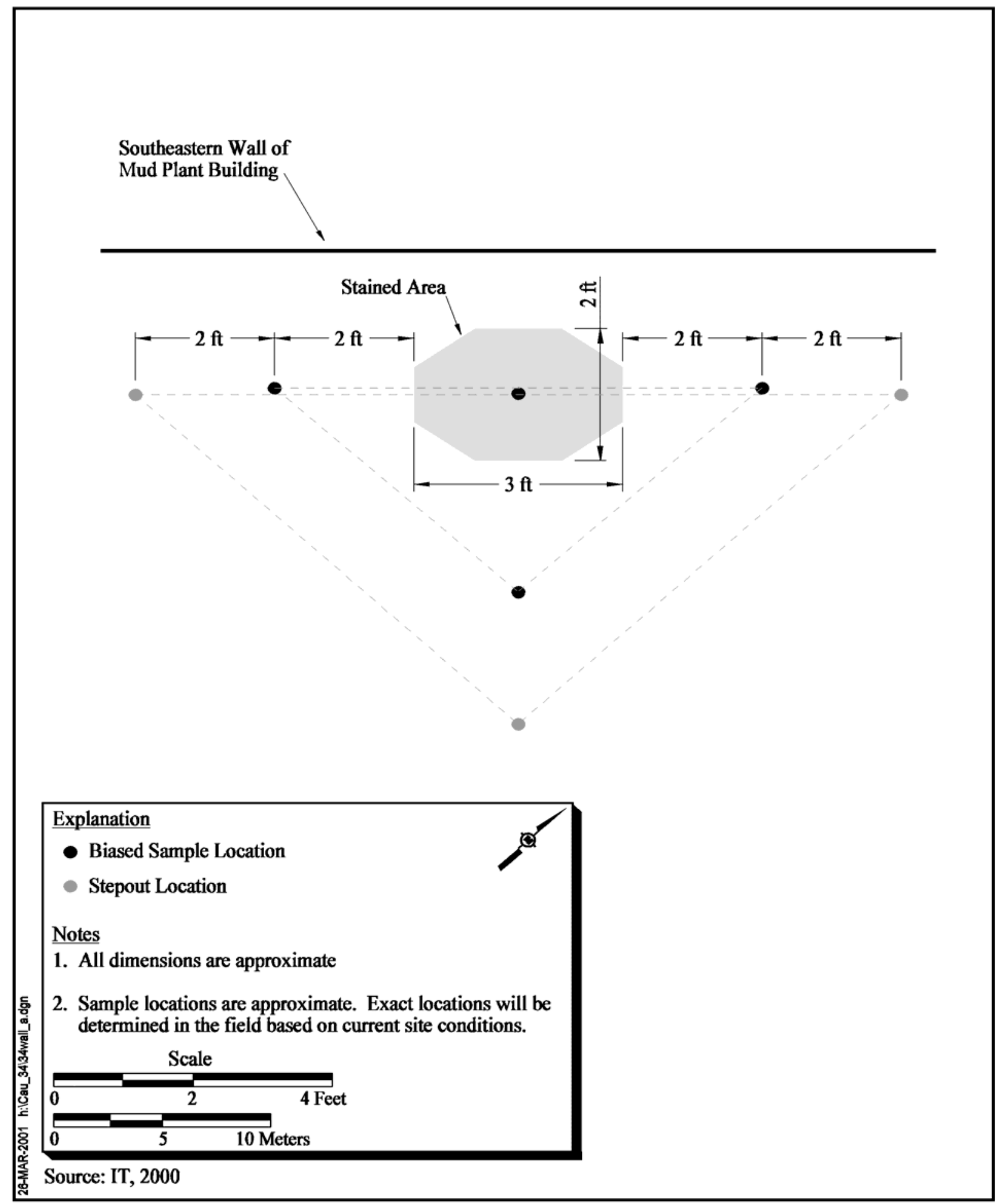

Figure A.2-2

CAS 03-44-01, Chromium Contamination Spill Diagrammatic Sketch 


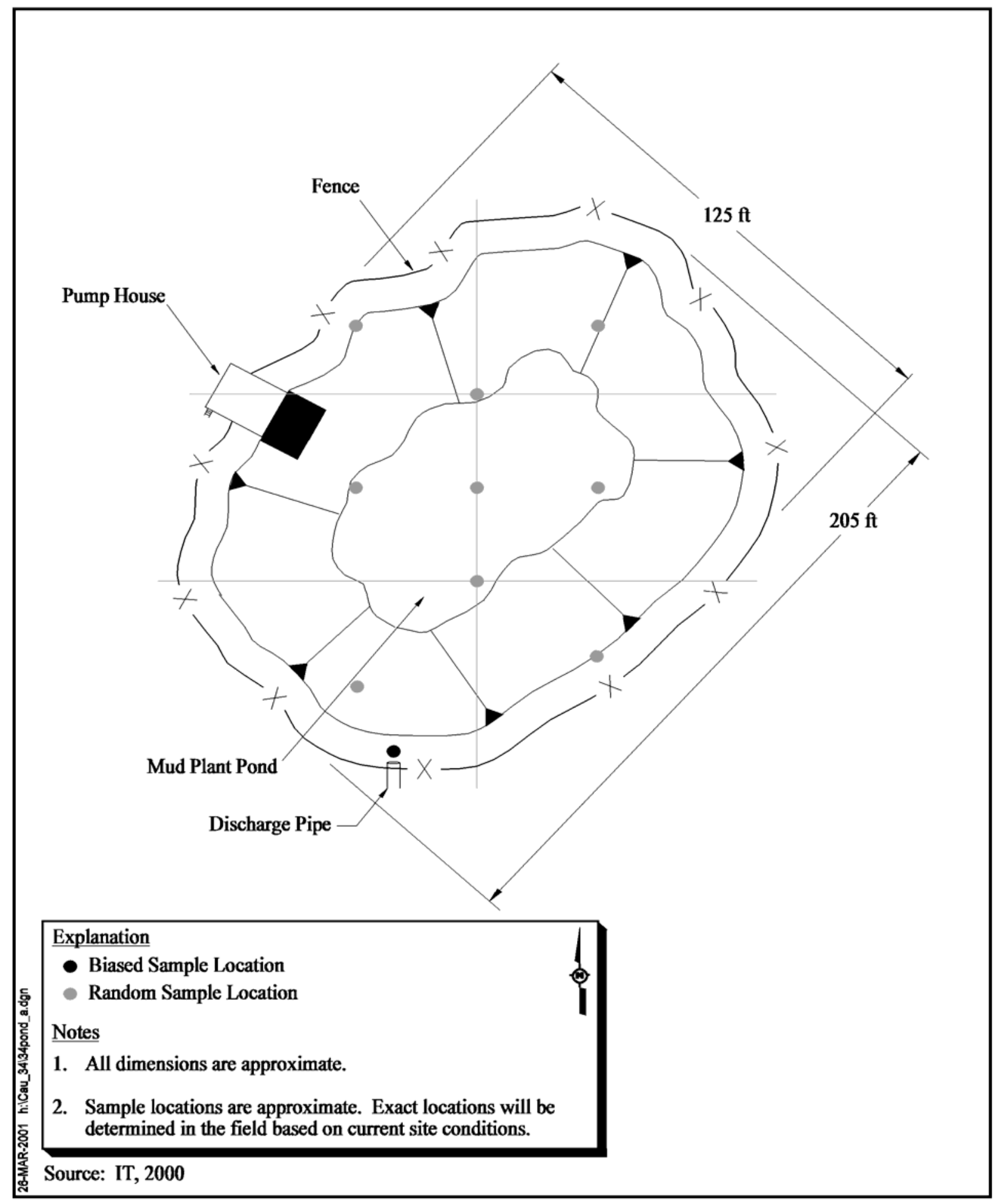

Figure A.2-3

CAS 03-47-02, Mud Plant Pond Diagrammatic Sketch 


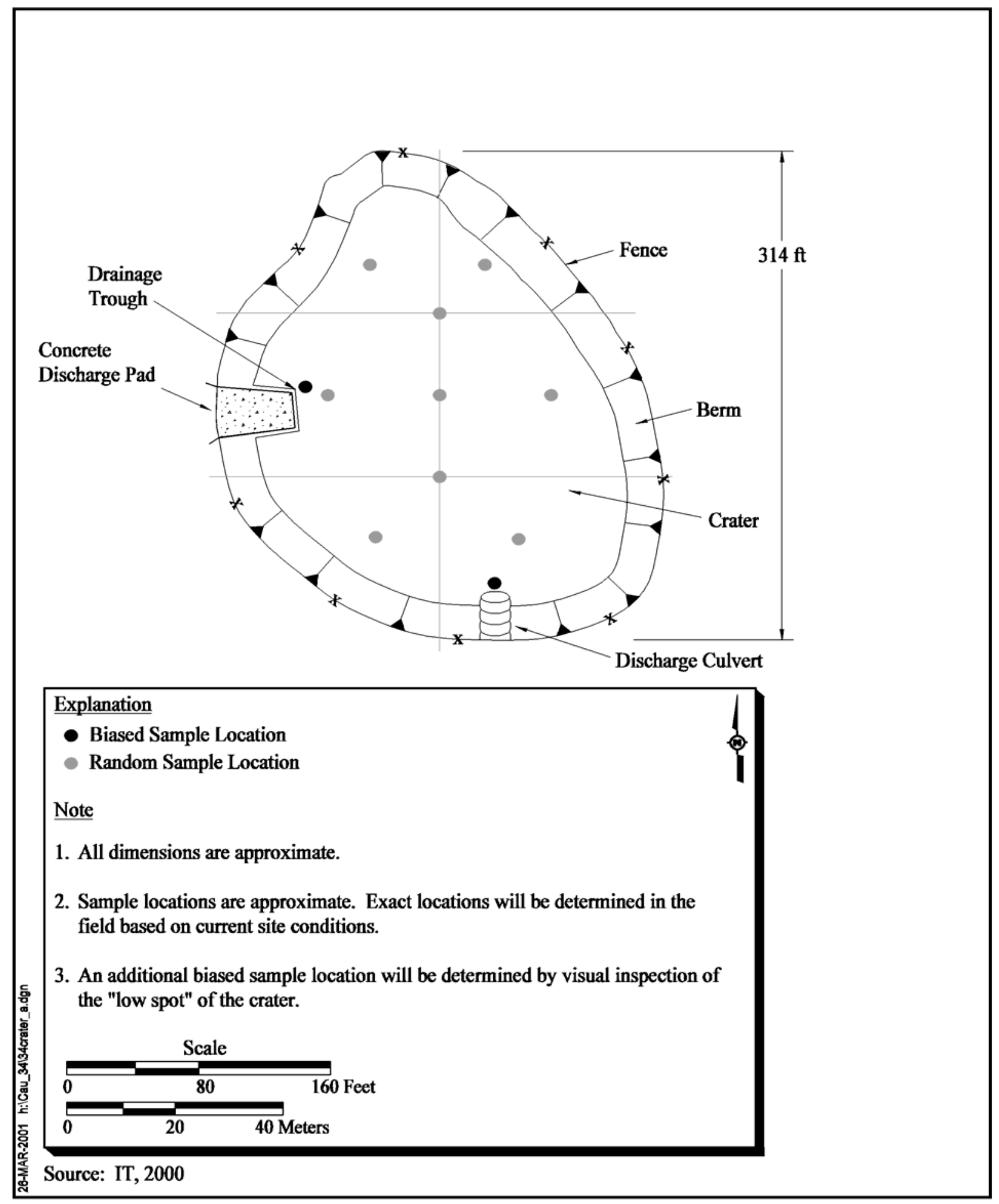

Figure A.2-4 CAS 03-09-06, Mud Disposal Crater Diagrammatic Sketch 
Table A.2-1

Conceptual Model for CAU 34, Areas 3 and 12 Contaminated Waste Sites (Page 1 of 4 )

\begin{tabular}{|c|c|c|}
\hline $\begin{array}{l}\text { Conceptual Model } \\
\text { Element }\end{array}$ & Descriptions/Assumptions & Source \\
\hline \multirow{4}{*}{ Mud Pit (CAS 03-09-07) } & $\begin{array}{l}\text { This CAS is located southwest of } 3-03 \text { Road in Area } 3 \text { of the } \\
\text { NTS. It is located approximately } 0.2 \text { miles southwest of the } \\
\text { Operator's Building. }\end{array}$ & Site investigation \\
\hline & $\begin{array}{l}\text { The creation of the mud pit occurred previous to the AJO } \\
\text { test. Preshot drilling of the crater (U3gd) associated with the } \\
\text { AJO test began in January } 1968 \text {. The Mud Pit was used for } \\
\text { disposal until the Mud Plant was built, at which time the } \\
\text { U3ag crater, Mud Disposal Crater (CAS 03-09-06), began to } \\
\text { be used for waste mud disposal. }\end{array}$ & DOE/NV, 1990 \\
\hline & $\begin{array}{l}\text { Three soils samples were collected from the Mud Pit in } \\
\text { August } 1997 \text {. VOCs, SVOCs, TPH, RCRA metals, and } \\
\text { radionuclides were detected. Concentrations of arsenic } \\
\text { exceeded the EPA SSL for ingestion. }\end{array}$ & Bordelois, 1998 \\
\hline & $\begin{array}{l}\text { A radiological survey was performed at the Mud Pit in } \\
\text { July } 1998 \text {. It revealed that the center of the Mud Pit and the } \\
\text { center of an internally bermed smaller pit were significantly } \\
\text { above background levels. }\end{array}$ & IT, 1998 \\
\hline \multirow{5}{*}{$\begin{array}{l}\text { Chromium } \\
\text { Contamination Spill } \\
\text { (CAS 03-44-01) }\end{array}$} & $\begin{array}{l}\text { This CAS is located in the Area } 3 \text { Compound, across } \\
\text { Road 3-03 and to the east of the Area } 3 \text { Mud Plant Building. }\end{array}$ & Site investigation \\
\hline & $\begin{array}{l}\text { One of the functions of the Mud Plant was to prepare drilling } \\
\text { mud by adding inorganic and organic materials. One of } \\
\text { these additives was an additive called Raykrome- } 400 \text {, which } \\
\text { contained } 4 \% \text { chromium. }\end{array}$ & LANL, 1991 \\
\hline & $\begin{array}{l}\text { Approximately } 50,50 \text {-lb bags of the chromium-containing } \\
\text { mud additive were stored outside of the Area } 3 \text { Mud Plant. } \\
\text { At least five of these bags appeared to be badly damaged } \\
\text { and leaking during a } 1988 \text { site visit. }\end{array}$ & DOE/NV, 1988 \\
\hline & $\begin{array}{l}\text { The chromium spill was identified as a potential solid waste } \\
\text { management unit in July } 1992 .\end{array}$ & REECo, 1992 \\
\hline & $\begin{array}{l}\text { Chrome Lignosulfate and Chrome Lignite are chemicals } \\
\text { specified to be used in the drilling mud formulation at the } \\
\text { Area } 3 \text { Mud Plant. They are supplied in 50-lb, multi-wall } \\
\text { bags. }\end{array}$ & DOE/NV, 1997 \\
\hline
\end{tabular}


Table A.2-1

Conceptual Model for CAU 34, Areas 3 and 12 Contaminated Waste Sites (Page 2 of 4 )

\begin{tabular}{|c|c|c|}
\hline $\begin{array}{l}\text { Conceptual Model } \\
\text { Element }\end{array}$ & Descriptions/Assumptions & Source \\
\hline \multirow{4}{*}{$\begin{array}{l}\text { Mud Plant Pond } \\
\text { (CAS 03-47-02) }\end{array}$} & $\begin{array}{l}\text { This CAS is located in the Area } 3 \text { Compound, approximately } \\
47 \text { feet east of the Mud Plant Building at the NTS. }\end{array}$ & Site investigation \\
\hline & $\begin{array}{l}\text { The Mud Plant Pond was a freshwater reservoir to be used } \\
\text { for the formulation of mud at the Area } 3 \text { Mud Plant. }\end{array}$ & Witt, 2000a \\
\hline & $\begin{array}{l}\text { There was concern that the pond water may have infiltrated } \\
\text { the Mud Disposal Crater (CAS 03-09-06), reaching the } \\
\text { crater and mobilizing contaminants. It was determined that } \\
\text { the pond would be eliminated and drained for use of excess } \\
\text { drilling mud storage when another source of water became } \\
\text { available. The Mud Plant Facility was put on operation } \\
\text { standby and the Mud Plant Pond began to dry up in } 1992 \\
\text { and } 1993 .\end{array}$ & Bielawski, 1994; Witt, 2000b \\
\hline & $\begin{array}{l}\text { The pond was sampled for TCLP RCRA metals (i.e., arsenic, } \\
\text { barium, cadmium, chromium, lead, mercury, selenium, } \\
\text { silver), total dissolved solids, total suspended solids, } \\
\text { turbidity, conductivity, pH and gamma emitters. Results } \\
\text { were nondetectable with the exception of an instrument } \\
\text { detection for barium, a known mud additive. }\end{array}$ & REECo, 1994b \\
\hline
\end{tabular}


Table A.2-1

Conceptual Model for CAU 34, Areas 3 and 12 Contaminated Waste Sites (Page 3 of 4 )

\begin{tabular}{|c|c|c|}
\hline $\begin{array}{c}\text { Conceptual Model } \\
\text { Element }\end{array}$ & Descriptions/Assumptions & Source \\
\hline \multirow{5}{*}{$\begin{array}{l}\text { Mud Disposal Crater } \\
(03-09-06)\end{array}$} & $\begin{array}{l}\text { This CAS is located in the Area } 3 \text { Compound north of the } \\
\text { Area } 3 \text { Mud Plant Building. The compound is north of } \\
\text { Road 3-03 in Area } 3 \text { of the NTS. }\end{array}$ & Site investigation \\
\hline & $\begin{array}{l}\text { The Mud Disposal Crater was originally a preshot drill hole, } \\
\text { U-3ag. U-3ag became the site of the } 1962 \text { Chincilla nuclear } \\
\text { test, which took place on February } 16,1962 \text {. } \\
\text { Documentation suggests that, following the test, the newly } \\
\text { created subsidence crater was used as a mixing and storage } \\
\text { containment for drilling mud used throughout the NTS. After } \\
\text { the completion of the Area } 3 \text { Mud Plant Facility prior to 1974, } \\
\text { the subsidence crater was converted into a disposal crater, } \\
\text { receiving waste from Baker tanks, vacuum trucks, and the } \\
\text { Mud Plant. As of 1994, Mud Plant wastewater flows were } \\
\text { redirected from the crater and into Baker tanks for } \\
\text { acceptable disposal. }\end{array}$ & $\begin{array}{l}\text { RSN, 1991; DOE/NV, } \\
\text { 2000b; REECo, 1994a; } \\
\text { DOE, 1988; Bielawski, } 1994 .\end{array}$ \\
\hline & $\begin{array}{l}\text { Two water samples were collected in } 1994 \text {. Laboratory } \\
\text { analysis found concentrations of arsenic in one sample and } \\
\text { barium in both samples, all below PALs. }\end{array}$ & REECo, 1994b \\
\hline & $\begin{array}{l}\text { One sample composed of drilling mud and minor amounts of } \\
\text { gravel was collected from the south side of the Mud Disposal } \\
\text { Crater. Laboratory analysis found concentrations of some } \\
\text { VOCs, arsenic, barium, chromium, and lead. Arsenic was } \\
\text { the only analyte recorded above regulatory limits. It } \\
\text { exceeded EPA Generic SSLs. }\end{array}$ & Forsgren, 1998 \\
\hline & $\begin{array}{l}\text { Three samples were collected from the Mud Disposal Crater } \\
\text { in } 1998 . \text { The samples consisted of dried bentonite drilling } \\
\text { mud from the northwest and south sides of the crater. Some } \\
\text { VOCs and SVOCs were detected. Waste oil was detected } \\
\text { at concentrations which exceeded the State of Nevada } \\
\text { action levels for two of the samples. Arsenic, barium, } \\
\text { chromium, and lead were detected, but arsenic was the only } \\
\text { analyte to be found at a concentration over EPA Generic } \\
\text { SSLs. }\end{array}$ & Bordelois, 1998 \\
\hline Depth to Groundwater & $\begin{array}{l}\text { Groundwater impacts are not expected. The depth to } \\
\text { groundwater generally ranges from } 1,500 \mathrm{ft} \text { bgs to the south } \\
\text { to approximately } 1,885 \mathrm{ft} \text { bgs at the north end of Area } 3 \text {. }\end{array}$ & DRI, 1996 \\
\hline $\begin{array}{c}\text { Physical and Practical } \\
\text { Constraints }\end{array}$ & $\begin{array}{l}\text { NTS-controlled activities may affect ability to characterize } \\
\text { this site. Underground utilities are expected to exist at the } \\
\text { Area } 3 \text { Compound. Adverse weather conditions and health } \\
\text { and safety concerns may affect this site. Certain health and } \\
\text { safety hazards may exist in attempting to access the pits. } \\
\text { The site is relatively remote, which may create logistical } \\
\text { constraints. }\end{array}$ & $\begin{array}{l}\text { Process knowledge } \\
\text { Site investigation }\end{array}$ \\
\hline
\end{tabular}


Table A.2-1

Conceptual Model for CAU 34, Areas 3 and 12 Contaminated Waste Sites (Page 4 of 4 )

\begin{tabular}{|c|c|c|}
\hline $\begin{array}{l}\text { Conceptual Model } \\
\text { Element }\end{array}$ & Descriptions/Assumptions & Source \\
\hline Future Use & $\begin{array}{l}\text { Future use for the Area } 3 \text { Mud Plant Facility is restricted to } \\
\text { industrial use. Its current status is listed as "operational } \\
\text { standby." }\end{array}$ & $\begin{array}{l}\text { DOE/NV, 2000a; } \\
\text { Charleton, } 2000\end{array}$ \\
\hline Potential Exposures & $\begin{array}{l}\text { Oral ingestion, inhalation, or dermal contact (absorption) of } \\
\text { COPCs due to inadvertent exposure during sampling } \\
\text { activities. }\end{array}$ & Process knowledge \\
\hline Waste Management & $\begin{array}{l}\text { Waste will be considered characteristic unless contrary } \\
\text { information is discovered during the investigation. }\end{array}$ & Process knowledge \\
\hline \multirow{3}{*}{$\begin{array}{l}\text { Lateral Extent of } \\
\text { Potential Contaminants }\end{array}$} & $\begin{array}{l}\text { Lateral extent of potential contaminants is unknown; } \\
\text { however, subsurface effects are limited by relatively low } \\
\text { contamination concentrations and low volume and/or low } \\
\text { mobility of constituents. }\end{array}$ & Process knowledge \\
\hline & $\begin{array}{l}\text { Lateral contamination is not expected to significantly extend } \\
\text { past the historical boundaries of each site. }\end{array}$ & Process knowledge \\
\hline & $\begin{array}{l}\text { The radius of lateral contamination is not expected to extend } \\
\text { beyond the borders of the Mud Disposal Crater, Mud Pit, or } \\
\text { Mud Plant Pond, as no overflow of the pits have been } \\
\text { identified. The lateral contamination of the Chromium } \\
\text { Contamination Spill remains unknown but is not expected to } \\
\text { extend more than } 10 \mathrm{ft} \text { from the center of the } 2 \times 3 \mathrm{ft} \text { stained } \\
\text { area. }\end{array}$ & Process knowledge \\
\hline \multirow[b]{2}{*}{$\begin{array}{l}\text { Vertical Extent of } \\
\text { Potential Contaminants }\end{array}$} & $\begin{array}{l}\text { The vertical extent of potential contamination is unknown. } \\
\text { Vertical extent will be controlled by surface and subsurface } \\
\text { soil geotechnical parameters, driving forces, and volume } \\
\text { and mobility of contaminants. }\end{array}$ & Process knowledge \\
\hline & $\begin{array}{l}\text { The Mud Disposal Crater Pit, and Mud Pit are unlined, } \\
\text { creating the potential for vertical migration of contaminants. } \\
\text { However, the physical characteristics of mud allows for a low } \\
\text { migration potential of contaminants. The Mud Plant Pond is } \\
\text { lined with a bentonite blanket which is thought to have been } \\
\text { damaged when the pond was mucked out. }\end{array}$ & $\begin{array}{l}\text { Process knowledge and } \\
\text { Site investigation }\end{array}$ \\
\hline
\end{tabular}




\section{A.3.0 Potential Contaminants}

Section 3.0 of the CAIP provides additional information on the COPCs for CAU 34, including PALs and QA/QC requirements. Section 5.0 of the CAIP identifies specific laboratory analyses required for the disposal of IDW. The COPCs vary slightly for each CAS included in CAU 34.

\section{A.3.1 CAS 03-09-07, Mud Pit}

The COPCs at CAS 03-09-07, Mud Pit, include VOCs, SVOCs, TPH, RCRA metals, and radionuclides that may have been discharged into the mud pit during mud disposal activities.

Process knowledge identifies the following COPCs for this CAS:

- VOCs, SVOCs, TPH (i.e., diesel-range organics), RCRA metals, PCBs, gamma emitters (i.e., Cesium-137 [Cs-137], Europium-152 [Eu-152], Europium-154 [Eu-154], Europium-155 [Eu-155], and Cobalt-60 [Co-60]), isotopic Pu, isotopic U, and Sr-90 based upon:

- Potential VOC, SVOC, TPH, RCRA metals, and PCB contamination from wastewater and used drilling mud disposal. Fuels, grease, motor oil, and hydraulic fluids are compounds that may have leaked from trucks and discharged into the pit in the effluent stream.

- Potential radioactive contamination from washing drilling trucks and downhole drilling tools that were used in both pre- and postshot holes. Note: It is assumed that decontamination procedures were followed and the equipment was sufficiently decontaminated prior to washing the equipment at the Mud Pit. However, previous sampling efforts have revealed elevated concentrations indicating that the potential exists.

\section{A.3.2 CAS 03-44-01, Chromium Contamination Spill}

Chromium is the primary COPC at CAS 03-44-01, Chromium Contamination Spill. Process knowledge indicates that Raykrome-400, total chromium as chromium lignosulfate, was released at this site. It is known that Raykrome-400 contains four percent chromium. In addition to Raykrome-400, it is unknown which mud additives might have been stored outside the Mud Plant Building. The COPCs at this site include the known constituents of mud additives including VOCs, SVOCs, RCRA metals, and TPH (i.e., diesel-range organics).

Process knowledge reveals the following COPCs for this CAS:

- Chromium 
- VOCs, SVOCs, TPH (i.e., diesel-range organics), and RCRA metals based upon the potential that other mud additives were stored outside of the Mud Plant Building.

\section{A.3.3 CAS 03-47-02, Area 3 Mud Plant Pond}

At CAS 03-47-02, the COPCs include the suite of contaminants being examined in the Mud Pit, CAS 03-09-07. They include:

- VOCs, SVOCs, TPH (e.g., diesel-range organics), RCRA metals, gamma emitters (i.e., Cs-137, Eu-154, Eu-155, Co-60), Isotopic Plutonium, Isotopic Uranium, and Strotium-90 based upon:

- It is unknown whether some of the contaminants found in the drilling mud additives were also released into the Mud Plant Pond, these COPCs must still be considered possibilities.

- The Mud Plant Pond was a freshwater reservoir used to formulate mud at the Mud Plant Facility. Since it is unknown whether some of the potential contaminants found in the drilling mud additives were also released into the Mud Plant Pond, these COPCs must still be considered possibilities.

\section{A.3.4 CAS 03-09-06, Mud Disposal Crater}

One COPC at CAS 03-09-06, Mud Disposal Crater, noted after review of analytical results is TPH as waste oil. Additives used in the mud mixing process and disposal of wastewater contribute to other COPCs including RCRA metals, PCBs, and radionuclides. Additionally, materials containing VOCs and SVOCs may have been disposed in the Mud Disposal Crater.

Process knowledge and previous sampling data identifies the following COPCs for this CAS:

- VOCs, SVOCs, RCRA metals, PCBs, TPH (e.g., diesel-range organics), asbestos, and radionuclides based upon:

- Some VOCS and SVOCs were detected in both mud samples collected from the crater. However, concentrations did not exceed PALs for these constituents. (REECo, 1994b)

- RCRA metals (i.e., barium, arsenic, chromium, and lead) were detected in soil and water samples collected from associated CAS 03-09-06. However, concentrations did not exceed PALs for these constituents. (Forsgren, 1998)

- TPH and PCB contamination from wastewater and used drilling mud disposal. Fuels, grease, motor oil, and hydraulic fluids are compounds that may have leaked from or been washed out of trucks and discharged into the crater in the effluent stream. 
- Asbestos and polymers were components of exotic mud mixtures disposed of into the crater (Rowe, 2000).

- Radionuclide contamination is possible despite nondetect results from a 1994 gamma spectrometry scan (REECo, 1994b). Historical evidence reveals possible contamination by gross alpha, gross beta, lead-210, lead-212, thallium-208, potassium-40, radium-226, americium-241, and isotopic plutonium.

Tables A.3-1 through A.3-4 identify the COPCs for each individual CAS. 
Table A.3-1

COPCs for CAS 03-09-07, Mud Pit

\begin{tabular}{|c|c|c|c|c|}
\hline Potential & Comments & $\begin{array}{l}\text { Field-Screening } \\
\text { Methods }\end{array}$ & Field-Screening Levels & $\begin{array}{l}\text { Preliminary Action } \\
\text { Levels }\end{array}$ \\
\hline VOCs & $\begin{array}{l}\text { Possible occurrence, VOCs as possible } \\
\text { constituents discharged in effluent to pond }\end{array}$ & Headspace Method & $\begin{array}{l}20 \text { ppm or } 2.5 \times \text { background } \\
\text { (use greater value) }\end{array}$ & $\begin{array}{l}\text { PRGs }{ }^{\mathrm{a}} \\
\mathrm{NAC} 445^{\mathrm{b}}\end{array}$ \\
\hline SVOCs & $\begin{array}{l}\text { Possible occurrence, SVOCs as possible } \\
\text { constituents discharged in effluent. }\end{array}$ & NA & NA & $\begin{array}{c}\text { PRGs }{ }^{a} \\
\text { NAC } 445 A^{b}\end{array}$ \\
\hline RCRA Metals & $\begin{array}{l}\text { Possible occurrence, RCRA metals as possible } \\
\text { constituents discharged in effluent. }\end{array}$ & NA & NA & $\begin{array}{c}\text { PRGs }{ }^{a} \\
\text { NAC } 445 A^{b}\end{array}$ \\
\hline $\begin{array}{l}\text { TPH (i.e., diesel- } \\
\text { range organics) }\end{array}$ & $\begin{array}{l}\text { Possible occurrence, TPH as possible } \\
\text { constituents discharged in effluent. }\end{array}$ & NA & NA & $\begin{array}{c}100 \mathrm{ppm} \\
\text { NAC } 445 A^{b}\end{array}$ \\
\hline Radionuclides & $\begin{array}{l}\text { A radiological survey performed in July } 1998 \\
\text { indicated alpha/beta readings above } \\
\text { background; background readings at this site } \\
\text { during the preliminary assessment were } \\
10.6 \mathrm{dpm} \text { alpha and } 2,036 \mathrm{dpm} \text { beta; two } \\
\text { readings were taken and revealed the following } \\
\text { results: } 16.3 \mathrm{dpm} \text { and } 38.1 \mathrm{dpm} \text { alpha, and } \\
3,240 \mathrm{dpm} \text { and } 77,600 \mathrm{dpm} \text { beta. }\end{array}$ & $\begin{array}{l}\text { Electra Alpha/Beta } \\
\text { Scintillator }\end{array}$ & $\begin{array}{l}\text { Mean background activity } \\
\text { plus } 2 \times \text { standard deviation } \\
\text { for } 20 \text { background sample } \\
\text { readings }\end{array}$ & $\begin{array}{l}\text { The PAL is the maximum } \\
\text { radionuclide } \\
\text { concentration of } \\
\text { environmental samples } \\
\text { taken from undisturbed } \\
\text { background locations. }\end{array}$ \\
\hline PCBs & $\begin{array}{l}\text { Possible occurrence, PCBs as possible } \\
\text { constituents discharged in effluent. }\end{array}$ & NA & NA & $\mathrm{PRGs}^{\mathrm{a}}$ \\
\hline
\end{tabular}

${ }^{a}$ EPA Region 9 Preliminary Remediation Goals (PRGs) (EPA, 2000)

${ }^{\mathrm{b}}$ Nevada Administrative Code (NAC, 1999)

NA $=$ Not Applicable 
Table A.3-2

COPCs for CAS 03-44-01, Chromium Contamination Spill

\begin{tabular}{|c|c|c|c|c|}
\hline Potential & Comments & $\begin{array}{l}\text { Field-Screening } \\
\text { Methods }\end{array}$ & Field-Screening Levels & $\begin{array}{l}\text { Preliminary Action } \\
\text { Levels }\end{array}$ \\
\hline Chromium & $\begin{array}{l}\text { Chrome Lignosulfate and Chrome Lignite were } \\
\text { chemicals specified to be used in drilling mud } \\
\text { formulation at the Area } 3 \text { Mud Plant; Raykrome- } 400 \text {, } \\
\text { which contains } 4 \% \text { chromium, was used at this site and } \\
\text { is believed to have leaked }\end{array}$ & NA & NA & $\begin{array}{l}\text { PRGs }{ }^{\mathrm{a}} \\
\mathrm{NAC} 445^{\mathrm{b}}\end{array}$ \\
\hline VOCs & $\begin{array}{l}\text { Possible occurrence, VOCs as possible constituents } \\
\text { discharged in effluent }\end{array}$ & Headspace Method & $\begin{array}{l}20 \text { ppm or } 2.5 \times \text { background } \\
\text { (use greater value) }\end{array}$ & $\begin{array}{l}\text { PRGs }{ }^{\mathrm{a}} \\
\mathrm{NAC} 445^{\mathrm{b}}\end{array}$ \\
\hline SVOCs & $\begin{array}{l}\text { Possible occurrence, SVOCs as possible constituents } \\
\text { discharged in effluent }\end{array}$ & NA & NA & $\begin{array}{l}\text { PRGs }{ }^{a} \\
\text { NAC } 445 A^{b}\end{array}$ \\
\hline RCRA Metals & $\begin{array}{l}\text { Possible occurrence, RCRA metals as possible } \\
\text { constituents discharged in effluent }\end{array}$ & NA & NA & $\begin{array}{l}\text { PRGs }{ }^{a} \\
\text { NAC } 445 A^{b}\end{array}$ \\
\hline $\begin{array}{l}\text { TPH (i.e., diesel- } \\
\text { range organics) }\end{array}$ & $\begin{array}{l}\text { Possible occurrence, TPH as possible constituents } \\
\text { discharged in effluent }\end{array}$ & NA & NA & $\begin{array}{c}100 \mathrm{ppm} \\
\mathrm{NAC} 445 \mathrm{~A}^{\mathrm{b}}\end{array}$ \\
\hline
\end{tabular}

EPA Region 9 Preliminary Remediation Goals (PRGs) (EPA, 2000)

${ }^{\mathrm{b}}$ Nevada Administrative Code (NAC, 1999)

NA $=$ Not Applicable 
Table A.3-3

COPCs for CAS 03-47-02, Mud Plant Pond

\begin{tabular}{|c|c|c|c|c|}
\hline Potential & Comments & $\begin{array}{l}\text { Field-Screening } \\
\text { Methods }\end{array}$ & Field-Screening Levels & $\begin{array}{l}\text { Preliminary Action } \\
\text { Levels }\end{array}$ \\
\hline VOCs & $\begin{array}{l}\text { Possible occurrence, VOCs as possible } \\
\text { constituent discharged in effluent to pond }\end{array}$ & Headspace Method & $\begin{array}{c}20 \text { ppm or } 2.5 \times \text { background } \\
\text { (use greater value) }\end{array}$ & $\begin{array}{l}\text { PRGs }{ }^{\mathrm{a}} \\
\mathrm{NAC} 445^{\mathrm{b}}\end{array}$ \\
\hline SVOCs & $\begin{array}{l}\text { Possible occurrence, SVOCs as possible } \\
\text { constituents discharged in effluent }\end{array}$ & NA & NA & $\begin{array}{c}\text { PRGs }{ }^{a} \\
\text { NAC } 445 A^{b}\end{array}$ \\
\hline RCRA Metals & $\begin{array}{l}\text { Possible occurrence, RCRA metals as } \\
\text { possible constituents discharged in effluent; } \\
\text { barium was detected in a } 1994 \text { sample effort }\end{array}$ & NA & NA & $\begin{array}{c}\text { PRGs }{ }^{a} \\
\text { NAC } 445 A^{b}\end{array}$ \\
\hline $\begin{array}{l}\text { TPH (diesel- } \\
\text { range organics) }\end{array}$ & $\begin{array}{l}\text { Possible occurrence, TPH as possible } \\
\text { constituents discharged in effluent }\end{array}$ & NA & NA & $\begin{array}{c}100 \mathrm{ppm} \\
\text { NAC } 445 \mathrm{~A}^{\mathrm{b}}\end{array}$ \\
\hline Radionuclides & $\begin{array}{l}\text { Possible occurrence, radionuclides as } \\
\text { possible constituents discharged in effluent }\end{array}$ & $\begin{array}{l}\text { Electra Alpha/Beta } \\
\text { Scintillator }\end{array}$ & $\begin{array}{l}\text { Mean background activity } \\
\text { plus } 2 \text { x standard deviation } \\
\text { for } 20 \text { background sample } \\
\text { readings }\end{array}$ & $\begin{array}{l}\text { The PAL is the maximum } \\
\text { radionuclide concentration } \\
\text { of environmental samples } \\
\text { taken from undisturbed } \\
\text { background locations. }\end{array}$ \\
\hline
\end{tabular}

${ }^{a}$ EPA Region 9 Preliminary Remediation Goals (PRGs) (EPA, 2000)

${ }^{b}$ Nevada Administrative Code (NAC, 1999)

$\mathrm{NA}=$ Not Applicable 
Table A.3-4

COPCs for CAS 03-09-06, Mud Disposal Crater

\begin{tabular}{|c|c|c|c|c|}
\hline Potential & Comments & $\begin{array}{l}\text { Field-Screening } \\
\text { Methods }\end{array}$ & Field-Screening Levels & $\begin{array}{l}\text { Preliminary Action } \\
\text { Levels }\end{array}$ \\
\hline VOCs & $\begin{array}{l}\text { Possible occurrence, VOCs as possible } \\
\text { constituent discharged in effluent to pond }\end{array}$ & Headspace Method & $\begin{array}{l}20 \text { ppm or } 2.5 \times \text { background } \\
\text { (use greater value) }\end{array}$ & $\begin{array}{l}\text { PRGs }{ }^{\mathrm{a}} \\
\mathrm{NAC} 445^{\mathrm{b}}\end{array}$ \\
\hline SVOCs & $\begin{array}{l}\text { Possible occurrence, SVOCs as possible } \\
\text { constituents discharged in effluent }\end{array}$ & NA & NA & $\begin{array}{c}\text { PRGs }{ }^{a} \\
\text { NAC } 445 A^{b}\end{array}$ \\
\hline RCRA Metals & $\begin{array}{l}\text { Possible occurrence, RCRA metals as } \\
\text { possible constituents discharged in effluent; } \\
\text { barium was detected in a } 1994 \text { preliminary } \\
\text { assessment sample effort }\end{array}$ & NA & NA & $\begin{array}{c}\text { PRGs }{ }^{a} \\
\text { NAC } 445 A^{b}\end{array}$ \\
\hline $\begin{array}{l}\text { TPH (diesel- } \\
\text { range organics) }\end{array}$ & $\begin{array}{l}\text { Possible occurrence, TPH as possible } \\
\text { constituents discharged in effluent }\end{array}$ & NA & NA & $\begin{array}{c}100 \mathrm{ppm} \\
\text { NAC } 445 \mathrm{~A}^{\mathrm{b}}\end{array}$ \\
\hline Asbestos & $\begin{array}{l}\text { Possible occurrence, asbestos used in small } \\
\text { amounts as a constituent of exotic mud } \\
\text { mixtures disposed of in crater; total } \\
\text { concentration of asbestos in the crater is } \\
\text { expected to be minimal and, thus, will not be } \\
\text { investigated further }\end{array}$ & NA & NA & NA \\
\hline Radionuclides & $\begin{array}{l}\text { Possible occurrence, radionuclides as } \\
\text { possible constituents of wastewater from } \\
\text { truck/drilling equipment washing }\end{array}$ & $\begin{array}{l}\text { Electra Alpha/Beta } \\
\text { Scintillator }\end{array}$ & $\begin{array}{l}\text { Mean background activity } \\
\text { plus } 2 \text { x standard deviations } \\
\text { for } 20 \text { background sample } \\
\text { readings }\end{array}$ & $\begin{array}{l}\text { The PAL is the maximum } \\
\text { radionuclide concentration } \\
\text { of environmental samples } \\
\text { taken from undisturbed } \\
\text { background locations. }\end{array}$ \\
\hline PCBs & $\begin{array}{l}\text { Possible occurrence, PCBs as possible } \\
\text { constituents discharged in effluent }\end{array}$ & NA & NA & $P R G s^{a}$ \\
\hline
\end{tabular}

${ }^{a}$ EPA Region 9 Preliminary Remediation Goals (PRGs) (EPA, 2000)

${ }^{\mathrm{b}}$ Nevada Administrative Code (NAC, 1999)

$\mathrm{NA}=$ Not Applicable 


\section{A.4.0 Decisions and Inputs}

\section{A.4.1 Decisions}

Decisions to be resolved by the investigation include:

- $\quad$ Determine the presence or absence of COPCs.

- If COPCs are present, determine whether COPC concentrations exceed FSLs.

- If COPCs exceed FSLs, determine whether COPC concentrations exceed PALs.

- If COPCs exceed PALs, determine the nature and extent of contamination with enough certainty to develop and evaluate a range of potential corrective action alternatives, including closure in place and clean closure.

\section{A.4.2 Inputs and Strategy}

Inputs are those elements of information used to support the decisions in addressing the identified problem. The strategy provides either the rationale to support the decision or the methodology for collecting data to arrive at the decision. A list of information inputs, existing data, data gaps, and brief strategies are discussed in Table A.4-1. 
Table A.4-1

Decisions, Inputs, and General Strategies

(Page 1 of 3 )

\begin{tabular}{|c|c|c|c|c|}
\hline Decision & Input & Existing Data & Data Gap & Strategy \\
\hline \multirow[t]{2}{*}{$\begin{array}{l}\text { Are COPCs present above } \\
\text { PALs at site? }\end{array}$} & $\begin{array}{l}\text { Potential contaminant } \\
\text { identification }\end{array}$ & $\begin{array}{l}\text { Mud Pit: Process knowledge of } \\
\text { discharge and disposal practices; } \\
\text { existing sample data from the preliminary } \\
\text { assessment conducted in } 1994 \text { and } 1998 \\
\text { Chromium Contamination Spill: } \\
\text { Historical documentation of chromium } \\
\text { release } \\
\text { Mud Plant Pond: Process knowledge of } \\
\text { use and discharge practices; existing } \\
\text { sample data from the preliminary } \\
\text { assessment conducted in } 1994 \text { and } 1998 \\
\text { Mud Disposal Crater: Process } \\
\text { knowledge of discharge and disposal } \\
\text { practices; existing sample data from the } \\
\text { preliminary assessment conducted in } \\
1994 \text { and } 1998\end{array}$ & $\begin{array}{l}\text { Exact COPCs (e.g., chromium, } \\
\text { other metals, VOCs, and SVOCs } \\
\text { identification) }\end{array}$ & $\begin{array}{l}\text { Collect soil samples and analyze for } \\
\text { COPCs }\end{array}$ \\
\hline & $\begin{array}{l}\text { Potential contaminant } \\
\text { concentration }\end{array}$ & $\begin{array}{l}\text { Existing sample data from the } \\
\text { preliminary assessment conducted in } \\
1994 \text { and } 1998 \text { (CAS 03-09-06, } \\
\text { CAS 03-09-07, and CAS 03-47-02) }\end{array}$ & $\begin{array}{l}\text { Concentrations of identified } \\
\text { COPCs }\end{array}$ & $\begin{array}{l}\text { Field screen soil samples; compare } \\
\text { FSRs to FSLs; perform laboratory } \\
\text { analysis of soil samples; compare } \\
\text { results to PALs }\end{array}$ \\
\hline
\end{tabular}


Table A.4-1

Decisions, Inputs, and General Strategies

(Page 2 of 3 )

\begin{tabular}{|c|c|c|c|c|}
\hline Decision & Input & Existing Data & Data Gap & Strategy \\
\hline $\begin{array}{l}\text { Are COPCs present above } \\
\text { PALs at site? (cont'd) }\end{array}$ & $\begin{array}{l}\text { Potential contaminant } \\
\text { distribution }\end{array}$ & $\begin{array}{l}\text { Mud Pit: Location of highest } \\
\text { concentration of contamination assumed } \\
\text { to be in the center of the small internal } \\
\text { bermed pit } \\
\text { Chromium Contamination Spill: Source } \\
\text { and original dimensions of spill area } \\
\text { known or surmised } \\
\text { Mud Plant Pond: Migration of } \\
\text { contamination assumed to be limited to } \\
\text { boundaries of the pond } \\
\text { Mud Disposal Crater: Highest } \\
\text { concentration of contamination assumed } \\
\text { to be at the discharge pipe from the Mud } \\
\text { Plant, the base of the concrete discharge } \\
\text { pad, and the low point of the crater; } \\
\text { assume most or all contamination exists } \\
\text { in the mud and has not migrated outside } \\
\text { of the crater or into native soil }\end{array}$ & $\begin{array}{l}\text { Vertical and lateral extent of } \\
\text { COPCs at all four CASs } \\
\text { Unknown whether distribution box } \\
\text { in the Mud Disposal Crater is } \\
\text { debris from a remote location or } \\
\text { part of a piping system located in } \\
\text { the Mud Disposal Crater } \\
\text { Layout and dimensions of piping } \\
\text { associated with the Mud Disposal } \\
\text { Crater and Mud Plant Pond and } \\
\text { concentration of contamination (if } \\
\text { any) within this piping }\end{array}$ & $\begin{array}{l}\text { Collect soil samples from biased } \\
\text { locations to characterize lateral and } \\
\text { vertical extent of contamination; submit } \\
\text { soil samples for analysis from surface } \\
\text { interval, interval with the highest FSR, } \\
\text { and the first two consecutive clean } \\
\text { intervals (FSRs < FSLs) } \\
\text { If contaminants are detected, add } \\
\text { step-out sampling locations, based on } \\
\text { FSRs and laboratory results, to } \\
\text { characterize lateral extent of } \\
\text { contamination } \\
\text { If contaminants are detected, collect } \\
\text { additional samples from planned } \\
\text { locations, based on FSRs, to } \\
\text { characterize vertical extent of } \\
\text { contamination } \\
\text { Conduct visual, and/or video, and/or } \\
\text { electromagnetic surveys of drainpipes } \\
\text { to establish geometry and contents; } \\
\text { collect sediment samples, if present, } \\
\text { and analyze for same COPC suite as } \\
\text { Mud Disposal Crater }\end{array}$ \\
\hline \multirow{2}{*}{$\begin{array}{l}\text { Are potential } \\
\text { contaminants migrating? }\end{array}$} & Meteorologic data & $\begin{array}{l}\text { The NTS and Yucca Mountain Site } \\
\text { Characterization Project data on annual } \\
\text { precipitation, evapotranspiration, and } \\
\text { weather (Meyers and Nordenson, 1962) }\end{array}$ & $\begin{array}{l}\text { None, sufficient information } \\
\text { available }\end{array}$ & $\begin{array}{l}\text { No site-specific meteorological data will } \\
\text { be collected; general weather } \\
\text { conditions are noted on daily field } \\
\text { notes }\end{array}$ \\
\hline & Geologic/hydrologic data & $\begin{array}{l}\text { Specific geologic/hydrologic } \\
\text { characteristics of the site }\end{array}$ & $\begin{array}{l}\text { Existence and characteristics of } \\
\text { differing permeability zones }\end{array}$ & $\begin{array}{l}\text { Assume mainly near-surface (to } 15 \mathrm{ft} \\
\text { bgs) investigation; general soil and } \\
\text { alluvial characteristics will be noted on } \\
\text { sample collection log }\end{array}$ \\
\hline
\end{tabular}


Table A.4-1

Decisions, Inputs, and General Strategies

(Page 3 of 3 )

\begin{tabular}{|c|c|c|c|c|}
\hline Decision & Input & Existing Data & Data Gap & Strategy \\
\hline \multirow{3}{*}{$\begin{array}{l}\text { Are data sufficient to } \\
\text { support closure options? }\end{array}$} & No further action & $\begin{array}{l}\text { Historical evidence that contaminants } \\
\text { were released to the environment at the } \\
\text { four CASs }\end{array}$ & $\begin{array}{l}\text { Insufficient evidence from the four } \\
\text { CASs to proceed without } \\
\text { investigation } \\
\text { Presence, concentration, and } \\
\text { extent of COPCs at CASs }\end{array}$ & $\begin{array}{l}\text { Collect field and laboratory samples a } \\
\text { the four CASs and compare results to } \\
\text { FSLs and PALs, respectively; if no } \\
\text { COPCs are above PALs, prepare } \\
\text { CADD/Closure Report }\end{array}$ \\
\hline & Closure in place & $\begin{array}{l}\text { Assume industrial soil PRG per } \\
\text { NAC 445A (NAC, 1999); assume } 100 \\
\text { ppm for TPH per NAC 445A; assume } \\
\text { radionuclide concentrations are in the } \\
\text { range of background concentrations }\end{array}$ & $\begin{array}{l}\text { Presence of regulated COPCs } \\
\text { Concentrations above PALs }\end{array}$ & \multirow{2}{*}{$\begin{array}{l}\text { Collect field and laboratory samples } \\
\text { and compare results to FSLs and } \\
\text { PALs, respectively; if no COPCs are } \\
\text { above PALs, prepare CADD/Closure } \\
\text { Report; otherwise prepare CADD }\end{array}$} \\
\hline & \begin{tabular}{|l|} 
Clean closure by \\
contaminant removal
\end{tabular} & $\begin{array}{l}\text { Assume industrial soil PRG per } \\
\text { NAC 445A (NAC, 1999); assume } 100 \\
\text { ppm for TPH per NAC 445A; assume } \\
\text { radionuclide concentrations are in the } \\
\text { range of background concentrations }\end{array}$ & $\begin{array}{l}\text { Presence, concentration, and } \\
\text { extent of COPCs } \\
\text { Volume of contaminated material } \\
\text { above PALs }\end{array}$ & \\
\hline
\end{tabular}




\section{A.5.0 Investigation Strategy}

Systematic or gridded and biased surface and/or subsurface soil sampling will be conducted during the field investigation to determine the presence and the extent of COPCs and whether concentrations exceed PALs for the site. Additional samples may be collected for waste management characterization and disposal purposes. Direct push and hand auguring will be the primary investigation techniques for this CAU. Visual inspection, video surveys, and/or electromagnetic surveys will be conducted to investigate the drainpipes associated with CAS 03-09-06, Mud Disposal Crater, and CAS 03-47-02, Mud Plant Pond.

At CASs 03-09-07 and 03-09-06, an attempt will be made to collect three samples from each sample location for laboratory analysis. At each location, a sample of the mud will be collected, if sufficient volume is present. A second sample will be collected at the mud/native soil interface. A third sample will be collected below the interface. Additional samples will be collected, if necessary, until two consecutive "clean" intervals (i.e., FSRs are lower than FSLs) are sampled below the mud. In addition, the sample collected from the first of two consecutive "clean" intervals will be submitted for analysis. Field-screening methods and field-screening levels are presented in Tables A.3-1 through A.3-4. Samples will be analyzed for COPCs identified in Section 3.0 of the CAIP in accordance with the requirements in Appendix C.

Environmental soil samples will be field screened to guide additional sampling (as appropriate) to guide sample selection for laboratory analysis, to assist in waste management decisions, and to provide health and safety measures. All samples will be field screened for VOCs using a photoionization detector and radioactivity using an Electra alpha/beta scintillator or equivalent.

\section{A.5.1 CAS 03-09-07, Mud Pit}

A minimum of two biased and nine gridded locations will be sampled. The biased locations include the "low spot" (based on visual inspection) of the large mud pit, and the "low spot" of the internal mud pit. Additional samples may be collected at the discretion of the Site Supervisor to adequately characterize the nature and extent of contamination. At each location, samples will be collected for analysis of the full suite of COPCs excluding PCBs. At some or all of the biased locations, based on the discretion of the Site Supervisor, samples will also be collected for PCB analysis. 
From each location, samples will be collected of the mud (if sufficient volume is present), at the mud/native soil interface and below the interface. Sampling will advance below the interface until FSRs at two consecutive intervals below the mud are less than FSLs.

\section{A.5.2 CAS 03-44-01, Chromium Contamination Spill}

The Chromium Contamination Spill, CAS 03-44-01, will be investigated using visual inspection and sample collection. Samples will be collected from the center of the 2- x 3-ft stained area. The vertical extent of the chromium contamination will be determined by sampling at the surface, at $1 \mathrm{ft}$ bgs, and then at 3-ft intervals. Sampling will advance until FSRs at two consecutive intervals are below FSLs. The lateral extent of contamination will be determined by performing 2-ft triangular step-outs from the center of the stained area. Step-outs will be collected from the center of the stained area and extending out into three directions (every direction except towards the southeastern wall of the Mud Plant Building, which is adjacent to the stain).

\section{A.5.3 CAS 03-47-02, Area 3 Mud Plant Pond}

The Mud Plant Pond will be investigated using direct-push and/or auguring techniques. Two biased locations will be sampled; one in the low spot in the pond, based on visual inspection, and another below the white discharge pipe. If no low spot is observed, this sample will be collected from along the southwest wall. Additional biased sample locations will be determined at the discretion of the Site Supervisor to adequately characterize the nature and extent of contamination. Nine gridded locations will also be sampled from within the Mud Plant Pond. From each location, samples will be collected of the mud, at the mud/native soil interface, and below the interface until FSRs at two consecutive intervals below the mud are less than FSLs.

\section{A.5.4 CAS 03-09-06, Mud Disposal Crater}

A minimum of three biased and nine gridded shallow subsurface soil and mud/native soil interface and below-interface soil samples will be collected to investigate the vertical and lateral extent of contamination in the Mud Disposal Crater. Biased sample locations will include underneath the discharge pipe, underneath the trough at base of concrete discharge pad, and at the low point in the crater as identified through visual identification, if access is possible. Additional locations will be determined at the discretion of the Site Supervisor, based on FSRs. At each location, samples will be collected for analysis of the full suite of COPCs excluding PCBs. At the biased locations located 
underneath the trough at the base of the concrete discharge pad, samples will also be collected for PCB analysis.

To investigate the vertical extent of contamination, samples will be collected above the mud/native soil interface, at the interface, and below the interface. Sampling will advance below the interface until FSRs at two consecutive intervals below the mud are less than FSLs.

The sampling strategy for this CAS is the utilization of direct-push techniques. The depth of the mud, and the geometries and contours of the crater are not fully known. If possible, a preliminary geophysical survey of the site will be performed utilizing GPR. In the event that due to both practicality and health and safety concerns the crater and/or mud is deemed unstable, sampling will occur using methods that allow for access to sample locations through appropriate weight distribution across the surface of the mud. 


\section{A.6.0 Decision Rules}

The following decision rules are applicable to this investigation and will be used to guide the investigation and subsequent data evaluation:

- If, in the course of the investigation, either of the following occur, then the investigation will be halted and rescoped, as necessary:

- The conceptual model fails to such a degree that rescoping is required.

- Sufficient data are collected to support evaluation of corrective actions.

- If field screening indicates no COPCs above FSLs at a prescribed sampling location, then a soil sample at the next prescribed sampling location will be field screened. If no COPCs are indicated, then a confirmatory laboratory sample will be submitted from the upper interval.

- If field screening indicates the presence of COPCs above FSLs, then the investigation will continue to determine the vertical and lateral extent of COPCs until FSRs are below FSLs; whereupon, a sample will be submitted for laboratory analysis to verify FSRs. Samples will be submitted for laboratory analysis from the subsurface interval that represents the highest FSR at the discretion of the Site Supervisor. Additional samples may be required for waste characterization and disposal purposes.

- If field screening indicates the presence of COPCs above FSLs for an analyte, samples will be submitted for laboratory analysis for that analyte at that sample location. If laboratory results indicate the presence of contaminants of concern above PALs, then a CADD will be prepared.

- If no COPCs are identified above PALs, then a CADD/Closure Report will be prepared according to the outline agreed upon by NDEP and DOE/NV. This type of CADD incorporates the elements of the CADD and closure report and serves as the closure report for the site.

- If analytical results are not adequate for preparation of a CADD, then additional step-out sampling may be conducted as a Stage II investigation. 


\section{A.7.0 Decision Error}

Biased and gridded sampling will be conducted at CAU 34 as identified in Section A.4.0, A.5.0, and A.6.0. Biased sampling is appropriate because the CASs are well defined and process knowledge and historical evidence indicate that contamination may have accumulated in biased locations. Process knowledge indicates that additional contamination, if any, is confined to the historical boundaries of the sites and random sampling locations will assist in determining the extent of this contamination.

Biased sampling strategy targets worst-case contamination by sampling the Mud Pit, the Chromium Contamination Spill, the Mud Plant Pond, and Mud Disposal Crater at locations with the highest potential for contamination. This sampling strategy will ensure that the vertical extent of the contamination has been adequately located, identified, and quantified. Planned sample intervals may be substituted with intervals that exhibit the highest contamination levels for that sample location based on visual observation or other field-screening techniques. At least one sample with FSRs below FSLs will be obtained from each boring to define the lower limit of soil contamination (if any). FSRs will be confirmed by off-site laboratory analysis for these samples.

All soil samples will be field screened for VOCs and radionuclides. Selected samples from each location, as described in Sections A.5.1 through A.5.4, will be sent for off-site laboratory analysis for the appropriate COPCs listed in Tables A.3-1 through A.3-4.

The systematic gridded sampling approach, combined with the biased sampling described above, will assure complete coverage of the potentially contaminated area. The number of samples required to characterize the site to a predetermined level of confidence will be calculated using Equation 8 from Chapter 9 of SW-846 (EPA, 1996), with a confidence level and acceptable sampling error agreed to by the DOE/NV and the NDEP. The use of this equation assumes that the contaminant is normally distributed in the medium to be sampled.

Equation 8 from Chapter 9 of SW-846 gives the number of samples required to determine the mean value of a give parameter to within a specified percent error, $\mathrm{e}_{\mathrm{r}}$, with a confidence limit of 90 percent, using an analytical method with a specified coefficient of variation (CV) as:

$$
\mathrm{n}=\left(\mathrm{t}_{0.90, \mathrm{n}-1} \mathrm{CV} / \mathrm{e}_{\mathrm{r}}\right)^{2}
$$


where " $t$ " is the one-tailed 90 percent Student's " $t$ " value for the appropriate number of degrees of freedom (n-1). This equation may be rearranged to give the percent error that may be expected by analyzing a specified number of samples using a method with a specified CV as:

$$
\mathrm{e}_{\mathrm{r}}=\mathrm{t}_{0.90, \mathrm{n}-1} \mathrm{CV} /(\mathrm{n})^{1 / 2}
$$

The coefficient of variation in the above equations refers to the variability of the specific parameter in the soil medium. Since this variability is unknown prior to sampling, the coefficient of variation of the analytical procedure may be used as a first approximation.

Each of the analytical methods to be performed on the samples from CAU 34 measures the concentrations of multiple analytes. Since the method precision varies with each analyte, it is appropriate for the purposes of this section of the DQOs to utilize an average coefficient of variation for each method. SW-846 cites the following soil CVs for the indicated procedure. The average CV for SW-846 is specified in Table A.7-1.

Table A.7-1

Average Coefficient of Variation (CV) for SW-846 Methods

\begin{tabular}{|c|l|c|}
\hline SW-846 Method & \multicolumn{1}{|c|}{ Parameter Measured } & $\%$ CV \\
\hline \hline 6010B & RCRA Metals (except mercury) & 21.3 \\
\hline $8260 \mathrm{~B}$ & VOCs & 7.5 \\
\hline $8270 \mathrm{C}$ & SVOCs & 9.1 \\
\hline 8015B Modified & Diesel & 10.6 \\
\hline
\end{tabular}

The following Table A.7-2 shows the expected percent error for the nine-location gridded sampling pattern:

Table A.7-2

Expected Percent Error with Gridded Sampling Pattern

\begin{tabular}{|c|c|c|c|c|}
\hline & $\begin{array}{c}\text { Metals } \\
\text { (except mercury) }\end{array}$ & VOCs & SVOCs & $\begin{array}{c}\text { TPH } \\
\text { (diesel-range organics) }\end{array}$ \\
\hline \hline $\mathrm{CV}, \%$ & 25 & 10 & 10 & 15 \\
\hline $\mathrm{n}$ & 9 & 9 & 9 & 9 \\
\hline $\mathrm{e}_{\mathrm{r}, \%}$ & 16 & 6.5 & 6.5 & 10 \\
\hline
\end{tabular}


A relative error of 10-20 percent from the true mean at a confidence limit of 90 percent is considered acceptable for planned removal and remedial response studies (EPA, 1989). Thus, the nine-sample grid pattern is satisfactory for this corrective action investigation. 


\section{A.8.0 References}

Bielawski, J.P., Reynolds Electrical \& Engineering Co., Inc. 1994. Memorandum to E.W. Kendall (REECo) entitled: “Area 3 Mud Plant Compliance Meeting," 12 July. Las Vegas, NV.

Bordelois, B., Science Applications International Corporation. 1998. Memo to R. Jackson (IT) entitled, "CAU 236, CAS 03-47-01, Sampling Report," 31 March. Las Vegas, NV.

Charleton, B., Bechtel Nevada. 2000. Record of telecon with K. Willse (IT) concerning the status of the Mud Plant Building, 12 October. Las Vegas, NV.

DOE, see U.S. Department of Energy.

DOE/NV, see U.S. Department of Energy, Nevada Operations Office.

DRI, see Desert Research Institute.

Desert Research Institute. 1996. Nevada Test Site Water-Supply Wells, DOE/NV/10845--86.

Prepared by D. Gillespie, D. Jonathan, and P. Seaber. Reno, NV: Water Resources Center.

EPA, see U.S. Environmental Protection Agency.

Forsgren, F.M., HSI Geotrans. 1998. Memo to R. Jackson (IT) entitled, "CAU 34, CAS 03-47-02, Sampling Report," 27 March. Las Vegas, NV.

H\&N, see Holmes and Narver, Inc.

IT, see IT Corporation.

IT Corporation. 1998. CAU 34, CAS 03-09-07, Radiological Survey Results. Las Vegas, NV.

IT Corporation. 2000. CAU 34 Project Files, Field Activity Daily Log, 04 December. Las Vegas, NV.

LANL, see Los Alamos National Laboratory.

Los Alamos National Laboratory. 1991. Survey of Hazardous Materials Used in Nuclear Testing. Prepared by Ernest A. Bryant and J. Fabryka-Martin. Los Alamos, NM.

Myers and Nordeson, U.S. Geological Survey. 1962. Evaporation from the 17 Western States, with a Section on Evaporation Rates. Reston, VA: U.S. Department of the Interior.

NAC, see Nevada Administrative Code. 
Nevada Administrative Code. 1999. NAC 445A.2272, "Contamination of Soil: Establishment of Action Levels." Carson City, NV: Nevada Division of Environmental Protection.

REECo, see Reynolds Electrical \& Engineering Co., Inc.

RSN, see Raytheon Services Nevada.

Raytheon Services Nevada. 1991. Nevada Test Site Drilling \& Mining Summary. Prepared by M. Bennett. Las Vegas, NV.

Reynolds Electrical \& Engineering Co., Inc. 1992. RCRA Part B Permit Application for Waste Management Activities at the Nevada Test Site, Section L. Las Vegas, NV.

Reynolds Electrical \& Engineering Co., Inc. 1994a. Area 3 Waste Impoundment, Historical Information. Prepared by C.G. Postle. Las Vegas, NV.

Reynolds Electrical \& Engineering Co., Inc. 1994b. Area 3 Mud Plant Sampling Plan, Activities and Analytical Results 1994. Las Vegas, NV.

Rowe, P., Stone and Webster Engineering. 2000. Record of telecon with J. Markowsky (SAIC) concerning Area 3 Mud Disposal Crater, 18 December. Las Vegas, NV.

U.S. Department of Energy. 1988. Environmental Survey Preliminary Report, Nevada Test Site, Mercury, Nevada, April. Washington, DC: Environment, Safety and Health, Office of Environmental Audit.

U.S. Department of Energy, Nevada Operations Office. 1988. Washington, DC: Environment, Safety and Health Office of Environmental Audit, Environmental Survey Preliminary Report, DOE/NV--604. Las Vegas, NV.

U.S. Department of Energy, Nevada Operations Office. 1990. Environmental Survey Action Plan, Nevada Test Site, Mercury, Nevada, March. Las Vegas, NV.

U.S. Department of Energy, Nevada Operations Office. 1996. Industrial Sites Quality Assurance Project Plan, DOE/NV--372. Las Vegas, NV.

U.S. Department of Energy, Nevada Operations Office. 1997. Corrective Action Investigation Plan for Central Nevada Test Area CAU 417, Section L. Las Vegas, NV.

U.S. Department of Energy, Nevada Operations Office. 2000a. Nevada Test Site Resource Management Plan Annual Summary, DOE/NV--604. Las Vegas, NV.

U.S. Department of Energy, Nevada Operations Office. 2000b. United States Nuclear Tests, July 1945-September 1992, Rev. 15. Las Vegas, NV. 
U.S. Environmental Protection Agency. 1989. Soil Sampling Quality Assurance User's Guide, Second Edition, EPA/600/8-89/046. Washington, DC.

U.S. Environmental Protection Agency. 1996. Test Methods for Evaluating Solid Waste, Physical/Chemical Methods, SW-846, Third Edition, CD ROM, PB97-501928GEI (CD-ROM includes revisions to 1986, 1992, and 1994). Washington, DC.

U.S. Environmental Protection Agency. 2000. Memorandum from S.J. Smucker to PRG table users regarding Region 9 PRGs, 1 November. San Francisco, CA.

van Drielen, H., Nevada Division of Environmental Protection. 1994. Letter to Donald R. Elle (DOE) entitled, "Area 3, Mud Plant," 27 March. Las Vegas, NV: Department of Conservation and Natural Resources.

Witt, J., U.S. Department of Energy, Nevada Operations Office. 2000a. Record of telecon with K. Willse (IT) concerning the disposal use of the U3ag crater, 19 October. Las Vegas, NV.

Witt, J., U.S. Department of Energy, Nevada Operations Office. 2000b. Record of telecon with K. Willse (IT) concerning the Mud Plant Pond, 19 October. Las Vegas, NV. 


\section{Appendix B}

\section{Project Organization}




\section{B.1.0 Project Organization}

The DOE/NV Industrial Sites Project Manager is Janet Appenzeller-Wing and her telephone number is (702) 295-0461. The DOE/NV Industrial Sites Task Manager is Sabine Curtis and her telephone number is (702) 295-0542.

The names of the project Health and Safety Officer and the Quality Assurance Officer can be found in the appropriate DOE/NV plan. However, personnel are subject to change, and it is suggested that the DOE/NV Industrial Sites Project Manager be contacted for further information. The DOE/NV Task Manager will be identified in the FFACO Biweekly Activity Report prior to the start of field activities. 


\section{Appendix C}

Laboratory Chemical, Toxicity Characteristic Leaching Procedure, and Radiochemistry Analytical Requirements for Industrial Sites 
Table C.1-1

\section{Laboratory Chemical, Toxicity Characteristic Leaching Procedure, and Radiochemistry Analytical Requirements for Industrial Sites}

(Page 1 of 6)

\begin{tabular}{|c|c|c|c|c|c|c|}
\hline $\begin{array}{c}\text { Parameter or } \\
\text { Analyte }\end{array}$ & $\begin{array}{l}\text { Medium or } \\
\text { Matrix }\end{array}$ & $\begin{array}{l}\text { Analytical } \\
\text { Method }\end{array}$ & $\begin{array}{l}\text { Minimum } \\
\text { Reporting Limit }\end{array}$ & $\begin{array}{l}\text { Regulatory } \\
\text { Limit }\end{array}$ & $\begin{array}{c}\text { Relative } \\
\text { Percent } \\
\text { Difference } \\
\text { (RPD) }^{\mathrm{a}} \\
\end{array}$ & $\begin{array}{c}\text { Percent } \\
\text { Recovery } \\
(\% R)^{\mathrm{b}}\end{array}$ \\
\hline \multicolumn{7}{|c|}{ ORGANICS } \\
\hline \multirow{2}{*}{$\begin{array}{l}\text { Total Volatile } \\
\text { Organic Compounds } \\
\text { (VOCs) }\end{array}$} & Water & \multirow{2}{*}{$8260 B^{c}$} & \multirow{2}{*}{$\begin{array}{l}\text { Analyte-specific } \\
\text { estimated } \\
\text { quantitation limits }^{d}\end{array}$} & \multirow{2}{*}{$\begin{array}{c}\text { Not Applicable } \\
\text { (NA) }\end{array}$} & $14^{\mathrm{e}}$ & $61-145^{e}$ \\
\hline & Soil & & & & $24^{\mathrm{e}}$ & $59-172^{e}$ \\
\hline \multicolumn{7}{|l|}{$\begin{array}{c}\text { Toxicity } \\
\text { Characteristic } \\
\text { Leaching Procedure } \\
\text { (TCLP) VOCs }\end{array}$} \\
\hline Benzene & \multirow{10}{*}{ Aqueous } & \multirow{10}{*}{$1311 / 8260 \mathrm{~B}^{\mathrm{c}}$} & $0.050 \mathrm{mg} / \mathrm{L}^{d}$ & $0.5 \mathrm{mg} / \mathrm{L}^{\mathrm{d}}$ & \multirow{10}{*}{$14^{\mathrm{e}}$} & \multirow{10}{*}{$61-145^{e}$} \\
\hline $\begin{array}{c}\text { Carbon } \\
\text { Tetrachloride }\end{array}$ & & & $0.050 \mathrm{mg} / \mathrm{L}^{d}$ & $0.5 \mathrm{mg} / \mathrm{L}^{\mathrm{d}}$ & & \\
\hline Chlorobenzene & & & $0.050 \mathrm{mg} / \mathrm{L}^{\mathrm{d}}$ & $100 \mathrm{mg} / \mathrm{L}^{\mathrm{d}}$ & & \\
\hline Chloroform & & & $0.050 \mathrm{mg} / \mathrm{L}^{\mathrm{d}}$ & $6 \mathrm{mg} / \mathrm{L}^{\mathrm{d}}$ & & \\
\hline 1,2-Dichloroethane & & & $0.050 \mathrm{mg} / \mathrm{L}^{d}$ & $0.5 \mathrm{mg} / \mathrm{L}^{\mathrm{d}}$ & & \\
\hline 1,1-Dichloroethene & & & $0.050 \mathrm{mg} / \mathrm{L}^{\mathrm{d}}$ & $0.7 \mathrm{mg} / \mathrm{L}^{\mathrm{d}}$ & & \\
\hline Methyl Ethyl Ketone & & & $0.050 \mathrm{mg} / \mathrm{L}^{d}$ & $200 \mathrm{mg} / \mathrm{L}^{\mathrm{d}}$ & & \\
\hline Tetrachloroethene & & & $0.050 \mathrm{mg} / \mathrm{L}^{d}$ & $0.7 \mathrm{mg} / \mathrm{L}^{\mathrm{d}}$ & & \\
\hline Trichloroethene & & & $0.050 \mathrm{mg} / \mathrm{L}^{\mathrm{d}}$ & $0.5 \mathrm{mg} / \mathrm{L}^{\mathrm{d}}$ & & \\
\hline Vinyl Chloride & & & $0.050 \mathrm{mg} / \mathrm{L}^{\mathrm{d}}$ & $0.2 \mathrm{mg} / \mathrm{L}^{\mathrm{d}}$ & & \\
\hline \multirow{2}{*}{$\begin{array}{c}\text { Total Semivolatile } \\
\text { Organic Compounds } \\
\text { (SVOCs) }\end{array}$} & Water & \multirow{2}{*}{$8270 C^{c}$} & \multirow{2}{*}{$\begin{array}{c}\text { Analyte-specific } \\
\text { estimated } \\
\text { quantitation limits }^{d}\end{array}$} & \multirow{2}{*}{ NA } & $50^{e}$ & $9-127^{e}$ \\
\hline & Soil & & & & $50^{\mathrm{e}}$ & $11-142^{\mathrm{e}}$ \\
\hline \multicolumn{7}{|l|}{ TCLP SVOCs } \\
\hline o-Cresol & \multirow{6}{*}{ Aqueous } & \multirow{6}{*}{$1311 / 8270 C^{c}$} & $0.10 \mathrm{mg} / \mathrm{L}^{\mathrm{d}}$ & $200 \mathrm{mg} / \mathrm{L}^{\mathrm{d}}$ & \multirow{6}{*}{$50^{e}$} & \multirow{6}{*}{$9-127^{e}$} \\
\hline m-Cresol & & & $0.10 \mathrm{mg} / \mathrm{L}^{d}$ & $200 \mathrm{mg} / \mathrm{L}^{\mathrm{d}}$ & & \\
\hline p-Cresol & & & $0.10 \mathrm{mg} / \mathrm{L}^{\mathrm{d}}$ & $200 \mathrm{mg} / \mathrm{L}^{\mathrm{d}}$ & & \\
\hline Cresol (total) & & & $0.30 \mathrm{mg} / \mathrm{L}^{\mathrm{d}}$ & $200 \mathrm{mg} / \mathrm{L}^{\mathrm{d}}$ & & \\
\hline $\begin{array}{l}\text { 1,4-Dichloro- } \\
\text { benzene }\end{array}$ & & & $0.10 \mathrm{mg} / \mathrm{L}^{\mathrm{d}}$ & $7.5 \mathrm{mg} / \mathrm{L}^{\mathrm{d}}$ & & \\
\hline 2,4-Dinitrotoluene & & & $0.10 \mathrm{mg} / \mathrm{L}^{\mathrm{d}}$ & $0.13 \mathrm{mg} / \mathrm{L}^{\mathrm{d}}$ & & \\
\hline
\end{tabular}


Table C.1-1

\section{Laboratory Chemical, Toxicity Characteristic Leaching Procedure, and Radiochemistry Analytical Requirements for Industrial Sites}

(Page 2 of 6)

\begin{tabular}{|c|c|c|c|c|c|c|}
\hline $\begin{array}{l}\text { Parameter or } \\
\text { Analyte }\end{array}$ & $\begin{array}{l}\text { Medium or } \\
\text { Matrix }\end{array}$ & $\begin{array}{l}\text { Analytical } \\
\text { Method }\end{array}$ & $\begin{array}{l}\text { Minimum } \\
\text { Reporting Limit }\end{array}$ & $\begin{array}{l}\text { Regulatory } \\
\text { Limit }\end{array}$ & $\begin{array}{c}\text { Relative } \\
\text { Percent } \\
\text { Difference } \\
\text { (RPD) }^{\mathrm{a}}\end{array}$ & $\begin{array}{c}\text { Percent } \\
\text { Recovery } \\
(\% R)^{b}\end{array}$ \\
\hline $\begin{array}{l}\text { Hexachloro- } \\
\text { benzene }\end{array}$ & \multirow{8}{*}{ Aqueous } & \multirow{8}{*}{$1311 / 8270 C^{c}$} & $0.10 \mathrm{mg} / \mathrm{L}^{\mathrm{d}}$ & $0.13 \mathrm{mg} / \mathrm{L}^{\mathrm{d}}$ & \multirow{8}{*}{$50^{e}$} & \multirow{8}{*}{$9-127^{e}$} \\
\hline $\begin{array}{l}\text { Hexachloro- } \\
\text { butadiene }\end{array}$ & & & $0.10 \mathrm{mg} / \mathrm{L}^{\mathrm{d}}$ & $0.5 \mathrm{mg} / \mathrm{L}^{\mathrm{d}}$ & & \\
\hline $\begin{array}{l}\text { Hexachloro- } \\
\text { ethane }\end{array}$ & & & $0.10 \mathrm{mg} / \mathrm{L}^{\mathrm{d}}$ & $3 \mathrm{mg} / \mathrm{L}^{\mathrm{d}}$ & & \\
\hline Nitrobenzene & & & $0.10 \mathrm{mg} / \mathrm{L}^{\mathrm{d}}$ & $2 \mathrm{mg} / \mathrm{L}^{\mathrm{d}}$ & & \\
\hline $\begin{array}{l}\text { Pentachloro- } \\
\text { phenol }\end{array}$ & & & $0.50 \mathrm{mg} / \mathrm{L}^{\mathrm{d}}$ & $100 \mathrm{mg} / \mathrm{L}^{\mathrm{d}}$ & & \\
\hline Pyridine & & & $0.10 \mathrm{mg} / \mathrm{L}^{\mathrm{d}}$ & $5 \mathrm{mg} / \mathrm{L}^{\mathrm{d}}$ & & \\
\hline $\begin{array}{l}\text { 2,4,5-Trichloro- } \\
\text { phenol }\end{array}$ & & & $0.10 \mathrm{mg} / \mathrm{L}^{\mathrm{d}}$ & $400 \mathrm{mg} / \mathrm{L}^{\mathrm{d}}$ & & \\
\hline $\begin{array}{c}\text { 2,4,6-Trichloro- } \\
\text { phenol }\end{array}$ & & & $0.10 \mathrm{mg} / \mathrm{L}^{\mathrm{d}}$ & $2 \mathrm{mg} / \mathrm{L}^{\mathrm{d}}$ & & \\
\hline \multirow{2}{*}{$\begin{array}{c}\text { Total } \\
\text { Pesticides }\end{array}$} & Water & \multirow{2}{*}{$8081 A^{c}$} & \multirow{2}{*}{$\begin{array}{l}\text { Analyte-specific } \\
(\mathrm{CRQL})^{\mathrm{e}}\end{array}$} & \multirow{2}{*}{ NA } & $27^{e}$ & $38-131^{e}$ \\
\hline & Soil & & & & $50^{e}$ & $23-139^{e}$ \\
\hline \multicolumn{7}{|l|}{$\begin{array}{c}\text { TCLP } \\
\text { Pesticides }\end{array}$} \\
\hline Chlordane & \multirow{7}{*}{ Aqueous } & \multirow{7}{*}{$1311 / 8081 A^{c}$} & $0.0005 \mathrm{mg} / \mathrm{L}^{\mathrm{e}}$ & $0.03 \mathrm{mg} / \mathrm{L}^{\mathrm{d}}$ & \multirow{7}{*}{$27^{e}$} & \multirow{7}{*}{$38-131^{e}$} \\
\hline Endrin & & & $0.001 \mathrm{mg} / \mathrm{L}^{\mathrm{e}}$ & $0.02 \mathrm{mg} / \mathrm{L}^{\mathrm{d}}$ & & \\
\hline Heptachlor & & & $0.0005 \mathrm{mg} / \mathrm{L}^{\mathrm{e}}$ & $0.008 \mathrm{mg} / \mathrm{L}^{\mathrm{d}}$ & & \\
\hline $\begin{array}{l}\text { Heptachlor } \\
\text { Epoxide }\end{array}$ & & & $0.0005 \mathrm{mg} / \mathrm{L}^{\mathrm{e}}$ & $0.008 \mathrm{mg} / \mathrm{L}^{\mathrm{d}}$ & & \\
\hline $\begin{array}{c}\text { gamma-BHC } \\
\text { (Lindane) }\end{array}$ & & & $0.0005 \mathrm{mg} / \mathrm{L}^{\mathrm{e}}$ & $0.4 \mathrm{mg} / \mathrm{L}^{\mathrm{d}}$ & & \\
\hline Methoxychlor & & & $0.005 \mathrm{mg} / \mathrm{L}^{\mathrm{e}}$ & $10 \mathrm{mg} / \mathrm{L}^{\mathrm{d}}$ & & \\
\hline Toxaphene & & & $0.05 \mathrm{mg} / \mathrm{L}^{\mathrm{e}}$ & $0.5 \mathrm{mg} / \mathrm{L}^{\mathrm{d}}$ & & \\
\hline \multirow[b]{2}{*}{$\begin{array}{l}\text { Polychlorinated } \\
\text { Biphenyls (PCBs) }\end{array}$} & Water & \multirow[b]{2}{*}{$8082^{c}$} & \multirow{2}{*}{$\begin{array}{c}\text { Analyte-specific } \\
\text { contract required } \\
\text { quantitation limits } \\
(\mathrm{CRQL})^{\mathrm{e}}\end{array}$} & \multirow[b]{2}{*}{ NA } & \multirow[b]{2}{*}{ Lab-specific ${ }^{f}$} & \multirow[b]{2}{*}{ Lab-specific $^{\dagger}$} \\
\hline & Soil & & & & & \\
\hline \multirow{2}{*}{$\begin{array}{c}\text { Total } \\
\text { Herbicides }\end{array}$} & Water & \multirow{2}{*}{$8151 A^{c}$} & $1.3 \mu \mathrm{g} / \mathrm{L}^{\mathrm{c}}$ & \multirow{2}{*}{ NA } & \multirow{2}{*}{ Lab-specific $^{\dagger}$} & \multirow{2}{*}{ Lab-specific $^{\dagger}$} \\
\hline & Soil & & $66 \mu \mathrm{g} / \mathrm{kg}^{\mathrm{c}}$ & & & \\
\hline \multicolumn{7}{|l|}{$\begin{array}{c}\text { TCLP } \\
\text { Herbicides }\end{array}$} \\
\hline $2,4-D$ & \multirow{2}{*}{ Aqueous } & \multirow{2}{*}{$1311 / 8151 A^{c}$} & $0.002 \mathrm{mg} / \mathrm{L}^{d}$ & $10 \mathrm{mg} / \mathrm{L}^{\mathrm{d}}$ & \multirow{2}{*}{ Lab-specific ${ }^{f}$} & \multirow{2}{*}{ Lab-specific $^{\dagger}$} \\
\hline $2,4,5-\mathrm{TP}$ & & & $0.00075 \mathrm{mg} / \mathrm{L}^{\mathrm{d}}$ & $1 \mathrm{mg} / \mathrm{L}^{\mathrm{d}}$ & & \\
\hline
\end{tabular}


Table C.1-1

Laboratory Chemical, Toxicity Characteristic Leaching Procedure, and Radiochemistry Analytical Requirements for Industrial Sites

(Page 3 of 6 )

\begin{tabular}{|c|c|c|c|c|c|c|}
\hline $\begin{array}{l}\text { Parameter or } \\
\text { Analyte }\end{array}$ & $\begin{array}{l}\text { Medium or } \\
\text { Matrix }\end{array}$ & $\begin{array}{l}\text { Analytical } \\
\text { Method }\end{array}$ & $\begin{array}{c}\text { Minimum } \\
\text { Reporting Limit }\end{array}$ & $\begin{array}{l}\text { Regulatory } \\
\text { Limit }\end{array}$ & $\begin{array}{c}\text { Relative } \\
\text { Percent } \\
\text { Difference } \\
\text { (RPD) }^{\mathrm{a}} \\
\end{array}$ & $\begin{array}{c}\text { Percent } \\
\text { Recovery } \\
(\% \mathrm{R})^{\mathrm{b}}\end{array}$ \\
\hline \multirow{4}{*}{$\begin{array}{c}\text { Total Petroleum } \\
\text { Hydrocarbons (TPH) }\end{array}$} & $\begin{array}{c}\text { Water } \\
\text { Gasoline }\end{array}$ & \multirow{4}{*}{ 8015B modified ${ }^{c}$} & $0.1 \mathrm{mg} / \mathrm{L}^{\mathrm{g}}$ & \multirow{4}{*}{ NA } & \multirow{4}{*}{ Lab-specific $^{\dagger}$} & \multirow{4}{*}{ Lab-specific $^{\dagger}$} \\
\hline & Soil Gasoline & & $0.5 \mathrm{mg} / \mathrm{kg}^{\mathrm{g}}$ & & & \\
\hline & Water Diesel & & $0.5 \mathrm{mg} / \mathrm{L}^{\mathrm{g}}$ & & & \\
\hline & Soil Diesel & & $25 \mathrm{mg} / \mathrm{kg}^{\mathrm{g}}$ & & & \\
\hline \multirow{2}{*}{ Explosives } & Water & \multirow{2}{*}{$8330^{c}$} & $14 \mu \mathrm{g} / \mathrm{L}^{\mathrm{c}}$ & \multirow{2}{*}{ NA } & \multirow{2}{*}{ Lab-specific ${ }^{\dagger}$} & \multirow{2}{*}{ Lab-specific $^{\dagger}$} \\
\hline & Soil & & $2.2 \mathrm{mg} / \mathrm{kg}^{\mathrm{c}}$ & & & \\
\hline \multirow{2}{*}{$\begin{array}{l}\text { Polychlorinated } \\
\text { Dioxins and Furans }\end{array}$} & Water & \multirow{2}{*}{$8280 \mathrm{~A} / 8290^{c}$} & $0.05 \mu \mathrm{g} / \mathrm{L}^{\mathrm{c}}$ & \multirow{2}{*}{ NA } & \multirow{2}{*}{ Lab-specific $^{\dagger}$} & \multirow{2}{*}{ Lab-specific $^{\dagger}$} \\
\hline & Soil & & $5 \mu \mathrm{g} / \mathrm{kg}^{\mathrm{c}}$ & & & \\
\hline \multicolumn{7}{|c|}{ INORGANICS } \\
\hline \multicolumn{7}{|l|}{$\begin{array}{c}\text { Total Resource } \\
\text { Conservation and } \\
\text { Recovery Act } \\
\text { (RCRA) Metals }\end{array}$} \\
\hline \multirow{2}{*}{ Arsenic } & Water & $6010 \mathrm{~B}^{\mathrm{c}}$ & $10 \mu \mathrm{g} / \mathrm{L}^{\mathrm{g}, \mathrm{h}}$ & \multirow{16}{*}{ NA } & \multirow{16}{*}{$20^{h}$} & \multirow{16}{*}{$75-125^{h}$} \\
\hline & Soil & $6010 \mathrm{~B}^{\mathrm{c}}$ & $1 \mathrm{mg} / \mathrm{kg}^{\mathrm{g}, \mathrm{h}}$ & & & \\
\hline \multirow{2}{*}{ Barium } & Water & $6010 \mathrm{~B}^{\mathrm{c}}$ & $200 \mu \mathrm{g} / \mathrm{L}^{\mathrm{g}, \mathrm{h}}$ & & & \\
\hline & Soil & $6010 \mathrm{~B}^{\mathrm{c}}$ & $20 \mathrm{mg} / \mathrm{kg}^{\mathrm{g}, \mathrm{h}}$ & & & \\
\hline \multirow{2}{*}{ Cadmium } & Water & $6010 \mathrm{~B}^{\mathrm{c}}$ & $5 \mu \mathrm{g} / \mathrm{L}^{\mathrm{g}, \mathrm{h}}$ & & & \\
\hline & Soil & $6010 \mathrm{~B}^{\mathrm{c}}$ & $0.5 \mathrm{mg} / \mathrm{kg}^{\mathrm{g}, \mathrm{h}}$ & & & \\
\hline \multirow{2}{*}{ Chromium } & Water & $6010 B^{c}$ & $10 \mu \mathrm{g} / \mathrm{L}^{\mathrm{g}, \mathrm{h}}$ & & & \\
\hline & Soil & $6010 \mathrm{~B}^{\mathrm{c}}$ & $1 \mathrm{mg} / \mathrm{kg}^{\mathrm{g}, \mathrm{h}}$ & & & \\
\hline \multirow{2}{*}{ Lead } & Water & $6010 \mathrm{~B}^{\mathrm{c}}$ & $3 \mu \mathrm{g} / \mathrm{L}^{\mathrm{g}, \mathrm{h}}$ & & & \\
\hline & Soil & $6010 B^{c}$ & $0.3 \mathrm{mg} / \mathrm{kg}^{\mathrm{g}, \mathrm{h}}$ & & & \\
\hline \multirow{2}{*}{ Mercury } & Water & $7470 A^{c}$ & $0.2 \mu \mathrm{g} / \mathrm{L}^{\mathrm{g}, \mathrm{h}}$ & & & \\
\hline & Soil & $7471 A^{c}$ & $0.1 \mathrm{mg} / \mathrm{kg}^{\mathrm{g}, \mathrm{h}}$ & & & \\
\hline \multirow{2}{*}{ Selenium } & Water & $6010 \mathrm{~B}^{\mathrm{c}}$ & $5 \mu \mathrm{g} / \mathrm{L}^{\mathrm{g}, \mathrm{h}}$ & & & \\
\hline & Soil & $6010 \mathrm{~B}^{\mathrm{c}}$ & $0.5 \mathrm{mg} / \mathrm{kg}^{\mathrm{g}, \mathrm{h}}$ & & & \\
\hline \multirow{2}{*}{ Silver } & Water & $6010 \mathrm{~B}^{\mathrm{c}}$ & $10 \mu \mathrm{g} / \mathrm{L}^{\mathrm{g}, \mathrm{h}}$ & & & \\
\hline & Soil & $6010 \mathrm{~B}^{\mathrm{c}}$ & $1 \mathrm{mg} / \mathrm{kg}^{\mathrm{g}, \mathrm{h}}$ & & & \\
\hline
\end{tabular}


Table C.1-1

Laboratory Chemical, Toxicity Characteristic Leaching Procedure, and Radiochemistry Analytical Requirements for Industrial Sites (Page 4 of 6 )

\begin{tabular}{|c|c|c|c|c|c|c|}
\hline $\begin{array}{l}\text { Parameter or } \\
\text { Analyte }\end{array}$ & $\begin{array}{l}\text { Medium or } \\
\text { Matrix }\end{array}$ & $\begin{array}{l}\text { Analytical } \\
\text { Method }\end{array}$ & $\begin{array}{c}\text { Minimum } \\
\text { Reporting Limit }\end{array}$ & $\begin{array}{l}\text { Regulatory } \\
\text { Limit }\end{array}$ & $\begin{array}{c}\text { Relative } \\
\text { Percent } \\
\text { Difference } \\
\text { (RPD) }^{\mathrm{a}}\end{array}$ & $\begin{array}{c}\text { Percent } \\
\text { Recovery } \\
(\% R)^{\mathrm{b}}\end{array}$ \\
\hline $\begin{array}{l}\text { TCLP RCRA } \\
\text { Metals }\end{array}$ & & & & & & \\
\hline Arsenic & \multirow{8}{*}{ Aqueous } & \multirow{8}{*}{$\begin{array}{l}1311 / 6010 B^{c} \\
1311 / 7470 A^{c}\end{array}$} & $0.10 \mathrm{mg} / \mathrm{L}^{\mathrm{g}, \mathrm{h}}$ & $5 \mathrm{mg} / \mathrm{L}^{\mathrm{d}}$ & \multirow{8}{*}{$20^{\mathrm{h}}$} & \multirow{8}{*}{$75-125^{\mathrm{h}}$} \\
\hline Barium & & & $2 \mathrm{mg} / \mathrm{L}^{\mathrm{g}, \mathrm{h}}$ & $100 \mathrm{mg} / \mathrm{L}^{\mathrm{d}}$ & & \\
\hline Cadmium & & & $0.05 \mathrm{mg} / \mathrm{L}^{\mathrm{g}, \mathrm{h}}$ & $1 \mathrm{mg} / \mathrm{L}^{\mathrm{d}}$ & & \\
\hline Chromium & & & $0.10 \mathrm{mg} / \mathrm{L}^{\mathrm{g}, \mathrm{h}}$ & $5 \mathrm{mg} / \mathrm{L}^{\mathrm{d}}$ & & \\
\hline Lead & & & $0.03 \mathrm{mg} / \mathrm{L}^{\mathrm{g}, \mathrm{h}}$ & $5 \mathrm{mg} / \mathrm{L}^{\mathrm{d}}$ & & \\
\hline Mercury & & & $0.002 \mathrm{mg} / \mathrm{L}^{\mathrm{g}, \mathrm{h}}$ & $0.2 \mathrm{mg} / \mathrm{L}^{\mathrm{d}}$ & & \\
\hline Selenium & & & $0.05 \mathrm{mg} / \mathrm{L}^{\mathrm{g}, \mathrm{h}}$ & $1 \mathrm{mg} / \mathrm{L}^{\mathrm{d}}$ & & \\
\hline Silver & & & $0.10 \mathrm{mg} / \mathrm{L}^{\mathrm{g}, \mathrm{h}}$ & $5 \mathrm{mg} / \mathrm{L}^{\mathrm{d}}$ & & \\
\hline \multirow{2}{*}{ Cyanide } & Water & \multirow{2}{*}{$9010 \mathrm{~B}^{\mathrm{c}}$} & $0.01 \mathrm{mg} / \mathrm{L}^{\mathrm{h}}$ & \multirow{2}{*}{ NA } & \multirow{2}{*}{$20^{\mathrm{h}}$} & \multirow{2}{*}{$75-125^{h}$} \\
\hline & Soil & & $1.0 \mathrm{mg} / \mathrm{kg}^{\mathrm{h}}$ & & & \\
\hline \multirow[b]{2}{*}{ Sulfide } & Water & \multirow[b]{2}{*}{$9030 \mathrm{~B} / 9034^{\mathrm{c}}$} & $0.4 \mathrm{mg} / \mathrm{L}^{\mathrm{c}}$ & \multirow[b]{2}{*}{ NA } & \multirow[b]{2}{*}{ Lab-specific $^{\dagger}$} & \multirow[b]{2}{*}{ Lab-specific } \\
\hline & $\begin{array}{c}\text { Soil or } \\
\text { Sediment }\end{array}$ & & $10 \mathrm{mg} / \mathrm{kg}^{\mathrm{g}}$ & & & \\
\hline \multirow{2}{*}{$\mathrm{pH} /$ Corrosivity } & Water & $9040 \mathrm{~B}^{\mathrm{c}}$ & \multirow{2}{*}{ NA } & $\mathrm{pH}>2^{\mathrm{i}}$ & \multirow{2}{*}{ Lab-specific ${ }^{\dagger}$} & \multirow{2}{*}{ Lab-specific } \\
\hline & Soil & $9045 C^{c}$ & & $\mathrm{pH}<12.5^{\mathrm{i}}$ & & \\
\hline \multirow[b]{2}{*}{ Ignitability } & Water & $1010^{c}$ & \multirow[b]{2}{*}{ NA } & $\begin{array}{l}\text { Flash Point } \\
<140^{\circ} \mathrm{F}^{\mathrm{d}}\end{array}$ & \multirow[b]{2}{*}{ NA } & \multirow[b]{2}{*}{ NA } \\
\hline & Soil & $1030^{c}$ & & $\begin{array}{c}\text { Burn Rate } \\
>2.2 \mathrm{~mm} / \mathrm{sec} \\
\text { nonmetals; } \\
>0.17 \mathrm{~mm} / \mathrm{sec} \\
\text { metals }\end{array}$ & & \\
\hline
\end{tabular}


Table C.1-1

Laboratory Chemical, Toxicity Characteristic Leaching Procedure, and Radiochemistry Analytical Requirements for Industrial Sites (Page 5 of 6 )

\begin{tabular}{|c|c|c|c|c|c|c|}
\hline $\begin{array}{l}\text { Parameter or } \\
\text { Analyte }\end{array}$ & $\begin{array}{l}\text { Medium or } \\
\text { Matrix }\end{array}$ & $\begin{array}{l}\text { Analytical } \\
\text { Method }\end{array}$ & $\begin{array}{c}\text { Minimum } \\
\text { Reporting Limit }\end{array}$ & $\begin{array}{l}\text { Regulatory } \\
\text { Limit }\end{array}$ & $\begin{array}{c}\text { Relative } \\
\text { Percent } \\
\text { Difference } \\
\text { (RPD) }^{\mathrm{a}} \\
\end{array}$ & $\begin{array}{c}\text { Percent } \\
\text { Recovery } \\
(\% R)^{\mathrm{b}}\end{array}$ \\
\hline \multicolumn{7}{|c|}{ RADIOCHEMISTRY } \\
\hline \multirow{2}{*}{$\begin{array}{l}\text { Gamma-Emitting } \\
\text { Radionuclides }\end{array}$} & Water & EPA $901.1^{\mathrm{j}}$ & \multirow{2}{*}{ Isotopic-specific } & \multirow{2}{*}{ NA } & 20 & \multirow{12}{*}{$\begin{array}{c}\text { Tracer Yield } \\
\text { 30-105 } \\
\text { Laboratory } \\
\text { Control } \\
\text { Sample Yield } \\
80-120\end{array}$} \\
\hline & Soil/Sediment & HASL $300^{k}$ & & & 35 & \\
\hline \multirow[b]{2}{*}{ Isotopic Plutonium } & Water & & $0.1 \mathrm{pCi} / \mathrm{g}$ & \multirow[b]{2}{*}{ NA } & 20 & \\
\hline & Soil/Sediment & NAS-NS-3058 ${ }^{\mathrm{m}, \mathrm{n}}$ & $\begin{array}{c}1 \mathrm{pCi} / \mathrm{L} \\
\mathrm{Pu}-238^{\circ} \\
0.4 \mathrm{pCi} / \mathrm{g} \\
\mathrm{Pu}-239 / 240^{\circ}\end{array}$ & & 35 & \\
\hline \multirow{2}{*}{ Isotopic Uranium } & Water & \multirow{2}{*}{ NAS-NS-3050 } & $2 \mathrm{pCi} / \mathrm{L}^{\mathrm{j}}$ & \multirow{2}{*}{ NA } & 20 & \\
\hline & Soil/Sediment & & $1 \mathrm{pCi} / \mathrm{g}$ & & 35 & \\
\hline \multirow{2}{*}{ Strontium - 90} & Water & SM 7500-Srr & $5 \mathrm{pCi} / \mathrm{L}$ & \multirow{2}{*}{ NA } & 20 & \\
\hline & Soil/Sediment & Martin $79^{s}$ & $1 \mathrm{pCi} / \mathrm{g}^{\mathrm{t}}$ & & 35 & \\
\hline \multirow{2}{*}{ Gross Alpha } & Water & EPA 900.0 & $3 \mathrm{pCi} / \mathrm{L}$ & \multirow{2}{*}{ NA } & 20 & \\
\hline & Soil/Sediment & SM $7110^{r}$ & $1 \mathrm{pCi} / \mathrm{g}$ & & 35 & \\
\hline \multirow{2}{*}{ Gross Beta } & Water & EPA 900.0 & $4 \mathrm{pCi} / \mathrm{L}$ & \multirow{2}{*}{ NA } & 20 & \\
\hline & Soil/Sediment & SM $7110^{r}$ & $3 \mathrm{pCi} / \mathrm{g}$ & & 35 & \\
\hline
\end{tabular}




\section{Table C.1-1 \\ Laboratory Chemical, Toxicity Characteristic Leaching Procedure, and Radiochemistry Analytical Requirements for Industrial Sites (Page 6 of 6$)$}

${ }^{a} \mathrm{RPD}$ is used to calculate precision.

Precision is estimated from the relative percent difference of the concentrations measured for the matrix spike and matrix spike duplicate analyses of unspiked field samples, or field duplicates of unspiked samples. It is calculated by: RPD $=100 \times\left\{\left(\left|C_{1}-C_{2}\right|\right) /\left[\left(C_{1}+C_{2}\right) / 2\right]\right\}$, where $C_{1}=$ Concentration of the analyte in the first sample aliquot, $C_{2}=$ Concentration of the analyte in the second sample aliquot.

b\% $R$ is used to calculate accuracy.

Accuracy is assessed from the recovery of analytes spiked into a blank or sample matrix of interest, or from the recovery of surrogate compounds spiked into each sample. The recovery of each spiked analyte is calculated by: $\% R=100 x$ $\left(\mathrm{C}_{\mathrm{s}}-\mathrm{C}_{\mathrm{u}} / \mathrm{C}_{\mathrm{n}}\right)$, where $\mathrm{C}_{\mathrm{s}}=$ Concentration of the analyte in the spiked sample, $\mathrm{C}_{\mathrm{u}}=$ Concentration of the analyte in the unspiked sample, $\mathrm{C}_{\mathrm{n}}=$ Concentration increase that should result from spiking the sample

'U.S. Environmental Protection Agency (EPA), Test Methods for Evaluating Solid Waste, 3rd Edition, Parts 1-4, SW-846 (EPA, 1996)

dEstimated Quantitation Limit as given in SW-846 (EPA, 1996)

${ }^{\circ}$ EPA Contract Laboratory Program Statement of Work for Organic Analysis (EPA, 1988b; 1991; and 1994b)

${ }^{f}$ In-House Generated RPD and \%R Performance Criteria

It is necessary for laboratories to develop in-house performance criteria and compare them to those in the methods. The laboratory begins by analyzing 15-20 samples of each matrix and calculating the mean \%R for each analyte. The standard deviation (SD) of each \%R is then calculated, and the warning and control limits for each analyte are established at \pm 2 SD and \pm 3 SD from the mean, respectively. If the warning limit is exceeded during the analysis of any sample delivery group (SDG), the laboratory institutes corrective action to bring the analytical system back into control. If the control limit is exceeded, the sample results for that SDG are considered unacceptable. These limits are reviewed after every 20-30 field samples of the same matrix and are updated at least semiannually. The laboratory tracks trends in both performance and control limits by the use of control charts. The laboratory's compliance with these requirements is confirmed as part of an annual laboratory audit. Similar procedures are followed in order to generate acceptance criteria for precision measurements.

IIndustrial Sites Quality Assurance Project Plan (DOE/NV, 1996)

hEPA Contract Laboratory Program Statement of Work for Inorganic Analysis (EPA, 1988a; 1994a; and 1995)

'RCRA Regulations and Keyword Index, 1998 Edition

'Prescribed Procedures for Measurements of Radioactivity in Drinking Water (EPA, 1980) or equivalent method

${ }^{\mathrm{k}}$ Environmental Measurements Laboratory Procedures Manual, 28th Edition (DOE, 1997) or equivalent method

'Isotope-Specific Minimum Reporting Limit to be specified in CAIP

${ }^{\mathrm{m}}$ The Radiochemistry of Plutonium (Coleman, 1965) or equivalent method

${ }^{n}$ Separation and Preconcentration of Actinides from Acidic Media by Extraction Chromatography (Horwitz, et al., 1992) or equivalent method.

- The Nevada Test Site Performance Objective Criteria requirement for certifying that hazardous waste has no added radioactivity requires that the total plutonium (the sum of the Pu-238, -239, -240 concentrations) not exceed $0.5 \mathrm{pCi} / \mathrm{g}$ (BN, 1995).

${ }^{\mathrm{P}}$ The Radiochemistry of Uranium (Grindler, 1962) or equivalent method

${ }^{\mathrm{q}}$ Separation and Preconcentration of Uranium from Acidic Media by Extraction Chromatography (Horwitz, et al., 1992) or equivalent method

'Standard Methods for Examination of Water and Waste Water (APHA, 1995) or equivalent

${ }^{s}$ Determination of Strontium-89 and -90 in soil with Total Sample Decomposition (Analytical Chemistry, 1979) or equivalent method

'The $1.0 \mathrm{pCi} / \mathrm{g}$ concentration is approximately twice the concentration of fallout Sr-90 in background surface soils reported in the Environmental Monitoring Report for the Proposed Ward Valley, California, Low-Level Radioactive Waste Facility (Atlan-Tech, 1992)

Definitions:

$\mu \mathrm{g} / \mathrm{kg}=$ Microgram(s) per kilogram $\mathrm{mg} / \mathrm{kg}=$ Milligram(s) per kilogram

$\mathrm{pCi} / \mathrm{L}=$ Picocurie(s) per liter $\mathrm{mg} / \mathrm{L}=$ Milligram(s) per liter

$\mathrm{pCi} / \mathrm{g}=$ Picocurie(s) per gram

$\mu \mathrm{g} / \mathrm{L}=$ Microgram(s) per liter 


\section{C.1.0 References}

APHA, see American Public Health Association.

American Public Health Association. 1995. Standard Methods for the Examination of Water and Waste Water, 19th Edition. Washington, DC.

Analytical Chemistry. 1979. Determination of Strontium-89, RCRA Regulations and Keyword Index, 1998, ISSN 1074-1364. New York, NY: Elsevier Science, Inc.

Atlan-Tech. 1992. Environmental Monitoring Report for the Proposed Ward Valley, California, Low-Level Radioactive Waste Facility. Roswell, GA.

BN, see Bechtel Nevada.

Bechtel Nevada. 1995. Nevada Test Site Performance Objective for Certification of Nonradioactive Hazardous Waste, Rev. 0, G-E11/96.01. Las Vegas, NV.

Coleman, G.H. 1965. The Radiochemistry of Plutonium, NAS-NS-3058. Washington, DC: National Academy of Science.

Grindler, J.E. 1962. The Radiochemistry of Uranium, NAS-NS3050. Washington, DC: National Academy of Science.

Horwitz E.P., M.L. Diets, R. Chiarizia, and H. Diamond. 1992. "Separation and Preconcentration of Uranium from Acidic Mesia by Extraction Chromatography." In Analyticda Chimica Acta, 281: 361-372. Amsterdam, The Netherlands: Elsevier Publishers, B.V.

RCRA Regulations and Keyword Index. 1998. ISSN 1074-1364. New York, NY: Elsevier Science, Inc.

U.S. Department of Energy. 1997. Environmental Measurements Laboratory Procedures Manual, HASL-300, 28th Edition, Vol. 1. New York, NY.

U.S. Department of Energy, Nevada Operations Office. 1996. Industrial Sites Quality Assurance Project Plan, Nevada Test Site, Nevada, DOE/NV--372. Las Vegas, NV.

U.S. Environmental Protection Agency. 1980. Prescribed Procedures for Measurements of Radioactivity in Drinking Water, EPA-600/4-79-020. Washington, DC. 
U.S. Environmental Protection Agency. 1988a. Contract Laboratory Program Statement of Work for Inorganic Analysis, SOW No. 788, EPA/540/R-94/093. Washington, DC.

U.S. Environmental Protection Agency. 1988b. Contract Laboratory Program Statement of Work for Organic Analysis, SOW No. 2/88, EPA/540/R-94//096. Washington, DC.

U.S. Environmental Protection Agency. 1991. Contract Laboratory Program Statement of Work for Organic Analysis, OLMO 1.8, EPA/540/R-94/078. Washington, DC.

U.S. Environmental Protection Agency. 1994a. Contract Laboratory Program Statement of Work for Inorganic Analysis, ILMO 3.0, EPA/540/R-94/076. Washington, DC.

U.S. Environmental Protection Agency. 1994b. Contract Laboratory Program Statement of Work for Organic Analysis, OLMO 3.1, EPA/540/R-94/073. Washington, DC.

U.S. Environmental Protection Agency. 1995. Contract Laboratory Program Statement of Work for Inorganic Analysis, ILMO 4.0, EPA/540/R-95/121. Washington, DC.

U.S. Environmental Protection Agency. 1996. Test Methods for Evaluating Solid Waste, Physical/Chemical Methods, SW-846, $3^{\text {rd }}$ Edition (which includes updates to 1986, 1992, and 1994 revisions), CD-ROM PB97-501928GEI. Washington, DC. 


\section{Appendix D}

\section{Comment Responses from NDEP}




\section{NEVADA ENVIRONMENTAL RESTORATION PROJECT}

\section{DOCUMENT REVIEW SHEET}

\begin{tabular}{|c|c|c|c|c|c|}
\hline \multicolumn{4}{|c|}{$\begin{array}{l}\text { 1. Document Title/Number: Draft Corrective Action Investigation Plan for Corrective Action Unit 34: Area } 3 \\
\text { Contaminated Waste Sites, Nevada Test Site, Nevada }\end{array}$} & \multicolumn{2}{|l|}{ 2. Document Date: January 2001} \\
\hline \multicolumn{4}{|c|}{ 3. Revision Number: 0} & \multicolumn{2}{|c|}{ 4. Originator/Organization: IT Corporation } \\
\hline \multicolumn{4}{|c|}{ 5. Responsible DOE/NV ERP Project Mgr.: Janet Appenzeller-Wing } & \multicolumn{2}{|c|}{ 6. Date Comments Due: February 26,2001} \\
\hline \multicolumn{6}{|c|}{ 7. Review Criteria: Full } \\
\hline \multicolumn{4}{|c|}{ 8. Reviewer/Organization/Phone No.: Ted Zaferatos, NDEP, 486-2856 } & \multicolumn{2}{|l|}{ 9. Reviewer's Signature: } \\
\hline $\begin{array}{l}\text { 10. Comment } \\
\text { Number/ } \\
\text { Location }\end{array}$ & 11. Type ${ }^{*}$ & 12. Comment & & 13. Comment Response & $\begin{array}{l}14 . \\
\text { Accept }\end{array}$ \\
\hline $\begin{array}{l}\text { 1) Executive } \\
\text { Summary, } \\
\text { Page ES-1, } \\
\text { Line } 13\end{array}$ & & $\begin{array}{l}\text { "...CAS 03-47-02, Chromium Contamination Spill..." The reference } \\
\text { should be to CAS 03-44-01, Chromium Contamination Spill. }\end{array}$ & $\begin{array}{l}\text { The reference } \\
\text { Chromium Col }\end{array}$ & $\begin{array}{l}\text { been changed to "CAS 03-44-01 } \\
\text { nination Spill" }\end{array}$ & Yes \\
\hline $\begin{array}{l}\text { 2) Executive } \\
\text { Summary, } \\
\text { Page ES-1, } \\
\text { Line } 17\end{array}$ & & $\begin{array}{l}\text { "...In the northwest corner of the mud pit is an internal bermed pit...". } \\
\text { The internal bermed pit is in the northeast corner of the mud pit. }\end{array}$ & $\begin{array}{l}\text { The sentence } \\
\text { corner of the } n \\
100 \text { by } 40 \mathrm{ft} \mathrm{in}\end{array}$ & $\begin{array}{l}\text { been changed to read, "In the northeast } \\
\text { pit is an internal bermed pit approximately } \\
\text { e." }\end{array}$ & Yes \\
\hline $\begin{array}{l}\text { 3) Section } 1.0 \\
\text { Introduction, } \\
\text { Page } 1 \text { of } 41\end{array}$ & & $\begin{array}{l}\text { "...In the northwest corner of the mud pit is an internal bermed pit...". } \\
\text { The internal bermed pit is in the northeast corner of the mud pit. }\end{array}$ & $\begin{array}{l}\text { The sentence } \\
\text { corner of the } n \\
100 \text { by } 40 \mathrm{ft} \text { in }\end{array}$ & $\begin{array}{l}\text { been changed to read, "In the northeast } \\
\text { pit is an internal bermed pit approximately } \\
\text { e." }\end{array}$ & Yes \\
\hline $\begin{array}{l}\text { 4) Section } 3.2 \text {, } \\
\text { Contaminants of } \\
\text { Potential } \\
\text { Concern, } \\
\text { Page } 20 \text { of } 41\end{array}$ & & $\begin{array}{l}\text { Regarding CAS 03-44-01, Chromium Contamination Spill; Appendix } \\
\text { A of the Preliminary DQO suggested testing for VOCs, SVOCs, } \\
\text { RCRA metals, TPH (diesel-range organics) and radionuclides in } \\
\text { addition to Chromium. The suggestion was based upon the fact that } \\
\text { it is unknown which mud additives, in addition to Raykrome-400, } \\
\text { might have been stored outside of the mud plant building. } \\
\text { Appendix A and Section } 3.2 \text { of the Draft CAIP have eliminated } \\
\text { testing for all COPCs except for Total and TCLP Chromium. Testing } \\
\text { for the originally-suggested COPCs would be appropriate. }\end{array}$ & $\begin{array}{l}\text { The VOCs, SV } \\
\text { organics) have } \\
\text { document. Ad } \\
\text { paragraph of } S \\
\text { to read, "Chro } \\
\text { Chromium Co } \\
\text { have been add } \\
\text { A.3.2, "In addi } \\
\text { mud additives } \\
\text { Plant Building. } \\
\text { constituents of } \\
\text { RCRA metals, }\end{array}$ & $\begin{array}{l}\text { s, RCRA metals, and TPH (diesel-range } \\
\text { en added to Section } 3.2 \text { of the main } \\
\text { onally, the first sentence of the first } \\
\text { tion A.3.2 (Appendix A) has been modified } \\
\text { m is the primary COPC at CAS 03-44-01, } \\
\text { mination Spill." The following sentences } \\
\text { at the end of the first paragraph in Section } \\
\text { to Raykrome-400, it is unknown which } \\
\text { ght have been stored outside of the Mud } \\
\text { ee COPCs at this site include the known } \\
\text { ud additives including VOCs, SVOCs, } \\
\text { d TPH (i.e., diesel-range organics)." }\end{array}$ & Partial \\
\hline
\end{tabular}




\section{NEVADA ENVIRONMENTAL RESTORATION PROJECT}

\section{DOCUMENT REVIEW SHEET}

Document Title/Number: Draft Corrective Action Investigation Plan for Corrective Action Unit 34: Area 3 Contaminated

Waste Sites, Nevada Test Site, Nevada

Reviewer/Organization: Ted Zaferatos, NDEP, 486-2856

\begin{tabular}{|c|c|c|c|c|}
\hline $\begin{array}{l}\text { 10. Comment } \\
\text { Number/ } \\
\text { Location }\end{array}$ & 11. Type* & 12. Comment & 13. Comment Response & $\begin{array}{l}14 . \\
\text { Accept }\end{array}$ \\
\hline $\begin{array}{l}\text { 4) Section } 3.2 \text {, } \\
\text { Contaminants of } \\
\text { Potential } \\
\text { Concern, } \\
\text { Page } 20 \text { of } 41 \text { - } \\
\text { (Cont'd) }\end{array}$ & & & $\begin{array}{l}\text { A second bullet has been added to Section A.3.2 that reads, } \\
\text { "VOCs, SVOCs, TPH (i.e. diesel-range organics), and } \\
\text { RCRA metals based upon the potential that other mud } \\
\text { additives were stored outside of the Mud Plant Building." } \\
\text { These COPCs (VOCs, SVOCs, TPH [i.e., diesel-range } \\
\text { organics], RCRA Metals) have been added to Table A.3-2. } \\
\text { Radionuclides were not added to the list of COPCs for } \\
\text { CAS 03-44-01. Radionuclides are associated with post-shot } \\
\text { drilling activities. Process knowledge indicates that no } \\
\text { post-shot drilling activities were associated with } \\
\text { CAS 03-44-01. The COPCs at this site are associated with } \\
\text { constituents of mud additives and do not include } \\
\text { radionuclides. }\end{array}$ & Partial \\
\hline $\begin{array}{l}\text { 5) Section } 6.1 \text {, } \\
\text { Duration, } \\
\text { Page } 36 \text { of } 41\end{array}$ & & $\begin{array}{l}\text { The Final CAIP has a FFACO milestone deadline of July } 31,2001 \text { in } \\
\text { accordance with the December 1, } 2000 \text { letter from Paul } \\
\text { Liebendorfer to Runore Wycoff. The May } 8,2001 \text { date indicated in } \\
\text { the Draft CAIP should be changed to July } 31,2001 \text {. }\end{array}$ & $\begin{array}{l}\text { The date, May } 8,2001 \text {, has been changed to July } 31,2001 \\
\text { in the document. }\end{array}$ & Yes \\
\hline $\begin{array}{l}\text { 6) Appendix A, } \\
\text { Table A.3-3, } \\
\text { Page A.19 of } \\
\text { A-34 }\end{array}$ & & $\begin{array}{l}\text { A row should be added to the table to show radionuclide } \\
\text { parameters. The COPCs for CAS } 03-47-02 \text { include radionuclides } \\
\text { as indicated in Section } 3.2 \text { of the Draft CAIP. }\end{array}$ & $\begin{array}{l}\text { A row for radionuclide parameters has been added to } \\
\text { Table A.3-3. }\end{array}$ & Yes \\
\hline
\end{tabular}

a Comment Types: $M=$ Mandatory, $S$ = Suggested.

Return Document Review Sheets to DOE/NV Environmental Restoration Division, Attn: QAC, M/S 505. 


\section{Distribution}

* Provide copy in distribution of Rev. 0 and subsequent revisions if applicable. Copies of the approved revision only should be distributed to the others.

\section{Copies}

Paul J. Liebendorfer

2 (Controlled)*

State of Nevada

Bureau of Federal Facilities

Division of Environmental Protection

333 W. Nye Lane, Room 138

Carson City, NV 89706-0851

Michael McKinnon

State of Nevada

Bureau of Federal Facilities

Division of Environmental Protection

555 E. Washington, Suite 4300

Las Vegas, NV 89101

Sabrina Lawrence

1 (Controlled)*

Environmental Restoration Division

DOE/Nevada Operations Office

P.O. Box 98518, M/S 505

Las Vegas, NV 89193-8518

Janet Appenzeller-Wing

1 (Controlled)*

Environmental Restoration Division

1 (Uncontrolled)*

DOE/Nevada Operations Office

P.O. Box 98518, M/S 505

Las Vegas, NV 89193-8518

Sabine Curtis

1 (Uncontrolled)*

Environmental Restoration Division

DOE/Nevada Operations Office

P.O. Box 98518, M/S 505

Las Vegas, NV 89193-8518 
Wayne Johnson

1 (Uncontrolled)*

Bechtel Nevada

P.O. Box 98521, M/S NTS306

Las Vegas, NV 89193-8521

Tom Fitzmaurice

1 (Uncontrolled)*

Bechtel Nevada

P.O. Box 98521, M/S NTS306

Las Vegas, NV 89193-8521

IT Corporation Central Files

1 (Uncontrolled)*

P.O. Box 93838

Las Vegas, NV 89193

Jeff Johnson

1 (Uncontrolled)*

IT Corporation, Las Vegas

P.O. Box 93838

Las Vegas, NV 89193

Alex MacKinlay

IT Corporation, Las Vegas

1 (Uncontrolled)*

P.O. Box 93838

Las Vegas, NV 89193

Technical Information Resource Center

1 (Uncontrolled)

DOE/Nevada Operations Office

P.O. Box 98518, M/S 505

Las Vegas, NV 89193-8518

U.S. Department of Energy

1 (Uncontrolled, electronic copy)

Office of Scientific and Technical Information

P.O. Box 62

Oak Ridge, TN 37831

Manager, Southern Nevada FFACO

1 (Uncontrolled)

Public Reading Facility

1 (Controlled)

P.O. Box 98521, M/S NLV040

Las Vegas, NV 89193-852

Manager, Northern Nevada FFACO

1 (Uncontrolled)

Public Reading Facility

c/o Nevada State Library \& Archives

Carson City, NV 89701-4285 
FFACO Support Office

1 (Controlled)

IT Corporation

P.O. Box 93838

Las Vegas, NV 89193 